
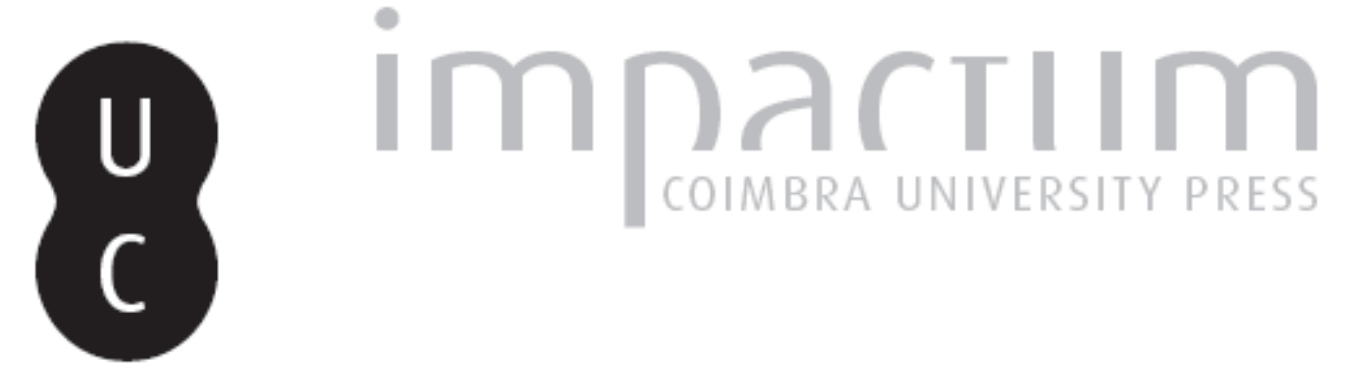

\title{
O grupo de Tumuli da Casinha Derribada (Conselho de Viseu): resultados preliminares da escavaçõa arqueológica dos monumentos 3, 4 e 5
}

Autor(es): $\quad$ Cruz, Domingos J.; Gomes, Luís Filipe C.; Carvalho, Pedro M. Sobral de

Publicado por: Imprensa da Universidade de Coimbra

URL

persistente:

URI:http://hdl.handle.net/10316.2/45403

DOI:

DOI:https://dx.doi.org/10.14195/1647-8657_37_1

Accessed : $\quad$ 26-Apr-2023 08:21:14

A navegação consulta e descarregamento dos títulos inseridos nas Bibliotecas Digitais UC Digitalis, UC Pombalina e UC Impactum, pressupõem a aceitação plena e sem reservas dos Termos e Condições de Uso destas Bibliotecas Digitais, disponíveis em https://digitalis.uc.pt/pt-pt/termos.

Conforme exposto nos referidos Termos e Condições de Uso, o descarregamento de títulos de acesso restrito requer uma licença válida de autorização devendo o utilizador aceder ao(s) documento(s) a partir de um endereço de IP da instituição detentora da supramencionada licença.

Ao utilizador é apenas permitido o descarregamento para uso pessoal, pelo que o emprego do(s) título(s) descarregado(s) para outro fim, designadamente comercial, carece de autorização do respetivo autor ou editor da obra.

Na medida em que todas as obras da UC Digitalis se encontram protegidas pelo Código do Direito de Autor e Direitos Conexos e demais legislação aplicável, toda a cópia, parcial ou total, deste documento, nos casos em que é legalmente admitida, deverá conter ou fazer-se acompanhar por este aviso.

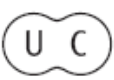


UNIVERSIDADE DE COIMBRA

FACULDADE DE LETRAS

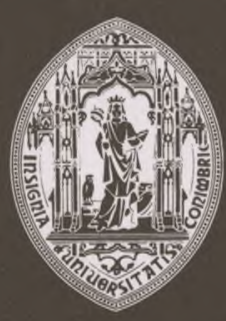

\section{CONIMBRIGA}

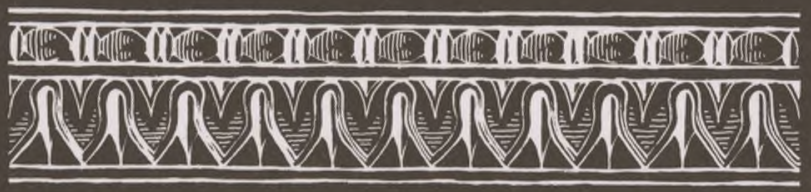

VOLUME XXXVII - 1998 
DOMINGOS J. CRUZ

Assistente da Faculdade de Letras de Coimbra

\section{LUÍS FILIPE C. GOMES}

Mestre em Arqueologia. Universidade do Porto

PEDRO M. SOBRAL DE CARVALHO

Mestre em Arqueologia. Universidade do Porto

O GRUPO DE TUMULI DA CASINHA DERRIBADA (CONCELHO DE VISEU). RESULTADOS PRELIMINARES DA ESCAVAÇÃO ARQUEOLÓGICA DOS MONUMENTOS 3, 4 e 5

"Conimbriga", XXXVII (1998), p. 5-76

Resumo: Publicam-se os resultados da escavação arqueológica feita nos monumentos 3, 4 e 5 da "Casinha Derribada".

Estes monumentos integram um grupo de cinco tumuli, externamente semelhantes mas evidenciando certa diversidade quanto às estruturas que encerram, dimensões, espólio, ritual, etc. Trata-se de pequenos montículos, de planta circular, volumetricamente pouco relevados no terreno, cobertos superficialmente por densa estrutura de pedras, predominantemente blocos de quartzo.

O conjunto ocupa a cumeada do relevo localmente designado "Monte Branco", ou "Penedos Brancos", na proximidade do vértice geodésico da "Casinha Derribada". Os monumentos 3 e 4 distanciam-se cerca de 8 metros (medidos a partir dos pontos centrais de cada um dos monumentos); o monumento cinco situa-se mais isolado mas proximamente; os monumentos 1 e 2 ocupam o ponto mais alto do relevo, mas também muito próximos um do outro; o monumento 1 é, por outro lado, volumetricamente mais expressivo.

Os monumentos 3 e 4 estavam intactos; o primeiro tinha na sua parte central uma fossa, de planta rectangular, aberta no substrato xisto-argiloso, medindo $0,60 \mathrm{~m}$ de comprimento, $0,40 \mathrm{~m}$ de largura e $0,24 / 26 \mathrm{~m}$ de profundidade; no seu interior foram colocados quatro vasos cerâmicos; não se identificaram

Conimbriga, 37 (1998), 5-76 
quaisquer vestígios orgânicos, a não ser um pequeno fragmento de carvão de madeira, integrado no seu interior acidentalmente; o encerramento da fossa foi feito com grande laje, de granito, insculturada, sobre e em tomo da qual se dispunham as terras e as pedras que constituíam o tumulus, perfazendo cerca de 4 metros de diâmetro; sobre a laje de fecho e nas terras adjacentes recolheram-se numerosas amostras de madeira carbonizada; admite-se a realização de uma fogueira, de carácter ritual, após o encerramento da fossa, directamente sobre a laje de cobertura. O monumento 4, externamente similar, continha, sensivelmente ao centro, uma pequena fossa, pouco profunda, de planta ovalada, preenchida com terra carbonosa e cinzas; trata-se de uma fogueira in situ, sobre a qual foi colocada terra e as pedras da cobertura superficial do tumulus. O monumento 5 é um "cairn", com uma cista na parte central, feita com quatro lajes fincadas, de granito, cujo conteúdo terá sido remexido.

As análises radiocarbónicas entretanto realizadas, feitas sobre amostras de carvão de madeira recolhidas no monumento 3, permitem definir o período de utilização desta estrutura, que se situará entre c. 1400 e 1150 a. C. Estes parâmetros cronológicos são, certamente, extensíveis ao monumento 4 , que lhe é muito próximo, para além da sua similitude externa, e certamente aos restantes.

As características das construções tumulares, a cultura material, as datações radiocarbónicas, etc., permitem uma aproximação à integração cultural deste grupo tumular no contexto regional e do Norte de Portugal e da Galiza. Admite-se que estes tumuli, como outros que têm sido localizados na região, se relacionem com as populações locais dos finais do Bronze médio / inícios do Bronze Final, vivendo dispersamente em pequenos casais, eventualmente anteriores à emergência dos povoados de altura da região. Por fim, a diversidade interna das estruturas, composição do espólio, ritual, etc., explicar-se-á no contexto da multiplicidade de gestos rituais que integram o cerimonial, diferenciado, de acordo com as circunstancias específicas de cada acto funerário-religioso, ou tão-só simbólico, de carácter social.

Abstract: Reference is made to the results of archaeological excavations on the monuments 3,4 and 5 of "Casinha Derribada".

These monuments are part of a group of 5 tumuli, externally similar but showing certain variations on the inner structures, dimensions, findings, rituals, etc. These are small tumuli of a circular shape, not too pronounced in the landscape and superficially covered by a thick lithic structure - mainly quartz blocks.

Conimbriga, 37 (1998), 5-76 
The complex occupies a mountain ridge known as "Monte Branco" or "Penedos Brancos", in the surroundings of the geodesic vertex of "Casinha Derribada".

Monuments 3 and 4 are about 8 meters apart from each other (from the central points of each monument); monument 5 is more isolated but is also within the same surroundings; monuments 1 and 2 take up the highest point of the crest and are also near one another; in the other hand, monument 1 is, volumetrically speaking, more expressive.

Monuments 3 and 4 were found intact; the first one had a rectangular pit in the centre, which had been opened over the schistose substrata, being $0,60 \mathrm{~m}$ long, 0,40 m wide and 0,24/0,26 m deep; four ceramic vases had been placed in its interior. We were unable to identify any organic traces, besides a small fragment of wood-charcoal accidentally integrated inside the pit; its closure was done through a large granite and engraved flagstone, over which (and around it) was displayed the soil and stones forming the tumulus in a diameter of about four meters; over this flagstone and on the adjoining soil, we collected countless samples of carbonized wood, presumably from a ritual fire made right over the flagstone after the closure of the pit. Monument 4 , which is similar on the outside, has an oval shaped small and shallow pit, about the centre, filled up with carbonous soil and ashes, caused by a fire in situ, over which was placed the soil and stones from the superficial cover of the tumulus. Monument 5 is a cairn with a pit at the centre made of four fixed granite flagstones. Its contents had already been disturbed.

The radiocarbon analyses of wood-charcoal from monument 3 , performed in the meantime, allow us to define the period of utilization of this structure, i.e., between 1400 and 1150 b. C. These chronological parameters are certainly extended to monument 4 (which is located nearby and is externally similar), as well as to the remaining monuments.

The characteristics of the burial constructions, the material culture, the radiocarbon dating, etc., indicate an approximation to a cultural integration among this tumular complex, within the regional context and of the North of Portugal and Galicia. It is believed that these tumuli, as well as others in the region, are linked with the local population of the latter part of the Middle Bronze/beginning of the Late Bronze Age, who lived in scattered farmsteads, perhaps before the arise of the hilltop settlements on the region. At last, the internal diversity of the structures, the composition of the findings, the rituals, etc., may be explained in the context of the multiple ritual forms of worshipping, varying according to specific circumstances of each religious burial act, or simply, of a social character.

Conimbriga, 37 (1998), 5-76 
(Página deixada propositadamente em branco) 


\section{O GRUPO DE TUMULI DA "CASINHA DERRIBADA" (CONCELHO DE VISEU) RESULTADOS PRELIMINARES DA ESCAVAÇÃO ARQUEOLÓGICA DOS MONUMENTOS 3, 4 e 5}

\section{Introdução}

É conhecida a importância arqueológica da região da Beira Alta. Destacam-se os vestígios pré-históricos, seja o elevado número de monumentos megalíticos, ou os sítios com indícios de ocupação, datando, pelo menos, do período Calcolitico; os povoados de altura do Bronze Final têm importância acrescida no contexto da pré-história do Noroeste peninsular (').

Os últimos anos registaram, por outro lado, uma intensificação da investigação arqueológica na região, desenvolvida por diferentes equipas, actuando em estações e âmbito cronológico diferenciados. Não são, no entanto, bem conhecidas as práticas funerárias e/ou cultuais da Idade do Bronze, particularmente da sua fase final, situação que é extensível ao Noroeste peninsular.

De facto, na Beira Alta, para além das possíveis reutilizações de construções dolménicas muito anteriores, apenas se conhecia até há pouco a "Necrópole de Paranho" (Molelos, Tondela) — grupo de 6 cistas inseridas num semicírculo de pedras fincadas com 5 metros de diâmetro —, estudada por José Coelho [1925] e, mais recentemente, a cista da "Fonte da Malga", escavada por Philine Kalb e Martin Höck, que forneceu fragmentos de uma possível "urna”, que estes

(') Vide Kalb, 1980.

Conimbriga, 37 (1998), 5-76 
investigadores dataram do século Vili a. C. [Kalb e Hock 1979] (2).

Conhecem-se, no entanto, vários povoados deste período genérico, muitos deles correspondendo, aparentemente, a uma ocupação prolongada. Os vestígios da cultura material, tipos de construção, implantação topográfica, distribuição geográfica de artefactos, permitem a definição de territórios de influência, por vezes de grande amplitude, bem como a abordagem de aspectos da economia e organização sociopolítica destas populações $\left({ }^{3}\right)$.

Em trabalhos recentes de prospecção foi possível a identificação na região da Beira Alta de vários grupos de monumentos, de pequenas dimensões, em pedra, de planta circular, pouco destacados no terreno, em alguns dos quais é possível observar na sua parte central pequenas cistas feitas com lajes de granito - "Casinha Derribada" e "Serra da Muna", no concelho de Viseu, "Mazugueira" e "Caramêlo", no concelho de Tondela, "Senhora da Ouvida", no concelho de Castro Daire, "Casa da Raposa", no concelho de Vila Nova de Paiva - eventualmente datáveis dos finais da Idade do Bronze $\left(^{4}\right)$.

Além do grande interesse científico destas construções tumulares, acrescia o facto de se implantarem em áreas cuja vegetação tinha sido destruída pela acção do fogo - o que permitiu a sua identificação -, prevendo-se, a breve trecho, acções de reflorestação, danificando-as. Era, por isso, urgente a preservação, quando tal fosse possível, dos próprios monumentos, ou, pelo menos, da informação científica que ainda pudessem fornecer.

Neste contexto, em 1992 é elaborado no Centro de Estudos

(2) Ao longo deste texto utilizaremos sempre referenciações cronológicas em anos reais, resultantes da calibração das datações radiocarbónicas. Exceptuam-se as indicações temporais bibliograficamente identificadas, cujos parâmetros cronológicos são de carácter relativo, ou derivaram de resultados radiocarbónicos não calibrados a que se subtraiu o valor 1950 (ano convencional de Cabomo 14).

(3) Vide, sobretudo, Silva, 1986; Senna Martinez, 1989; Vaz, 1993; Pedro, 1995; Alarcão, 1993 e 1996 a.

$\left.{ }^{4}\right)$ De cada um destes grupos de monumentos foram elaboradas "memórias descritivas", no âmbito das actividades do Centro de Estudos Pré-históricos da Beira Alta: "Casinha Derribada" (1992), "Serra da Muna" (1993), "Caramêlo" e "Mazugueira" (1993), "Senhora da Ouvida" (1995), "Casa da Raposa" (1996), documentos enviados ao Instituto Português do Património Arquitectónico e Arqueológico (IPPAR), Autarquias e Direcção-Regional de Agricultura da Beira Litoral (Zona Agrária de Viseu). Rei. inéditos.

Conimbriga, 37 (1998), 5-76 
Pré-históricos da Beira Alta um projecto de investigação, cujo objectivo reside no estudo das práticas funerárias e cultuais dos finais da Idade do Bronze, a partir dos vestígios tumulares já identificados, mediante a realização de escavações arqueológicas, trabalhos de prospecção, com vista à detecção de outros e sua inventariação, estudo de materiais de antigas escavações e avulsos depositados em instituições museológicas, etc. $\left({ }^{5}\right)$.

Fundamentalmente importava conhecer as características tipológicas dos monumentos, sua articulação no grupo e entre as diferentes "necrópoles", a vigência cultural e cronológica, através do estudo comparado de estruturas, rituais funerários (ou cultuais), cultura material, etc., ou de datações obtidas pelo processo de Carbono 14, as "estratégias" que presidiram à sua implantação no terreno, bem como a relação com outros vestígios, sincrónicos ou não - outros monumentos tumulares, povoados, rochas insculturadas (que terão funcionado, muito provavelmente, como santuários, também significativos na região), etc. -, paralelamente ao conhecimento das condições naturais em que o homem deste período se inseriu - cobertura vegetal, variações climáticas, potencialidades agrológicas dos solos, etc. - no âmbito das diversas disciplinas da Paleoecologia, sempre que as condições de jazida o permitissem.

Neste texto apresentam-se os resultados preliminares das escavações arqueológicas realizadas em 1993 e 1994 nos monumentos

3,4 e 5 da "Casinha Derribada". Em tempo ulterior far-se-á uma avaliação mais aturada com outros dados de investigação que ainda decorre (análises pedológicas, radiocarbónicas, paleoambientais), acrescidos dos resultados da escavação dos restantes tumuli deste grupo.

Os trabalhos de escavação, dirigidos pelos autores, foram autorizados pelo Instituto Português do Património Arquitectónico e

$\left.{ }^{5}\right)$ O projecto foi apresentado ao Instituto Português do Património Arquitectónico e Arqueológico em Dezembro de 1992, integrando, inicialmente, D. J. Cruz, L. F. C. Gomes e P. M. S. Carvalho, sob coordenação do primeiro daqueles investigadores e orientação científica do Doutor J. de Alarcão, da Faculdade de Letras da Universidade de Coimbra. Presentemente participa também no projecto a Doutora Raquel Vilaça que, com um dos autores (DJC), dirigiu os trabalhos de escavação, em 1995, de alguns dos tumuli da "Senhora da Ouvida" (Castro Daire).

Conimbriga, 37 (1998), 5-76 
Arqueológico ( $\left.{ }^{6}\right)$. Tiveram o apoio financeiro desta instituição e da Câmara Municipal de Viseu, para além da colaboração em diversos aspectos de carácter logístico. A escavação dos monumentos 3 e 4 decorreu de 21 de Junho a 16 de Julho de 1993; a do monumento 5, de 13 de Junho a 2 de Julho de 1994.

A finalização em gabinete dos registos de campo, como também a tintagem dos vasos cerâmicos, foi executada pelo Dr. José Luís Madeira, do Instituto de Arqueologia da Faculdade de Letras de Coimbra. Os quatro vasos cerâmicos exumados no monumento 3 foram desenhados por A. Femando Barbosa, do Museu Regional de Arqueologia D. Diogo de Sousa, instituição que também procedeu à sua limpeza (sobretudo extracção de sais solúveis) e restauro $\left({ }^{7}\right)$.

\section{Os tumuli da "Casinha Derribada"}

Os monumentos da "Casinha Derribada" ${ }^{8}$ ) ocupam a cumeada
do "Monte Branco", também designado "Penedos Brancos"
- denominação popular que advém da abundância de quartzo nesta
área da serra do Mundão - - alinhados sensivelmente segundo a direcção
NO-SE; dispõem-se no terreno entre as cotas dos 660 e $670 \mathrm{~m}$,

$\left.{ }^{6}\right)$ Agradecemos a colaboração da Dr. ${ }^{a}$ Ana Isabel de Sá Ferreira Pipa, do Centro de Estudos Pré-históricos da Beira Alta. Participaram nestas duas campanhas vários jovens e estudantes universitários, estes últimos da Universidade Católica (Centro de Viseu), Universidade Portucalense "Infante D. Henrique" (Porto) e da Faculdade de Letras da Universidade de Lisboa, a quem também agradecemos.

(7) Expressamos à Dr. ${ }^{a}$ Isabel Cunha e Silva, Directora do Museu Regional de Arqueologia D. Diogo de Sousa, os nossos agradecimentos pelas facilidades e apoio prestado. Os referidos vasos foram depositados, a título precário e após autorização do Instituto Português do Património Arquitectónico e Arqueológico, no Museu de História Natural / Antropologia, da Faculdade de Ciências da Universidade do Porto. Por ocasião do Colóquio “A Pré-história na Beira Interior", que decorreu em Tondela de 21 a 23 de Novembro de 1997, estiveram expostos, com outra documentação gráfica, na mostra arqueológica então organizada, em cujo catálogo (Cfr. Vilaça, 1997) se publicou um pequeno texto sobre os monumentos 3 e 4 da "Casinha Derribada".

$\left.{ }^{8}\right)$ Incorrectamente grafada "Casinha Derrubada" na "Carta Militar de Portugal, na escala de 1/25.000", fl. 178 (Viseu), 2. ${ }^{\text {a } e d ., ~ 1987, ~ c o m o ~ t a m b e ́ m ~ n a ~ " C a r t a ~ C o r o g r a ̀ f i c a ~}$ de Portugal, na escala de 1/50.000", fl. 17-A (Viseu), 2.a ed., 1977.

Conimbriga, 37 (1998), 5-76 
constituindo o grupo de monumentos tumulares de idade pré-histórica situado a mais elevada altitude de todo o concelho de Viseu. Trata-se de área bastante restrita, visível nos 300 metros que separam os montículos mais periféricos (Fig. 1). Alguns, muito próximos, poderão constituir pequenos núcleos de duas unidades.

Os terrenos, nos limites das freguesias de Mundão e de Lordosa, não são acidentados, pertencendo à Administração Florestal de Viseu. A ocorrência em tempo recente de vários incêndios, destruindo a vegetação arbustiva então existente, permitiu a sua localização.

Administrativamente situam-se em área da freguesia do Mundão (a oeste do caminho carreteiro - limite das duas freguesias que atravessa a cumeada deste relevo).

$\mathrm{O}$ acesso faz-se a partir da estrada nacional que de Viseu se dirige a Castro Daire (E. N. n. ${ }^{\circ}$ 2) e desta, em Campo, pela via municipal (1345) que conduz ao Aérodromo "Gonçalves Lobato" e às povoações de Nelas e Cepões; nas imediações do aeródromo, é então necessário seguir para leste, inicialmente por estradão, depois por caminhos florestais, em percurso de pouco mais de 1,5 Km (Fig. 1).

Antes dos trabalhos arqueológicos, exceptuando o monumento 1, não eram evidentes sinais de remeximentos nem vestígios de estruturas internas, admitindo-se então que a maior parte se encontraria intacta $\left({ }^{9}\right)$.

$\mathrm{O}$ interesse arqueológico do sítio é referenciado, pela primeira vez, por Amorim Girão [1921-22], a propósito da existência de “[...] um antigo monumento megalítico destruído, sobre as ruínas do qual assenta ainda o marco geodésico" [p. 188], informação mais tarde repetida por

I. Moita [1966: 210].

Trata-se de um grupo de tumuli, de volumetria diferenciada, mas todos com uma cobertura pétrea densa, mostrando a coexistência de um monumento mais destacado, quer volumetricamente, quer topograficamente - Monumento 1 da Casinha Derribada -, com quatro outros de reduzidas dimensões e pouco perceptíveis no terreno, cada um dos quais, como revelaram os trabalhos de escavação arqueológica, contendo no seu interior diferentes estruturas.

$\left({ }^{9}\right)$ Cfr. "Monumentos da "Casinha Derribada" (conc. de Viseu): memória descritiva”, Viseu, CEPBA, 1992. Rei. inédito.

Conimbriga, 37 (1998), 5-76 


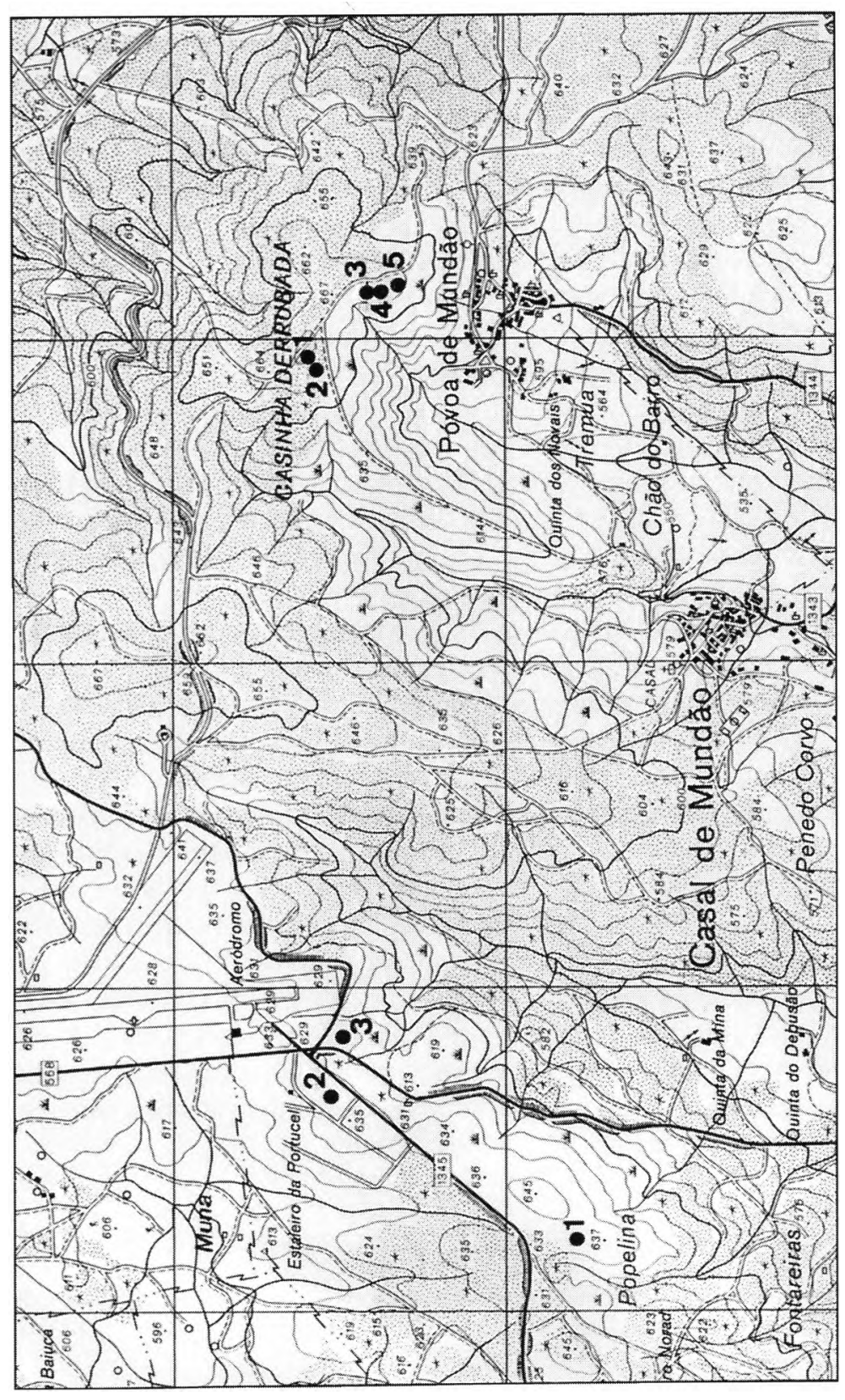

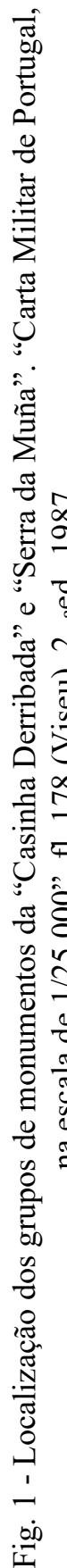


Monumento 1 - Tumulus de planta circular, medindo cerca de 13,30 metros de diâmetro e $1 \mathrm{~m}$ de altura. Densa cobertura pétrea, predominando os elementos de quartzo e algum xisto. Apresenta profunda cavidade na parte central e não são visíveis quaisquer elementos pétreos de grandes ou médias dimensões, eventualmente relacionáveis com qualquer estrutura pétrea que tenha sido implantada na sua parte central. Na periferia oeste foi erguido um marco geodésico - "Casinha Derribada" —, destruindo, neste sector, parte do tumulus. É a este tumulus que se refere A. Girão [1921-22: 188]. No conjunto é o mais mais monumental e dominante, ocupando o ponto mais elevado deste relevo. Localização: no referido lugar de "Monte Branco" ou "Penedos Brancos", como aliás todos os restantes, junto ao marco geodésico da "Casinha Derribada"; coord, geog.: lat. — 40 43' 10" norte; long. - 01 ${ }^{\circ} 16^{\prime} 04^{\prime}$ " (meridiano de Lisboa); alt. - 670 m ("Carta Militar de Portugal”, n. 178 (Viseu), 2. ed., 1987) (Fig. 1).

Monumento 2 -Tumulus de reduzidas dimensões, medindo cerca de $8,10 \mathrm{~m}$ de diâmetro e $0,15 \mathrm{~m}$ de altura, com densa cobertura pétrea, onde predominam os elementos de quartzo e algum xisto. Localização: a c. 8 metros para SO do monumento anterior; coord, geog.: lat. — 40 43' 09" norte; long. - $01^{\circ} 16^{\prime} 03^{\prime \prime}$; alt. $-670 \mathrm{~m}$.

Monumento 3 -Tumulus de reduzidas dimensões, medindo cerca de 4,5 m de diâmetro e cerca de $0,30 \mathrm{~m}$ de altura. Semelhante ao monumento anterior. Localização: a cerca de $250 \mathrm{~m}$ para SE do Monumento 1, à margem do caminho carreteiro que atravessa a cumeada do relevo e passa junto ao marco geodésico da "Casinha Derribada"; coord, geog.: lat. - 40 43' 03" norte; long. — $01^{\circ} 16^{\prime} 12^{\prime \prime}$; alt. — 666 m (Figs. 2 a 4).

Monumento 4 - Tumulus semelhante ao anterior, com 4,90 m de diâmetro e cerca de $0,35 \mathrm{~m}$ de altura. Localização: a $3,5 \mathrm{~m}$ para sul do monumento 3; coord, geog.: lat. — 40 43' 03" norte; long. — $01^{\circ} 16^{\prime} 12^{\prime \prime}$; alt. - 666 m (Figs. 2 a 4).

Monumento 5 - Semelhante aos monumentos 3 e 4, medindo 7,20 $\mathrm{m}$ de diâmetro e cerca de $0,80 \mathrm{~m}$ de altura. Implanta-se no limite de urna curva de nível, em superfície de encosta com declive bastante ligeiro (c. de 7\%), posição topográfica que lhe confere relativa dominância sobre a paisagem circundante $\left({ }^{10}\right)$. Localização: a cerca de $80 \mathrm{~m}$ para SSO do Monumento 4,

(10) De facto, e independentemente da "barreira" visual no sentido nascente resultante da sua localização no terreno, é possível observar não só todos os monumentos que constituem este grupo, como também o local de implantação do Monumento 1 da Serra da Muna, a cerca de 2,5 Km para OSO, e o vasto planalto que se espraia no sentido da capital beirã.

Conimbriga, 37 (1998), 5-76 


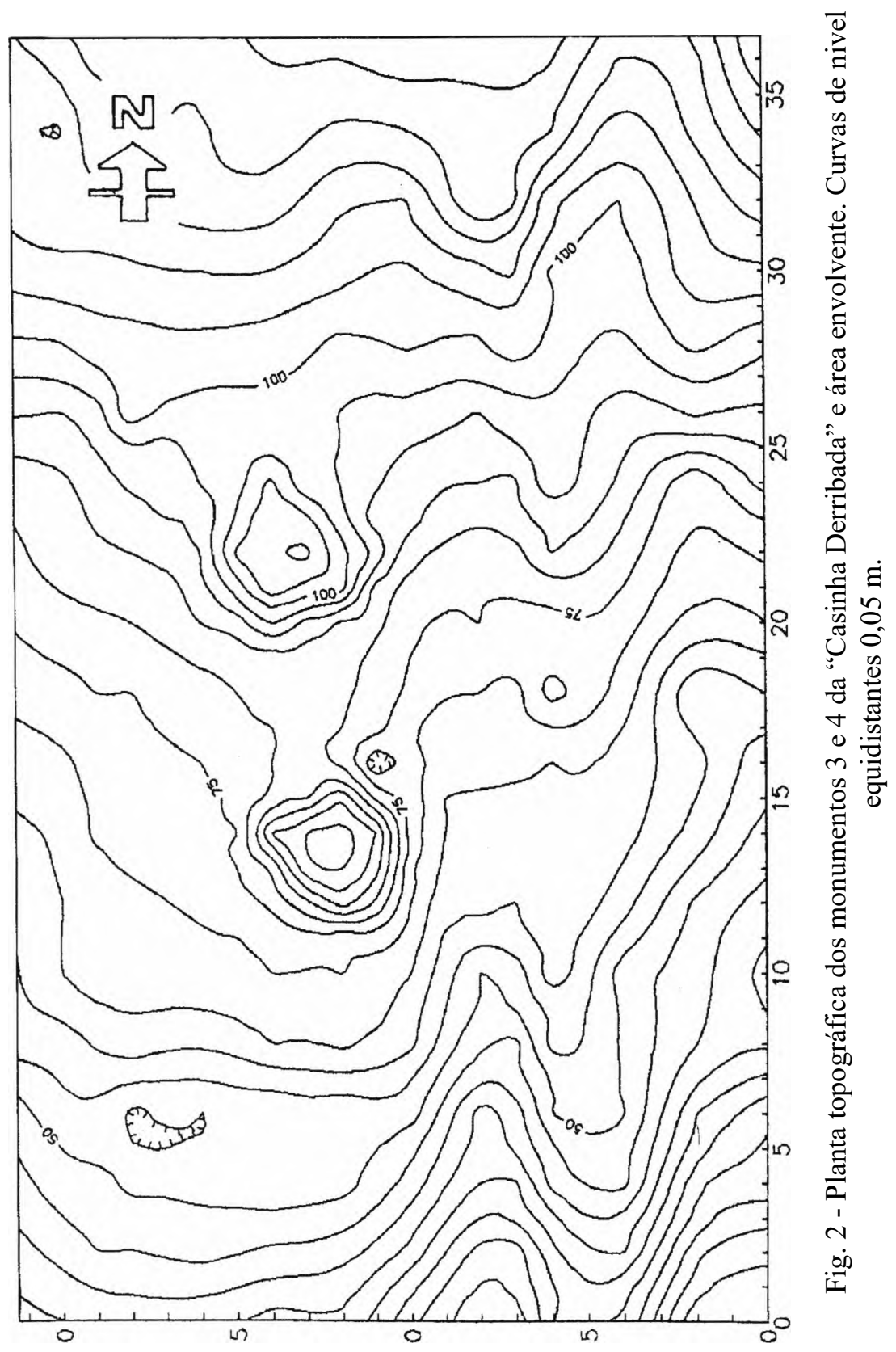


sensivelmente a 50 metros para oeste do caminho carreteiro atrás referido; coord, geog.: lat. $-40^{\circ} 43^{\prime} 01^{\prime \prime}$ norte; long. —01 $16^{\prime} 11^{\prime \prime}$; alt. — 660 m (Figs. 14 a 16).

\section{Contexto geomorfológico}

A nordeste da cidade de Viseu, a pouco mais de $8 \mathrm{~km}$ de distância, desenvolve-se um alinhamento de pequenos relevos, orientados segundo a direcção NO-SE, definidos pela curva de nível dos 600 metros; é encimado por plataformas limitadas, com uma ou outra saliência, aproveitadas para a implantação de marcos geodésicos, como o "Marco Grande" (660 m) e "Casinha Derribada" (670 m); similarmente, este bloco central prolonga-se para nordeste, com pontos mais elevados em "Alto do Facho" (650 m) e no "Alto de Passos" (656 m) - cuja cumeada é hoje atravessada pela estrada que de Viseu se dirige ao Sátão (n. ${ }^{\circ}$ 229) -, como para noroeste, com esporões a sul e a norte, definidores do "plateaux" que serviu para a implantação do aeródromo municipal, de que se destaca o alto da "Popelina" (643 m) e o "Penedo da Moura" $(610 \mathrm{~m}) ;$ o conjunto forma um relevo alongado, bordejando a margem sul do rio Vouga, constituindo, a leste do Sátão, um esporão da serra da Nave $\left({ }^{n}\right)$.

Trata-se de relevos arredondados, de encostas suaves e cimos aplanados, não acidentados; esta área do concelho de Viseu integra-se no "complexo xisto-grauváquico, de idade càmbrica e pré-câmbrica, com intercalações de conglomerados constituídos por elementos de quartzo e quartzito" [Ferreira, 1978: 16]. O substrato é xisto-argiloso, com aflorações frequentes de rochas filonianas, como o quartzo, por vezes com grande possança, como acontece na "Casinha Derribada". E uma área de contacto; os granitos, de idade hercínica, dominam a paisagem a sul destes relevos, como já acontece na "serra" da "Muna" (12).

Os outeiros de "Casinha Derribada", "Marco Grande", "Alto do Facho", etc., são sede de importantes linhas de água (Carvalhal e

(n) Vide Ferreira, 1978: 13-50; "Carta Corogràfica de Portugal, na escala de 1/50.000”, fl. 17-A (Viseu), 2. a ed., 1977; "Carta Militar de Portugal, na escala de 1/25.000”, fl. 178 (Viseu), 2. a ed., 1987; "Carta Geológica de Portugal, na escala de 1/500.000", Serviços Geológicos de Portugal, Lisboa, 1972.

${ }^{(12)}$ Em texto anexo desenvolvem-se anotações mais extensas sobre a geomorfologia deste sector do concelho de Viseu. Cfr. Simões, 1998, neste volume.

Conimbriga, 37 (1998), 5-76 


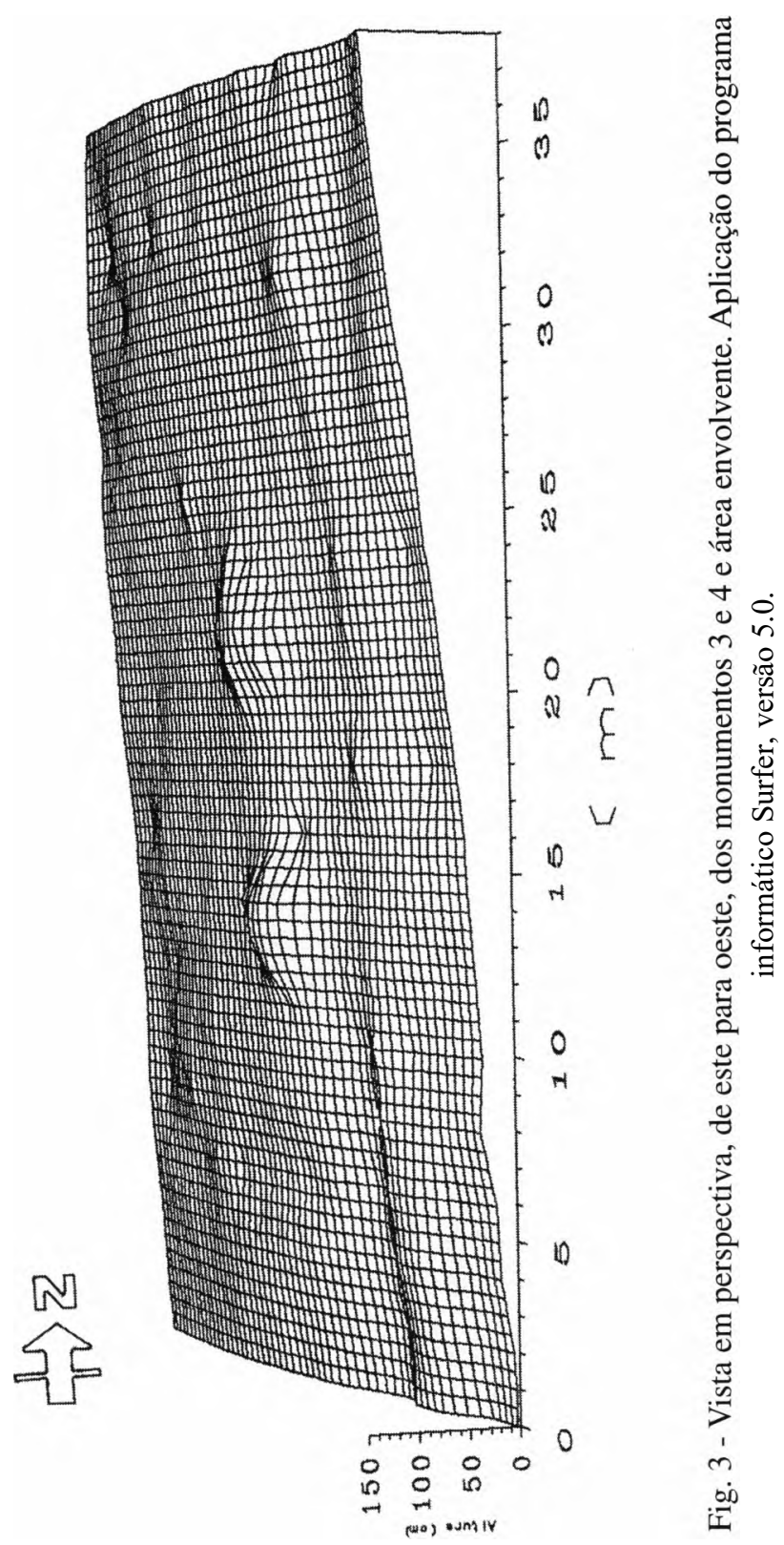



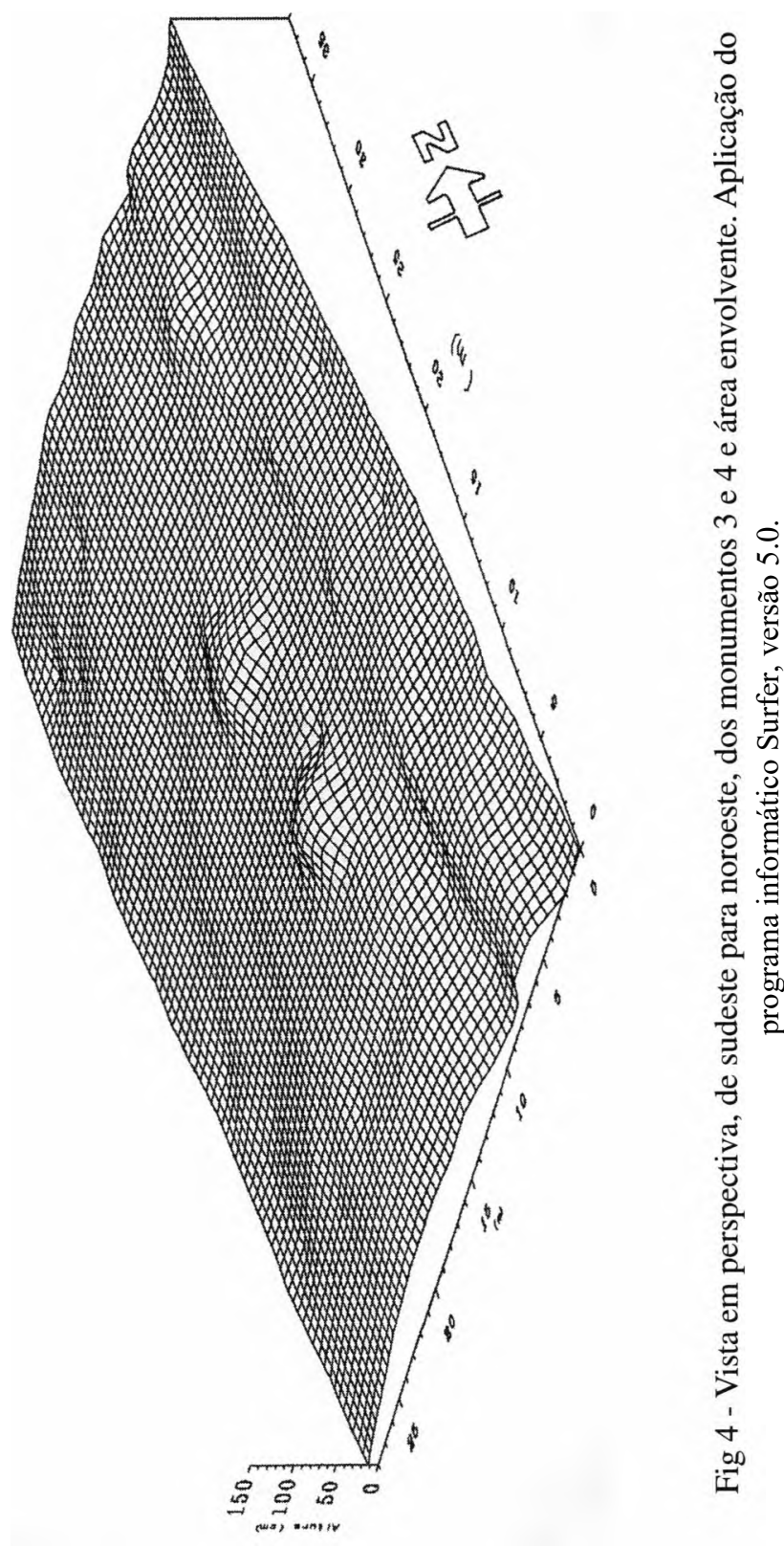


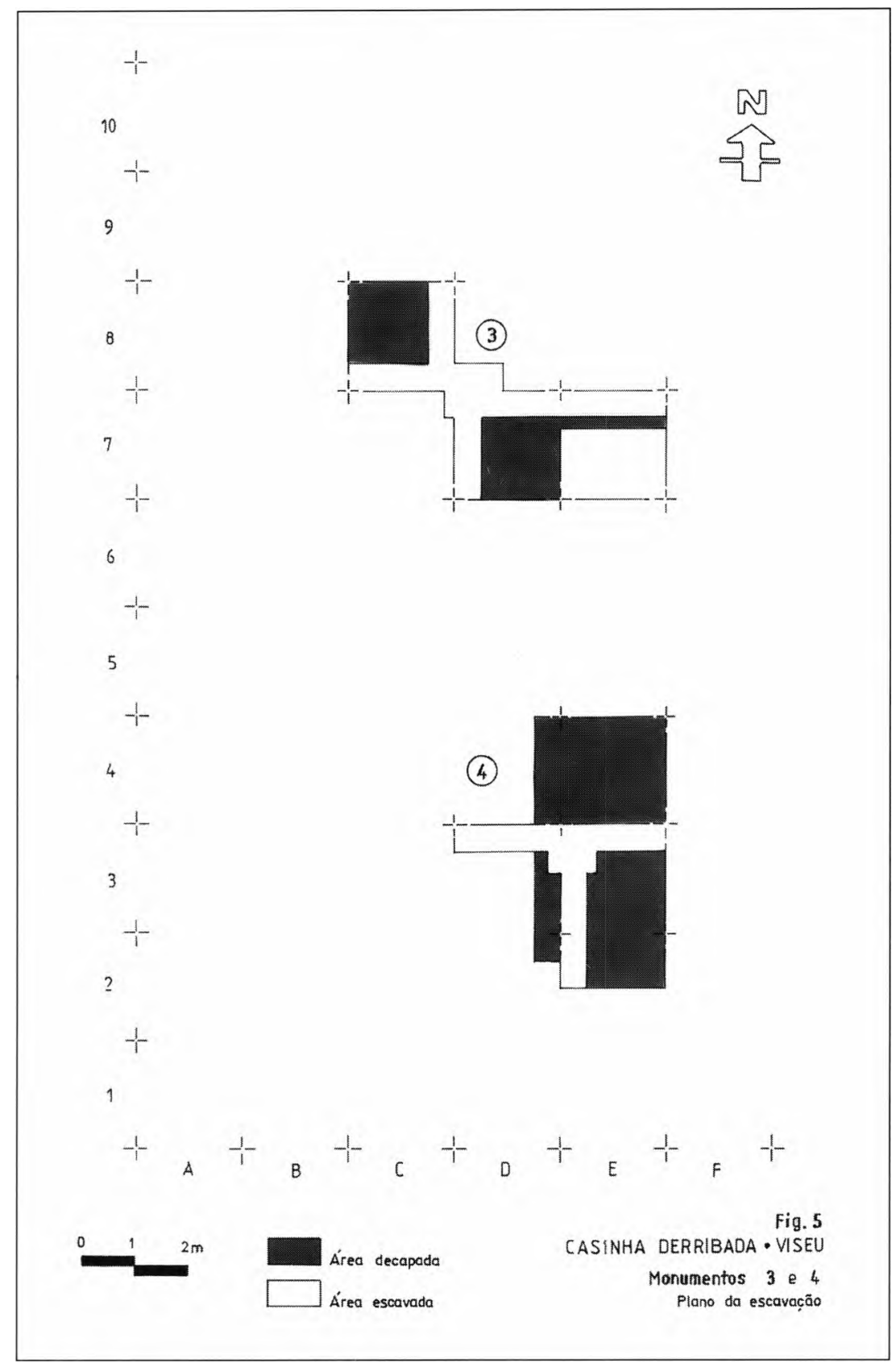


Fraga), tributárias do Pavia, que correm, em amplos vales, de nordeste para sudoeste; a norte, com a direcção SO-NE, correm outras, subsidiárias do Vouga (Lameirão e Piolho).

A cobertura vegetal traduz intensa actividade desde tempos remotos, visível na própria toponímia (Casal, Póvoa, etc.); as plantações de pinhal dominam a paisagem, para além das clareiras criadas pelos incêndios de tempo recente. $O$ povoamento é disperso; faz-se em "lugares", alguns já de grandes dimensões e "quintas", com Viseu a servir de polo aglutinador. Os recursos são predominantemente agrícolas; algumas explorações minerais, sobretudo de estanho e volfrâmio, têm hoje reduzida importância económica.

\section{Os monumentos 3 e 4}

\subsection{Metodologia da escavação}

Os monumentos 3 e 4 , alinhados aproximadamente no sentido norte-sul, distam um do outro, a partir dos seus pontos centrais, cerca de 8 metros. Face à proximidade, foi estabelecida uma quadriculagem geral, orientada segundo o norte magnético, correspondendo a um rectángulo com 20 metros no sentido N-S e 12 metros, no sentido E-O, subdividido em quadrados de 2 metros de lado (Fig. 5; Foto 1).

O levantamento topográfico da área assim definida, com leituras com aproximação ao centímetro e malha de 1 metro, foi executado com um teodolito de segundos, a partir de um ponto convencional, de cota zero, localizado no eixo do caminho atrás referido (Fig. 2, 3 e 4). Este ponto auxiliar de topografia será, futuramente, integrado no micro-levantamento da área, englobando os cinco monumentos que constituem o núcleo da "Casinha Derribada".

A massa tumular do monumento 3 distribui-se, fundamentalmente, pelos quadrados C7, C8 e D7, D8; o monumento 4 ocupa os quadrados D3, D4 e E3, E4 (Fig. 5).

A área quadriculada, e todo o sector a ocidente do caminho carreteiro, apresentava parca vegetação devido aos múltiplos incêndios que nestes últimos anos atingiram esta área do concelho de Viseu. Os terrenos situados a leste do referido caminho foram recentemente arroteados e plantados com pinhal. 


\subsection{Descrição dos trabalhos}

\subsubsection{Monumento 3}

Fez-se a decapagem superficial dos quadrantes $\mathrm{NO}$ e SE, realizando-se então o primeiro registo planimétrico, por desenho, à escala de 1: 20, para além dos registos fotográficos. Fez-se também a cotagem dos blocos mais significativos, utilizando-se o ponto auxiliar de topografia atrás referido (Fig. 6).

Desde estes primeiros trabalhos era evidente tratar-se de uma estrutura arqueológica, de planta circular, medindo cerca de 4 metros de diâmetro, assumindo a forma de tumulus em pedra, fundamentalmente constituído por pequenos blocos de quartzo, de cor esbranquiçada, a que se associavam, por vezes, algumas lajes de micaxisto; perifericamente definia-se um círculo de pedras, também de quartzo, mas mais volumosas, estabelecendo o limite exterior da estrutura. Por outro lado, observava-se a sua reduzida volumetria, pouco se salientando da superfície natural (Figs. 2 a 4, 7 e 8).

A área central do monumento apresentava-se desprovida de pedras, não correspondendo tal situação a uma violação profunda, como se veio a verificar posteriormente; também na área oeste se assinalava uma acumulação de pedras, algo circular (Fig. 6), mas cuja escavação permitiu verificar que não terá feito parte da estrutura original, embora se trate de uma deposição antiga, face à compactação evidenciada.

A estes registos e observações seguiram-se os trabalhos de escavação, por sondagem; para o efeito foram abertas quatro sanjas (norte, sul, oeste e este), com $0,50 \mathrm{~m}$ de largura, interceptando-se na parte central do monumento. A desmontagem da estrutura pétrea e o desenvolvimento da escavação permitiu a observação interna do tumulus e o seu estudo, com a realização de dois perfis longitudinais (N-S e

O-E), mas com leitura em dois sentidos (Figs. 7 e 8 ).

$\mathrm{Na}$ parte central do monumento foi, desde logo, identificada uma grande laje, de granito, medindo cerca de $0,70 \mathrm{~m}(\mathrm{~N}-\mathrm{S})$ e $0,65 \mathrm{~m}$ (O-E), com insculturas (Foto 2). Foi, assim, necessário alargar a escavação desta área, no sentido da definição das dimensões e extensão deste elemento. Recoberta por uma fina camada de terras castanho-amareladas, era perifericamente envolvida por terras do mesmo tipo, evidenciando elevado número de materiais lenhosos carbonizados. Muito superficialmente, detectou-se — apenas na área desprovida de

Conimbriga, 37 (1998), 5-76 
$\mathbb{N}$

s

70

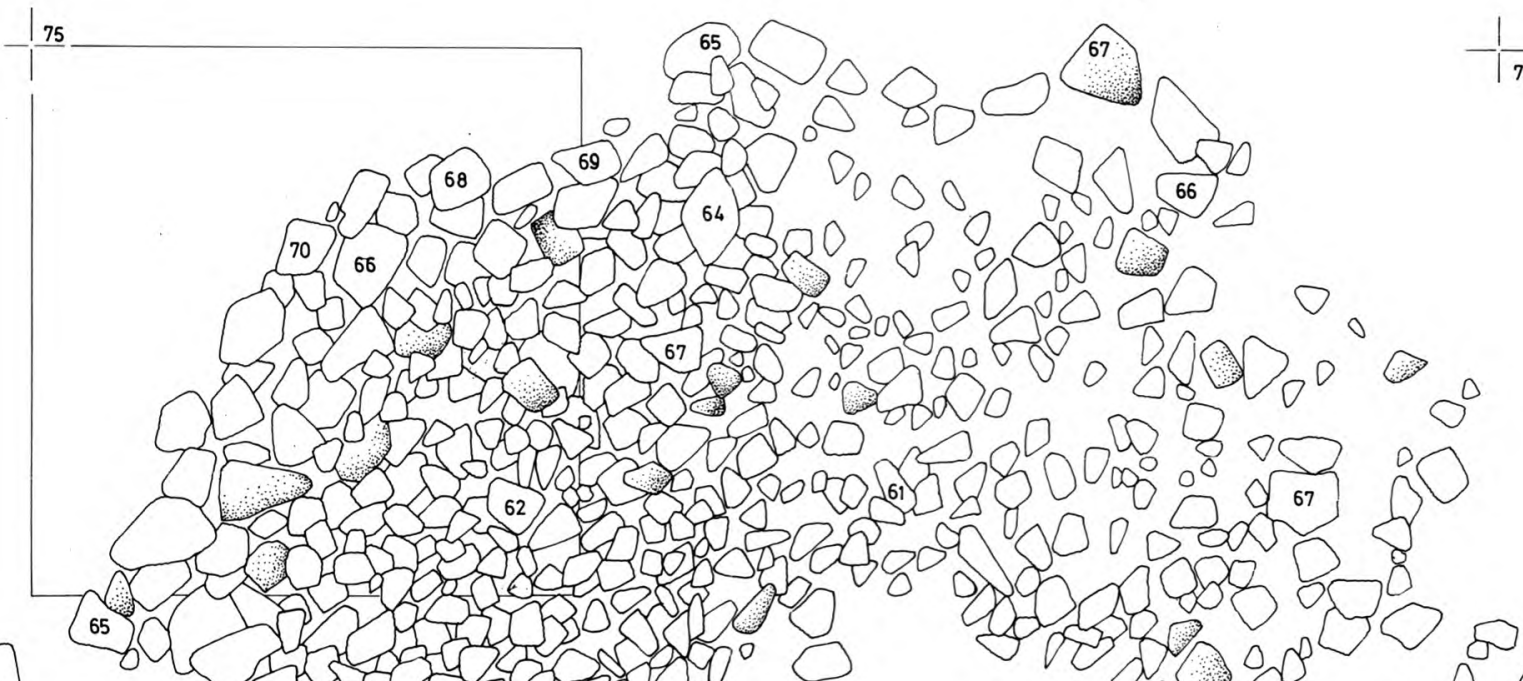

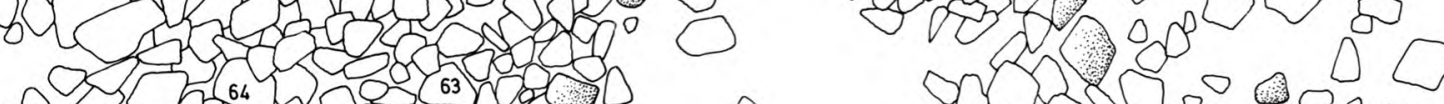
-180 or 61 ,

100507000000

GOSOL $2800 \%$

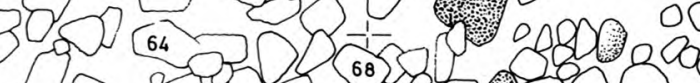
0 a

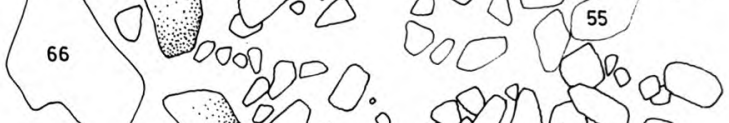

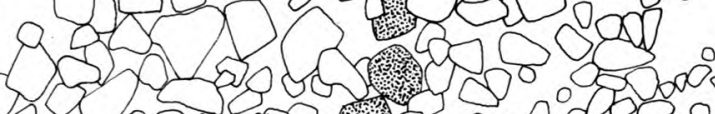

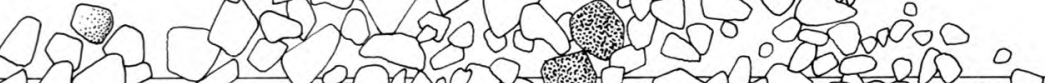

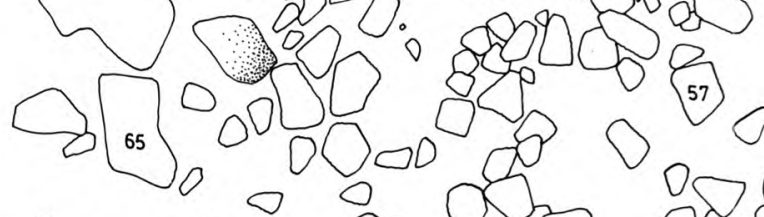

82 80 o

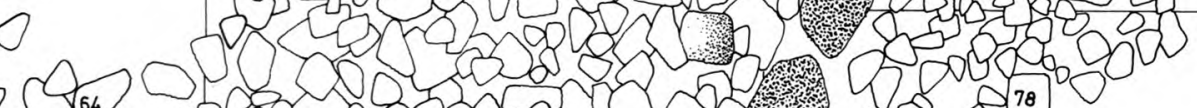
00800500000

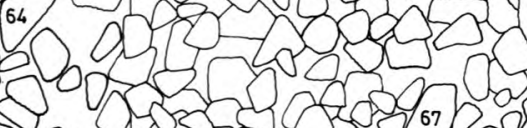
198008

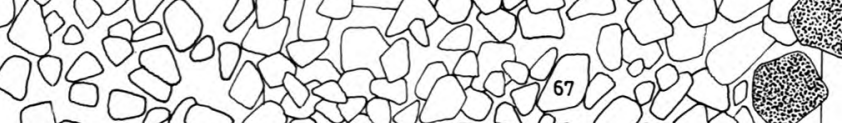

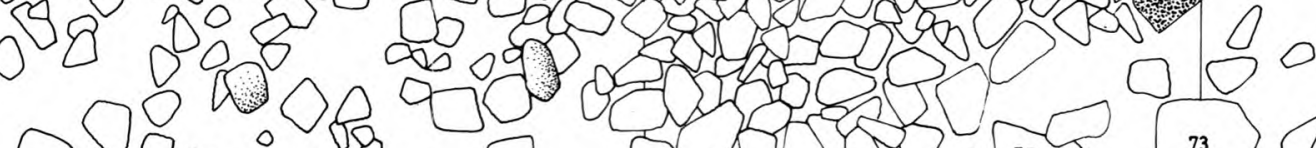

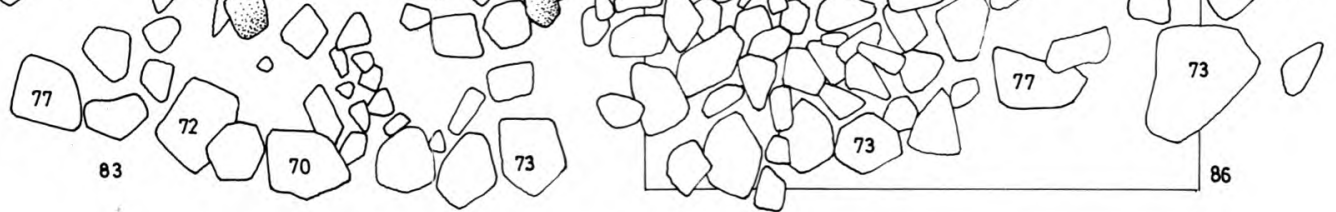

a 2073

\begin{tabular}{|c|c|c|}
\hline \multirow{3}{*}{ INSTITUTO } & \multicolumn{2}{|c|}{ Monumento 3 da CASINHA DERRIBADA - Viseu } \\
\hline & \multirow{2}{*}{ PLANTA } & \\
\hline & & Fig. 6 \\
\hline
\end{tabular}

ED Quartzo/Quartzito

(1) Micaxisto

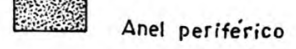

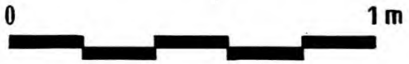

69 
(Página deixada propositadamente em branco) 
pedras -, uma fina pHí ula de terras negras, carbonosas, de formação recente.

Em suma, esta laje (que mais tarde se verificou tratar-se da tampa de uma fossa escavada no substrato argiloso) estava envolvida por um pequeno tumulus de terra, medindo cerca de 2 metros de diâmetro e entre $0,15 \mathrm{~m}$ a $0,20 \mathrm{~m}$ de altura, sobre o qual foi colocado um revestimento pétreo, bastante denso e embricado, à base de pequenos blocos de quartzo, perifericamente definido com blocos de maiores dimensões, perfazendo cerca de 4 metros de diâmetro.

A estratigrafía evidenciada não pode ser complexa, face à reduzida possança do corte: as terras do tumulus, castanho-amareladas, correspondem à camada 2, depositadas directamente sobre o soco natural (ou sobre as parcas terras originais do sítio — se é que existiam —, não tendo sido possível destrinçá-las daquelas, pela granulometria, cor, textura, etc.); a camada 1 diz também respeito às terras do tumulus existentes sob a estrutura pétrea de revestimento e sobre a laje de granito (desprovida de pedras), um pouco mais escuras, por serem mais superficiais e por isso terem sofrido pedogénese algo distinta, o mesmo sucedendo na periferia do conjunto tumular (camada la) (Figs. 7 e 8).

Foi então removida a laje de granito. Sob esta deparou-se-nos uma fossa, não totalmente preenchida com terra, evidenciando que, após a deposição do espólio, foi encerrada, permanecendo hermeticamente fechada, para o que terá contribuído o carácter plástico dos materiais constituintes do subsolo. A pouca terra existente no seu interior terá, assim, resultado do esboroamento das paredes da própria fossa, por força da infiltração das águas pluviais, justificando esta situação, também, a fractura de dois dos vasos exumados, pela pressão, associada às amplitudes térmicas, provocada por aquela.

A fossa é de planta sub-rectangular, medindo cerca de $0,60 \mathrm{~m}$ de comprimento $(\mathrm{N}-\mathrm{S}), 0,40 \mathrm{~m}$ de largura e $0,24 / 0,26 \mathrm{~m}$ de profundidade (Fig. 7; Foto 3); situada na parte central do conjunto tumular, foi escavada no substrato argiloso de base.

Do interior desta fossa foram exumados 4 vasos cerâmicos; dois deles apresentavam-se fracturados. O conteúdo de um dos vasos, que se encontrava em posição original, foi recolhido para análise $\left({ }^{13}\right)$.

Foi também recolhido um pequeno fragmento de carvão que, cuidamos, não terá significado especial — em termos de interpretação

(13) Em curso no Centro de Pedologia da Universidade Técnica de Lisboa.

Conimbriga, 37 (1998), 5-76 


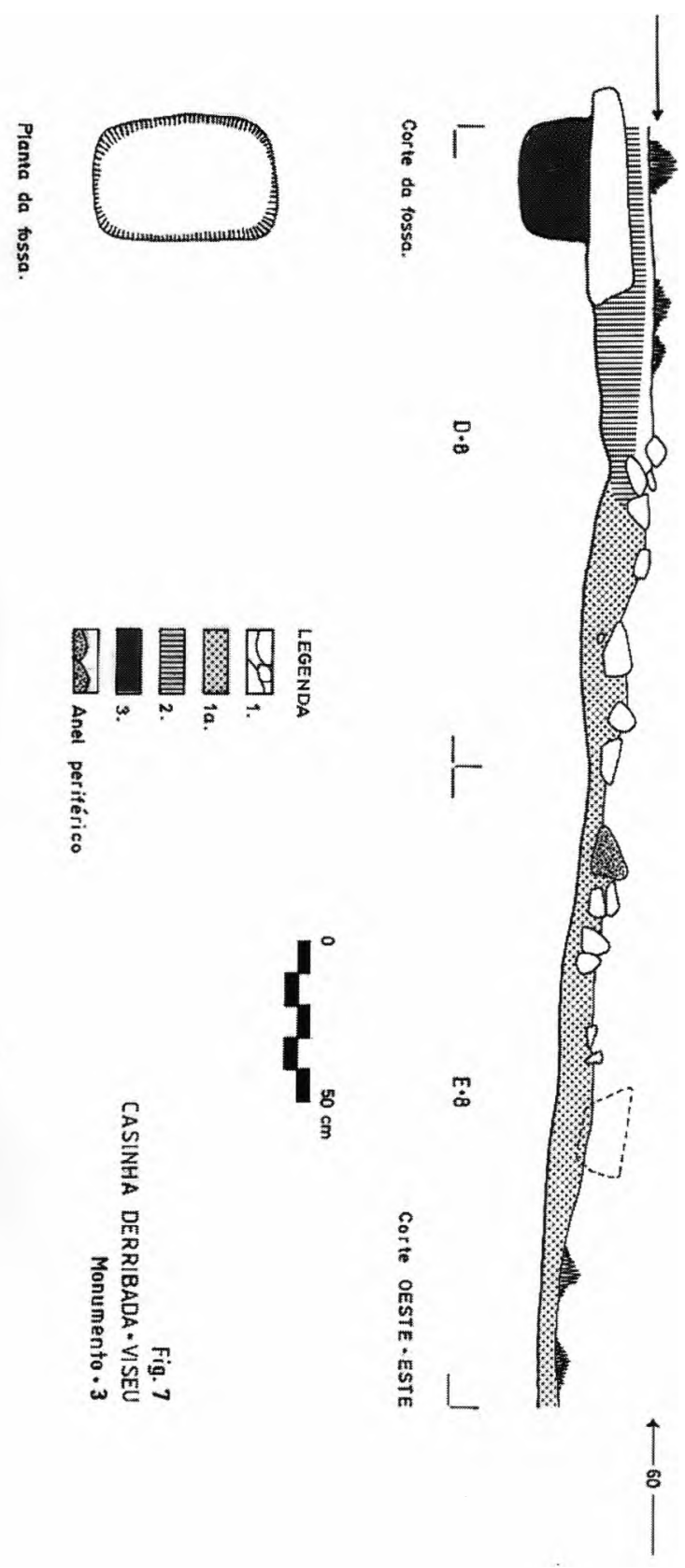




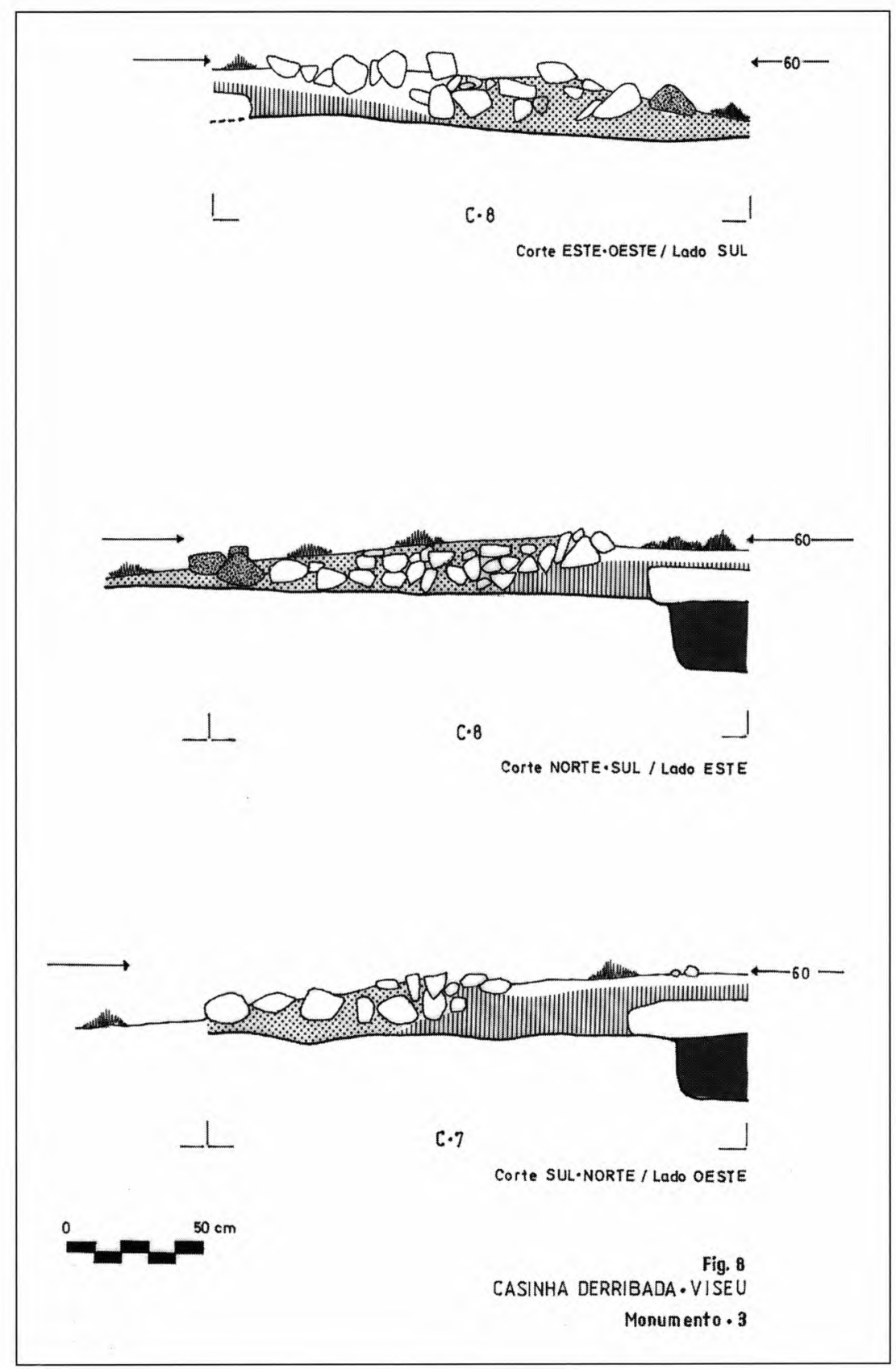


paleoetnológica -, tratando-se, certamente, de madeira carbonizada acidentalmente caída para o seu interior, com a abertura da fossa ou a deposição daqueles materiais.

\subsubsection{Monumento 4}

O monumento, após os trabalhos de limpeza superficial, mostrava externamente características muito semelhantes às do anterior.

Realizou-se uma primeira planta com o tumulus apenas limpo de vegetação (Fig. 9). Fez-se, então, a decapagem dos quadrantes NE e SE, e uma segunda planta, por desenho, à escala de 1: 20, e correspondente levantamento de cotas das pedras mais significativas (Fig. 9).

Foram abertas duas sanjas, com $0,50 \mathrm{~m}$ de largura: a primeira, longitudinal, no sentido oeste-este, passando pelo centro do monumento; a segunda, perpendicular àquela, no sentido sul-norte; a sua escavação permitiu a realização de dois perfis longitudinais (O-E e E-O).

A estratigrafía evidenciada é semelhante à observada no Monumento 3: as terras do tumulus, castanho-amareladas, muito finas e compactas, correspondem à camada 2, depositadas directamente sobre a superficie natural do sítio; a camada 1 diz também respeito às terras do tumulus existentes sob a estrutura pétrea de revestimento, um pouco mais escuras (Fig. 10).

$\mathrm{Na}$ parte central desta estrutura pétrea definiu-se o contorno de uma pequena fossa, preenchida com terras negras, carbonosas, contrastando, por isso, com as terras envolventes, constituintes do tumulus.

A fossa é de planta ovalada, medindo cerca de $0,45 \mathrm{~m}$ de eixo maior e $0,32 \mathrm{~m}$ de eixo menor; atingia o máximo de $0,15 \mathrm{~m}$ de profundidade; a abertura era acentuada por blocos de quartzo dispostos em círculo (Fig. 10).

Esta fossa, cujas dimensões são bastante reduzidas, foi também aberta no substrato; era recoberta por uma camada de terras, castanho-amareladas, que se estendia muito para além do seu perímetro; a sua espessura não ultrapassa os $0,10 \mathrm{~m}$; sobre estas terras desenvolvia-se então a estrutura pétrea de revestimento, adensando-se particularmente na sua área central (Fig. 9).

Conimbriga, 37 (1998), 5-76 


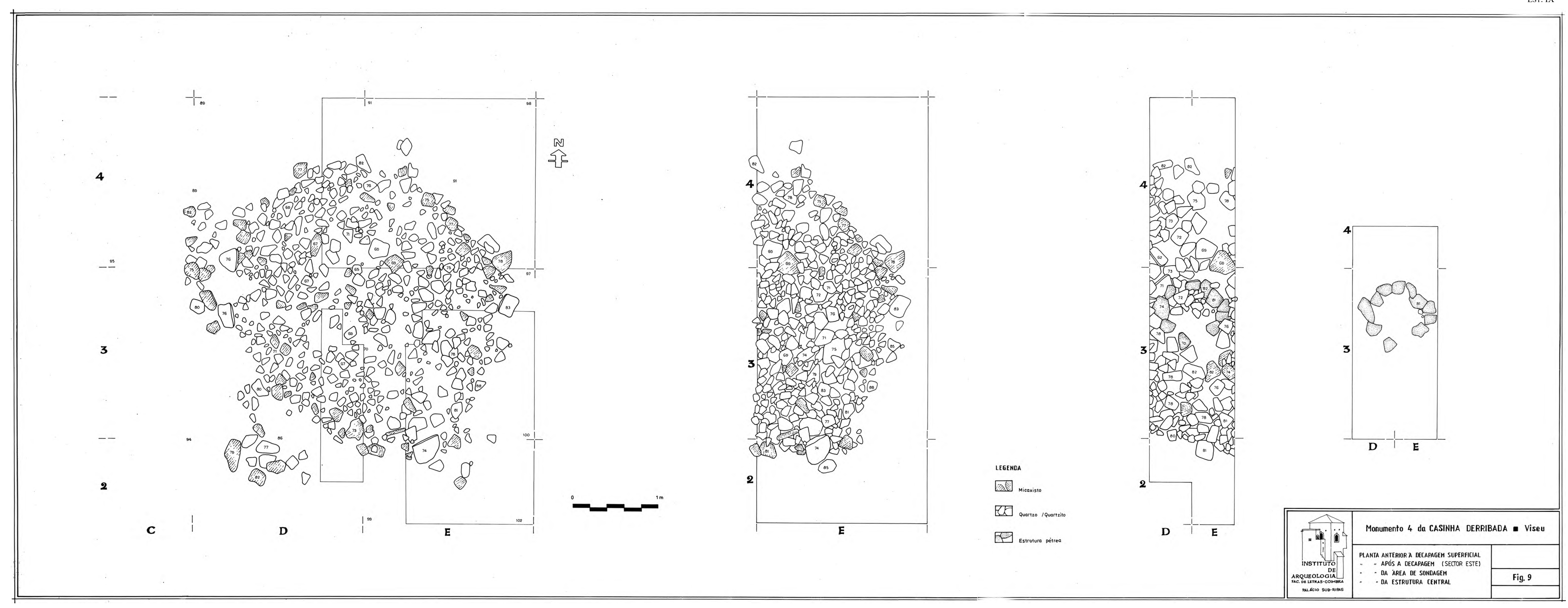


(Página deixada propositadamente em branco) 


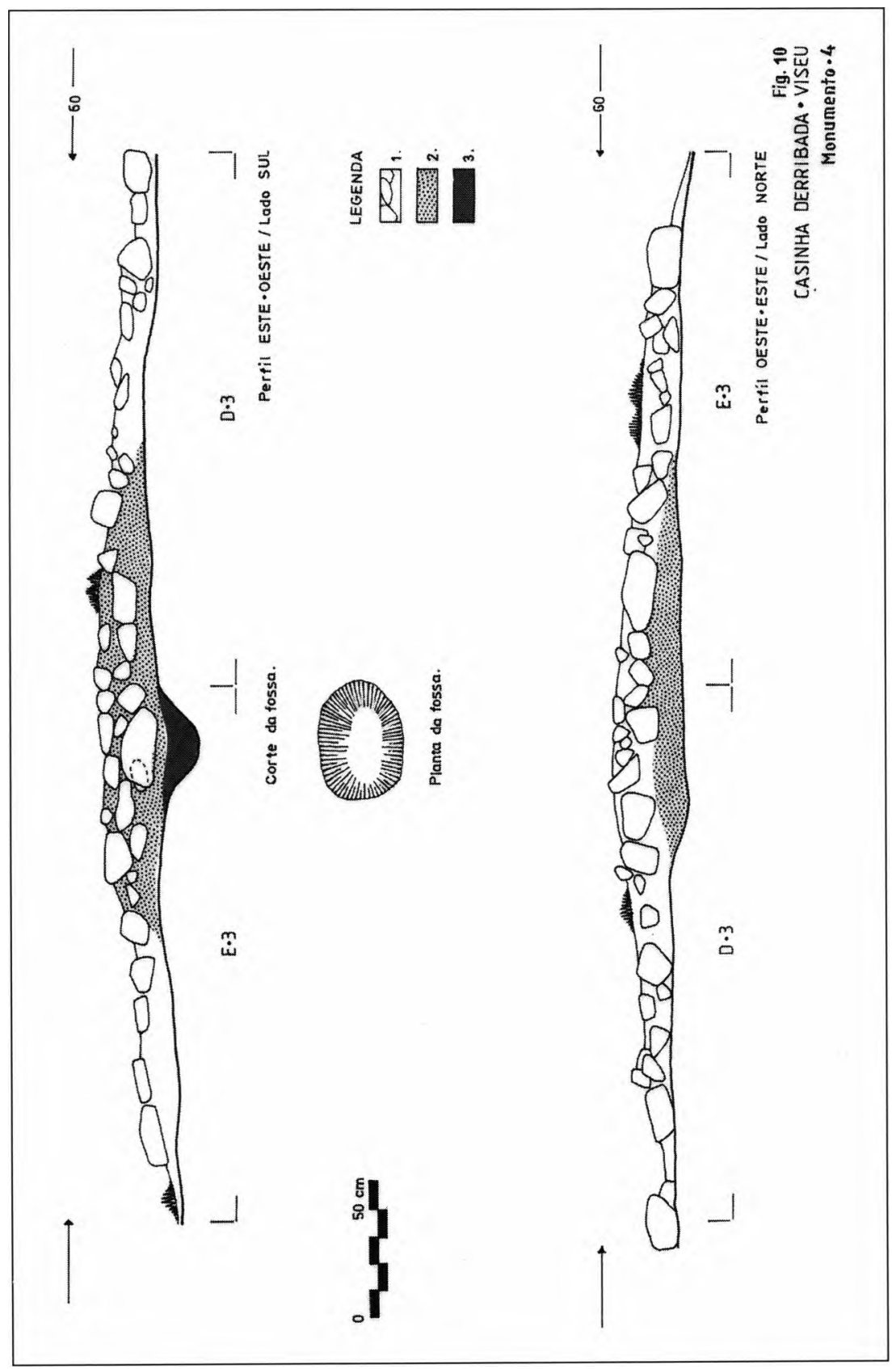




\subsection{Amostragens paleoambientais}

No Monumento 3 foram recolhidas amostras de terra para a realização de análises palinológicas; a amostragem foi realizada em coluna estratigráfica, em 12 de Julho de 1993, em dia seco, não ventoso.

n. ${ }^{\circ} 1$ - terras de cor castanho-amarelada, com numerosos elementos grosseiros, por vezes centimétricos; correspondem ao nível de transição entre o substrato e as terras do tumulus.

n. ${ }^{\circ} 2$ - terras castanho-amareladas, plásticas, com raízes finas e muito finas; terras do tumulus;

n. ${ }^{\circ} 3$ - terras castanho-amareladas, plásticas, com raízes finas e muito finas; topo das terras do tumulus;

n. ${ }^{\circ} 4$ - terras castanho-acinzentadas, pouco compactas, com raízes de calibres médio e fino; correspondem aos sedimentos existentes imediatamente sob e entre as pedras da estrutura pétrea de revestimento.

\begin{tabular}{|c|c|c|c|c|c|c|}
\hline \multirow[t]{2}{*}{$\mathrm{Am}$. } & \multirow[t]{2}{*}{ Quad. } & \multicolumn{4}{|c|}{ Coordenadas $(\mathrm{cm})$} & \multirow[t]{2}{*}{ Observações } \\
\hline & & $x$ & $\mathrm{y}$ & $\mathrm{z}$ & $z^{\prime}$ & \\
\hline 1 & D7 & 15 & 66 & 124 & 11 & \multirow{12}{*}{ Lab. C14 Groningen } \\
\hline 2 & D7 & 28 & 92 & 125 & 10 & \\
\hline 3 & D7 & 46 & 40 & 120 & 11 & \\
\hline 4 & D7 & 90 & 28 & 121 & 10 & \\
\hline 5 & D7 & 60 & 25 & 123 & 13 & \\
\hline 6 & D7 & 59 & 37 & 122 & 11 & \\
\hline 7 & D7 & 49 & 41 & 121 & 10 & \\
\hline 8 & D7 & 46 & 74 & 124 & 10 & \\
\hline 9 & D7 & 31 & 39 & 122 & 10 & \\
\hline 10 & D7 & 62 & 18 & 122 & 14 & \\
\hline 11 & D7 & 38 & 66 & 125 & 12 & \\
\hline 12 & D7 & 43 & 38 & 125 & 12 & \\
\hline 13 & $\mathrm{C} 8$ & 182 & 163 & 126 & 15 & Lab. C14 Groningen \\
\hline 14 & $\mathrm{C} 8$ & 162 & 180 & 126 & 16 & Lab. C14 Oxford \\
\hline 15 & $\mathrm{C} 8$ & 184 & 192 & 128 & 18 & Lab. C14 Oxford \\
\hline 16 & D7 & 14 & 8 & 96 & 33 & Lab. C14 Oxford \\
\hline
\end{tabular}

(14) As coordenadas, em cada quadrado com $2 \mathrm{~m}$ de lado e o observador orientado a norte, dizem respeito às seguintes medidas: $\mathrm{x}$ - distância medida no sentido oeste-este; y - idem, no sentido sul-norte; $\mathrm{z}$ - profundidade relativa medida a partir do ponto auxiliar de topografia de cota $0.0 ; z^{\prime}$ - profundidade real.

Conimbriga, 37 (1998), 5-76 
No âmbito dos estudos antracológicos (15) recolheram-se no Monumento 3, ao longo dos trabalhos de escavação, nas terras do tumulus, 15 amostras de madeira carbonizada, algumas das quais utilizadas em análises radiocarbónicas. Foram também processados, por flutuação, cerca de $15 \mathrm{Kg}$ de sedimentos, recolhidos no quadrado C8 (terras do tumulus, castanho-amareladas, que envolviam a laje de cobertura da fossa) (Quadro I).

\subsection{Espólio cerâmico}

O monumento 3 forneceu, como se disse, quatro recipientes cerâmicos: duas taças e dois vasos de colo alto e abertura estreita (Figs. 11 e 12; Fotos 4 a 6). Apenas o vaso n. ${ }^{\circ} 1$ estava em posição vertical, não completamente preenchido de sedimentos, como, aliás, a própria fossa. Uma das taças, completa, estava adossada a este vaso, mas em posição lateral, ocupando a "cabeceira" norte da fossa. Os outros dois recipientes ocupavam a parte central e sul deste espaço; o vaso (n. ${ }^{\circ}$ 2) estava fragmentado, mas completo, tendo a seu lado a segunda taça, também fragmentada.

Trata-se de dois grupos de vasos, similares, cujo volume preencheria quase totalmente o espaço útil da fossa. Encontrar-se-ão próximo das posições originais, ainda que seja de admitir pequenas deslocações provocadas pela água que, de quando em quando, terá preenchido a cavidade, situação observável na superfície das vasilhas com a inscrustação de sais solúveis; a fragmentação de dois dos recipientes ter-se-á ficado a dever, como já se referiu, à pressão provocada pelo enchimento da fossa com água e às amplitudes térmicas.

1 - vaso completo, de pança ovoide e colo alto, troncoconico, suavemente ligado ao corpo (perfil em S); bordo de extremidade arredondada, levemente esboroado; fundo plano-convexo, espessado na parte central; asa de fita, de secção subelíptica, aplicada a partir do bordo até ao arranque do colo; pasta compacta com elementos não plásticos de calibre médio, por vezes grosseiro, à base de areias quartzosas; superfícies polidas, por vezes erodidas,

(15) A análise dos materiais lenhosos macroscópicos foi realizada pela Doutora Isabel Figueiral, investigadora do Instituto Botânico da Universidade de Montpellier (França), colaboração que agradecemos. Vide relatório publicado neste volume.

Conimbriga, 37 (1998), 5-76 


$$
\begin{aligned}
& 10 \\
& 0
\end{aligned}
$$




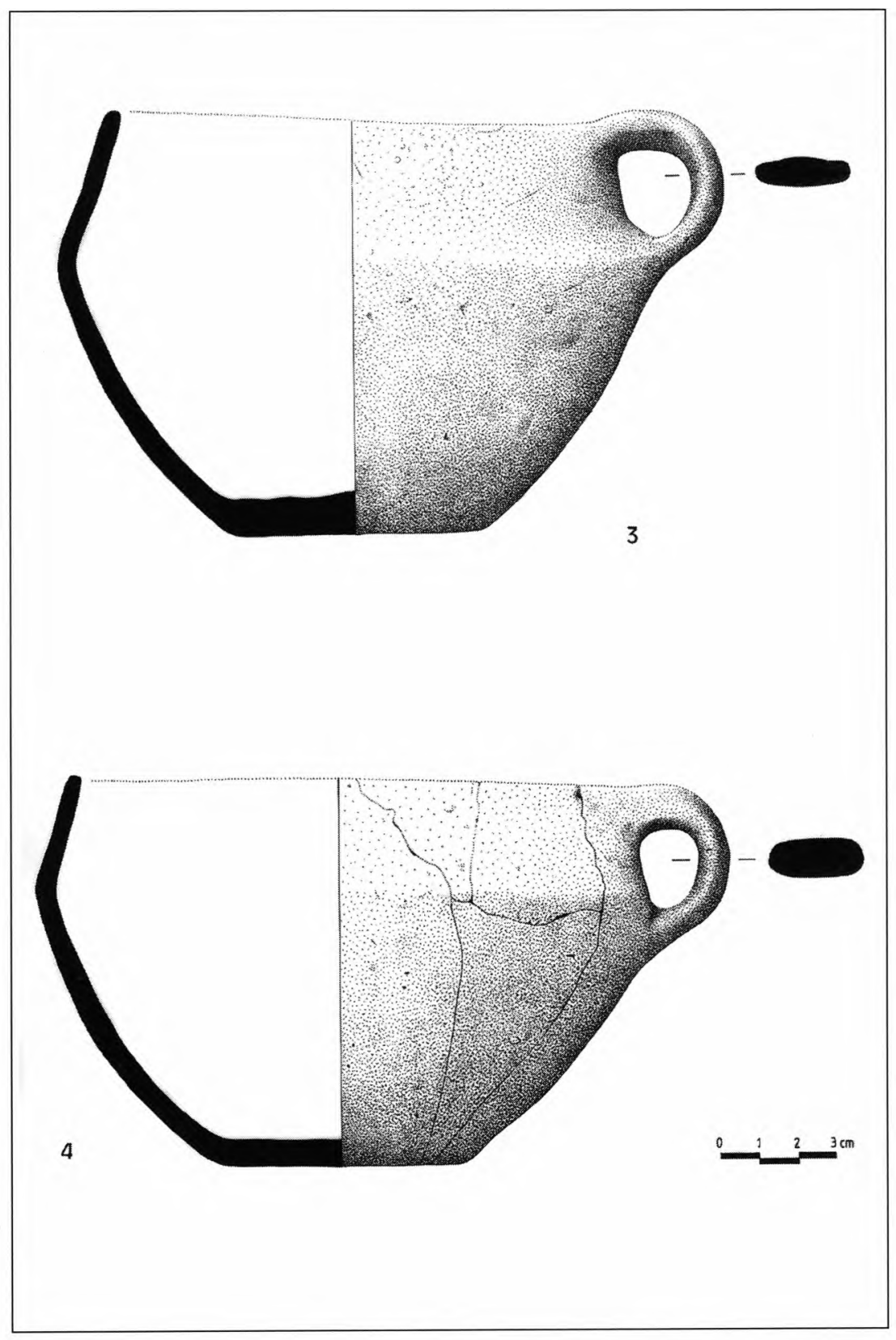

Fig. 12 - Espolio cerâmico. 
de cor castanho-acinzentada, com manchas de negro de fumo; medidas: alt. 15,2 cm; diâm. máx. - 16,3 cm; diâm. da boca $-8 \mathrm{~cm}$; diâm. da base $-6,5$ cm; esp. - 0,7-0,9 mm (Fig. 11-1);

2 - vaso completo, de pança ovoide e colo alto, troncoconico, muito inclinado, fechado; ligação do corpo ao colo marcada; bordo de extremidade arredondada; fundo plano-convexo; asa de fita (em bobina), de secção subelíptica, aplicada a partir do bordo até à linha de separação da pança/colo; decoração: 6 mamilos sobre a linha de separação pança/colo; pasta compacta com elementos não plásticos de calibres médio e grosseiro, à base de areias quartzosas; superfícies polidas, por vezes erodidas (a externa e a base), de cor castanho-acinzentada, com manchas de negro de fumo; medidas: alt. $-16,1$ cm; diâm. máx. - 16,6 cm; diâm. da boca - 7,6 cm; diâm. da base - 8,5 cm; esp. - 0,45-0,7 mm (Fig. 11-2);

3 - taça completa, de carena média/alta, fechada; bordo inclinado para o interior, de extremidade arredondada; corpo hemisférico; fundo plano, espessado na parte central, com lascamento; asa de fita, de secção sub-rectangular, aplicada a partir do lábio até à carena; pasta compacta, com elementos não plásticos de calibre médio, por vezes grosseiro; superfície externa polida, por vezes brilhante, de cor castanho-avermelhado, com manchas de negro de fumo; medidas: alt. — 10,3 cm; diâm. máx. — 16,9 cm; diâm. da boca - $12 \mathrm{~cm}$; diâm. da base — 6,4 cm; esp. — 0,4-0,55 mm (paredes) e 10,5 mm (base) (Fig. 12-1);

4 - taça completa, de carena alta, fechada; bordo inclinado para o interior, de extremidade arredondada; corpo hemisférico, com pequeno lascamento; fundo plano, com lascamento; asa de fita, de secção subelíptica, aplicada a partir do lábio; pasta compacta, com elementos não plásticos de calibre médio, por vezes grosseiro; superfície extema polida, por vezes brilhante, de cor castanho-avermelhado, com manchas de negro de fumo; medidas: alt. — 9,7 cm; diâm. máx. — 17,7 cm; diâm. da boca — 14 cm; diâm. da base — 6,3 cm; esp. — 0,4-0,55 mm (paredes) e 0,65 mm (base) (Fig. 12-2).

\subsection{Laje com gravuras}

O encerramento da fossa do monumento 3 foi feito, como se disse, com grande laje de granito, subquadrangular, medindo $0,70 \mathrm{~m} \mathrm{x}$ $0,65 \mathrm{~m}$, com a espessura de 0,16/0,08 m. A face exterior foi parcialmente regularizada para aplicação de um reticulado, formado por cinco sulcos no sentido do eixo maior (N-S), interceptados por quatro outros, no 
sentido oposto, formando espaços aproximadamente quadrangulares; os sulcos, largos, pouco profundos e irregulares, foram obtidos por picotagem (Foto 2). A face interna e os lados da laje não apresentam quaisquer gravuras.

\subsection{Datações radiocarbónicas}

Foram realizadas 5 análises radiocarbónicas (Quadro II); utilizaram-se amostras de madeira carbonizada recolhidas nas terras que constituíam o tumulus (Quadro I). Do interior do covacho foi também extraído um pequeno carvão vegetal (am. 16); embora não se tivesse valorizado excessivamente esta ocorrência, pois tratava-se do único vestígio de material orgânico identificável colhido neste espaço, procedeu-se à sua análise, pois admitia-se que pudesse relacionar-se com a cobertura vegetal existente no sítio à época da construção da estrutura, fosse com a destruição da vegetação pelos construtores para a implantação do tumulus, ou carvão residual pré-existente, fornecendo de qualquer modo um terminus ante quem para a construção; a fraca possança dos solos à data da abertura da fossa apontaria, em princípio, para a possibilidade de o referido carvão se relacionar com um momento próximo de tal acto.

O resultado da análise deste pequeno carvão é bastante recuado (OxA-4911: 8080190 BP), situável no VIII milénio cal. AC, certamente relacionável com um carvão vestigial existente nas terras do sítio, integrado na fossa por força da sua abertura e o revolvimento daquelas.

A análise GrN-20790:1840 \pm 100 BP foi realizada com carvão vegetal recolhido sobre a laje de cobertura; embora estratigraficamente não fosse observável qualquer anomalia de vulto (as terras que cobriam a laje eram similares às que se dispunham à sua volta, ainda que estas estivessem protegidas por um espesso revestimento de pedras), admitiu-se que pudesse de facto fornecer um resultado relacionável com o acto ritual que levou ao acender de uma fogueira sobre a referida laje (a abundância de carvões identificados sobre e em torno desta apontava nesse sentido); mas de facto, era temerário, pois sobre estes carvões estendia-se uma fina camada de terra, ainda que uniforme, com pouco mais de $10 \mathrm{~cm}$ de espessura, sendo de admitir a ocorrência de incêndios naturais, bem como a infiltração de elementos carbonosos mais recentes sem que tal fosse observável na estratigrafía. O resultado aponta para

Conimbriga, 37 (1998), 5-76 


\section{Quadro II - Datações radiocarbónicas do Monumento 3 da Casinha Derribada}

\begin{tabular}{|c|c|c|c|c|c|c|c|c|c|c|}
\hline \multirow[t]{3}{*}{ Ref. Lab. } & \multirow{3}{*}{$\begin{array}{l}\text { Datação } \\
\text { BP }\end{array}$} & \multicolumn{7}{|c|}{$\begin{array}{l}\text { Calibralo (AC) } \\
\text { (Stuiver e Pearson, 1993; Pearson e Stuiver, 1993; Pearson et al. 1993; } \\
\text { Linick et al., 1986) }\end{array}$} & \multirow[t]{3}{*}{$\begin{array}{c}\text { Tipo } \\
\text { de amostra }\end{array}$} & \multirow[t]{3}{*}{ Obs. } \\
\hline & & \multirow{2}{*}{ Inter- } & \multicolumn{2}{|c|}{ Método $\mathrm{A}$} & \multicolumn{4}{|c|}{ Método B } & & \\
\hline & & & 1 sigma & 2 sigma & 1 sigma & $\%$ & 2 sigma & $\%$ & & \\
\hline GrN*20790 & $1840 \pm 100$ & $215 A D$ & $\begin{array}{r}75-264 A D \\
281-329 A D \\
\end{array}$ & $36 \mathrm{AC}-420 \mathrm{AD}$ & $\begin{array}{l}77-263 \mathrm{AD} \\
283-327 \mathrm{AD} \\
\end{array}$ & $\begin{array}{l}84 \\
16 \\
\end{array}$ & $\begin{array}{l}32-16 \text { AC } \\
9-416 \text { AD }\end{array}$ & $\begin{array}{r}1 \\
99 \\
\end{array}$ & carvão vegetai & $\begin{array}{l}\text { am. } 5 \\
\text { sobre a laje de cobertura }\end{array}$ \\
\hline GrN-21303 & 31201110 & 1401 & $\begin{array}{l}1511-1259 \\
1233-1227 \\
\end{array}$ & $1620-1044$ & $\begin{array}{l}1513-1257 \\
1236-1222 \\
\end{array}$ & $\begin{array}{r}96 \\
4 \\
\end{array}$ & $1617-1048$ & 100 & carvão vegetai & $\begin{array}{l}\text { am. 13; terras do "tumulus", } \\
\text { sob revestimento pétreo }\end{array}$ \\
\hline Ox-A-5291 & 2985160 & $\begin{array}{l}1252 \\
1246 \\
1209\end{array}$ & $\begin{array}{l}1302-1274 \\
1269-1117\end{array}$ & $1395-1006$ & $1308-1115$ & 100 & $\begin{array}{l}1387-1336 \\
1325-1021\end{array}$ & $\begin{array}{l}8 \\
92\end{array}$ & carvão vegetai & $\begin{array}{l}\text { am. 14; terras do "tumulus", } \\
\text { sob revestimento pétreo }\end{array}$ \\
\hline OxA-4910 & 3115165 & 1398 & $\begin{array}{l}1430-1304 \\
1271-1270 \\
\end{array}$ & $\begin{array}{l}1515-1252 \\
1247-1207 \\
\end{array}$ & $\begin{array}{l}1435-1296 \\
1282-1268 \\
\end{array}$ & $\begin{array}{r}93 \\
7 \\
\end{array}$ & $\begin{array}{r}1516-1202 \\
1172-1169 \\
\end{array}$ & $\begin{array}{c}100 \\
0 \\
\end{array}$ & carvão vegetai & $\begin{array}{l}\text { am. } 15 \text {; terras do "tumulus". } \\
\text { sob revestimento pétreo }\end{array}$ \\
\hline OxA-4911 & 8080190 & 7035 & $\begin{array}{l}7232-7229 \\
9196-7184 \\
7138-7123 \\
7090-6997 \\
6918-6898 \\
6839-6786 \\
\end{array}$ & $7298-6648$ & $\begin{array}{l}7245-7219 \\
7203-7177 \\
7144-7117 \\
7099-6993 \\
6962-6863 \\
6845-6772 \\
\end{array}$ & $\begin{array}{l}6 \\
7 \\
7 \\
35 \\
24 \\
20 \\
\end{array}$ & $\begin{array}{l}7296-6691 \\
6687-6654\end{array}$ & $\begin{array}{c}98 \\
2\end{array}$ & carvão vegetai & am. 16; Interior da fossa \\
\hline $\begin{array}{l}\text { média pond. } \\
\text { (GrN-21303 } \\
\text { OxA-5291 } \\
\text { OxA-4910) }\end{array}$ & 3056142 & 1311 & $\begin{array}{l}1391-1332 \\
1329-1260 \\
1231-1229\end{array}$ & $\begin{array}{r}1411-1194 \\
1183-1164 \\
1141-1138\end{array}$ & $\begin{array}{l}1388-1336 \\
1326-1262\end{array}$ & $\begin{array}{l}44 \\
56\end{array}$ & $\begin{array}{l}1410-1197 \\
1180-1165 \\
1140-1139\end{array}$ & \begin{tabular}{l|}
98 \\
2 \\
0
\end{tabular} & $\begin{array}{l}\text { Teste estatístic } \\
\text { Xi2 (.05) - } 5.99\end{array}$ & $0 \mathrm{~T}^{\prime}-2.47$ \\
\hline
\end{tabular}

um momento situável nos primeiros séculos da nossa era, não se relacionando, seguramente, com a construção em estudo.

As restantes análises preferenciaram carvões vegetais identificáveis com o mesmo contexto (fogueira realizada sobre a laje de 


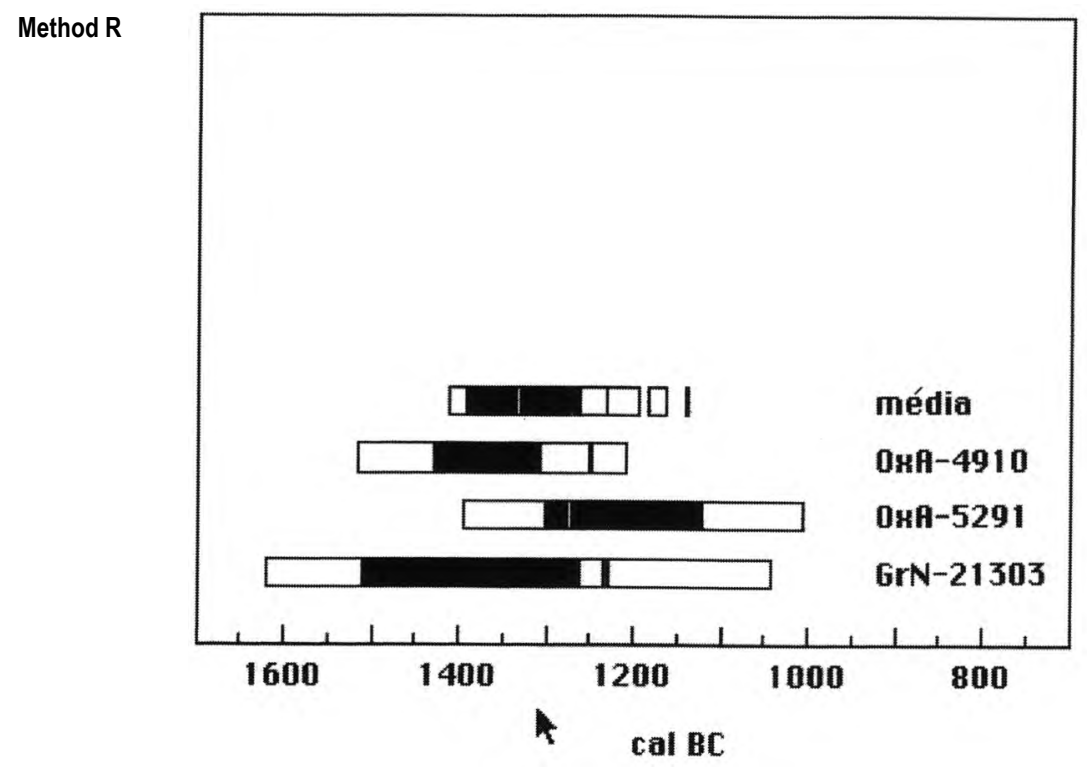

Fig. 13 - Representação gráfica das datações radiocarbónicas calibradas do monumento 3 da "Casinha Derribada". Período convencional "Libby" de 5568 anos e intervalos de confiança de \pm 1 sigma $(68,26 \%)$ e \pm 2 sigma $(95,46 \%)$. "Radiocarbon Calibration Program, rev. 3.0.3c", Quaternary Isotope Laboratory, University of Washington, com curva de 20 anos (seg. Stuiver e Reimer, 1993). Método A. Vide Quadro II. 
cobertura da fossa), mas oferecendo melhores condições de conservação em termos de estratigrafía, ou seja, existentes nas terras castanho-amareladas que cobriam a laje, formando um pequeno tumulus em seu tomo, mas sob a estrutura de pedras que foi depositada sobre aquelas.

$$
\text { Os resultados das análises GrN-21303 (3120 } \pm 110 \quad \text { BP), }
$$

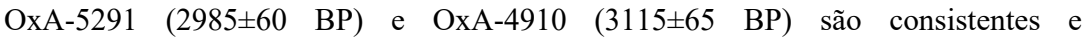
estatisticamente semelhantes (Quadro II, Fig. 13). GrN-21303, com um desvio-padrão mais elevado, apontará para um período aproximado de finais do século XVII e meados do século XI cal. AC; para o intervalo de confiança de 1 sigma, a probabilidade estatística de que a referida fogueira tenha sido realizada entre finais do século XVI e meados do século XIII cal. AC é bastante elevada (96\%).

OxA-5291 e OxA-4910 apresentam desvios-padrão mais reduzidos; a primeira, para o intervalo de confiança de 2 sigma, permite definir um período de inícios do século XIV e finais do século XI cal. $\mathrm{AC}$; a segunda, para a mesmo intervalo, compreende o período de finais do século XVI e finais do século XIII cal. AC.

Estas três análises apontam para um período máximo situável entre os finais do século XVII e os finais do século XI cal. AC. (Fig. 13).

Trata-se de resultados semelhantes, obtidos com amostras diferentes mas dizendo respeito, em princípio, ao mesmo contexto arqueológico; as análises foram, por outro lado, realizadas em laboratórios diferentes. Será, cremos, aceitável a sua ponderação.

$\mathrm{Se}$ valorizarmos as datações com menores desvios-padrão e, particularmente, a média ponderada destes três resultados, é admissível que o que se pretende datar se situe entre finais do século XV e meados do século XII a.C. ${ }^{16}$ ), cronologia que, numa primeira abordagem da questão, é aceitável para definir o momento de construção e actos rituais que ocorreram no monumento 3 da "Casinha Derribada", extensível, certamente, aos monumentos 4 e 5 , que lhe estão próximos, estruturalmente similares, ainda que sejam diversas as estruturas existentes no seu interior.

Sem dúvida que será possível aferir estes parâmetros com novas datações de amostras deste monumento e, sobretudo, com os resultados das análises que venham a ser realizadas com amostras do Monumento 2.

(16) Vide nota 2.

Conimbriga, 37 (1998), 5-76 


\section{Monumento 5}

\subsection{Metodologia da escavação}

Numa primeira fase, após os registos fotográficos iniciais, procedeu-se ao corte da vegetação rasteira, numa área de 144 metros quadrados, correspondendo a um quadrado de 12 metros de lado, orientado, tal como nos monumentos anteriores, segundo o norte magnético. A implantação deste tumulus fez-se em terreno não acidentado mas em plano levemente inclinado para $\mathrm{SO}$, correspondendo ao início da encosta sobranceira à povoação de Póvoa de Mundão (Figs. 15 a 17; Foto 7).

Após as limpezas superficiais dividiu-se o espaço atrás referido em quadrados de $2 \mathrm{~m}$ de lado. A cada um dos quadrados, no eixo O-E, foram atribuídas letras, de $\mathrm{A}$ a F; no eixo $\mathrm{S}-\mathrm{N}$, números de 1 a 6 (Fig.

14).

Procedeu-se ainda ao levantamento topográfico de uma área adjacente à quadriculagem com, para cada um dos lados, $28 \mathrm{~m}$ no eixo

O-E e $24 \mathrm{~m}$, no eixo N-S; o ponto de cota 0.00 convencional reporta-se ao topo de um afloramento rochoso - micaxisto - existente a aproximadamente $11 \mathrm{~m}$, para $\mathrm{NE}$, da área central do monumento. As leituras resultantes, com aproximação ao centímetro, são todas negativas (Fig. 15 a 17).

\subsection{Descrição dos trabalhos}

O Monumento 5 apresentava-se, à data do início dos trabalhos, como um pequeno montículo, constituído quase na sua totalidade por elementos pétreos de pequenas e médias dimensões, parcialmente "disfarçado" no meio da vegetação arbustiva que o cobria. Aparentemente, e com excepção de uma ligeira depressão na sua área central, não mostrava sinais evidentes de remeximentos profundos, nem vestígios do tipo de estrutura que, eventualmente, poderia encerrar.

Fez-se a decapagem da reduzida camada de terra humosa superficial que o cobria, nos quadrantes SE e NO, verificando-se então que se tratava de um pequeno tumulus, em pedra, de planta circular, medindo cerca de 5,10 metros de diâmetro, fundamentalmente constituído por pequenos e médios blocos de quartzo e quartzito, de cor

Conimbriga, 37 (1998), 5-76 


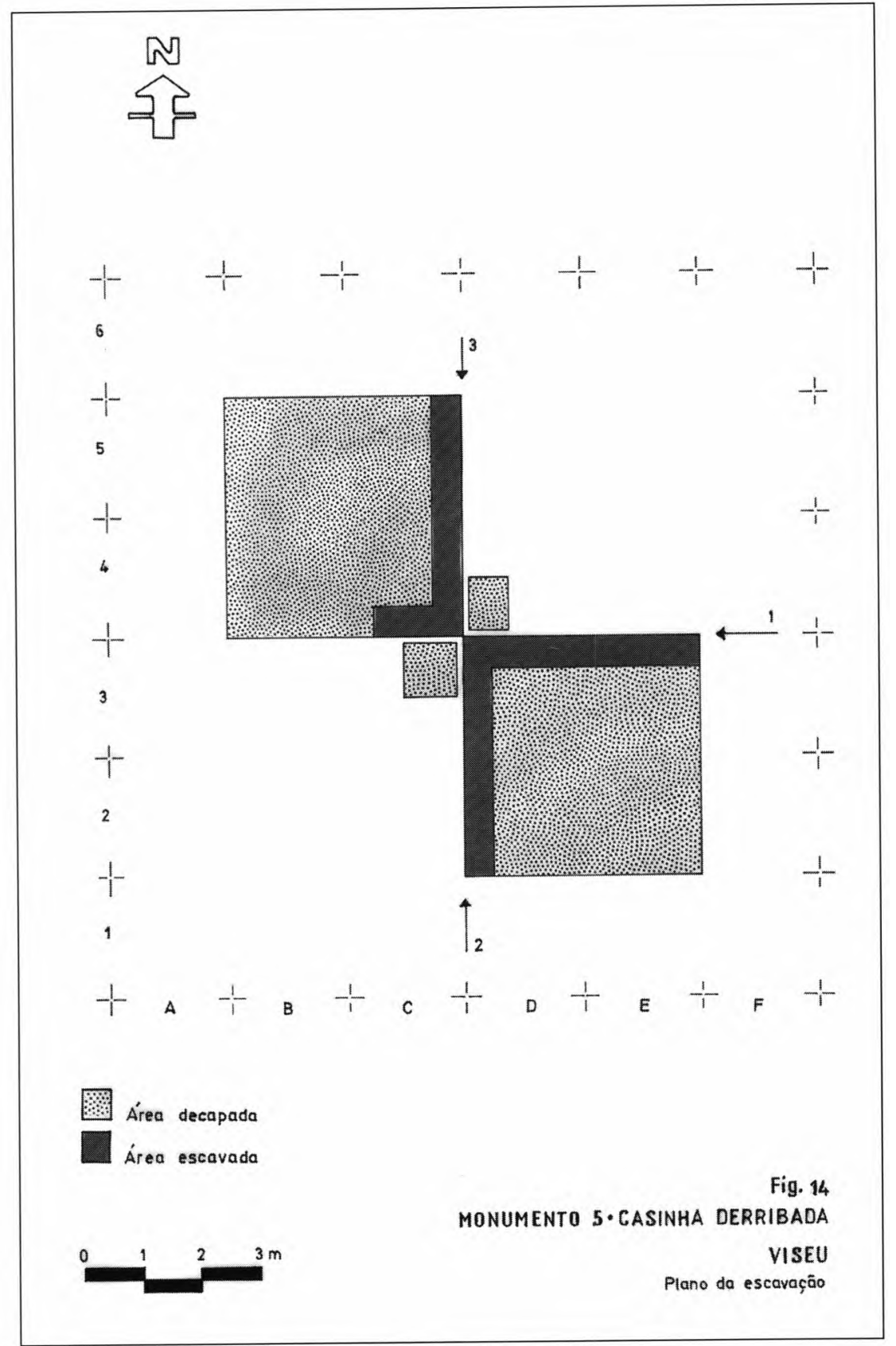




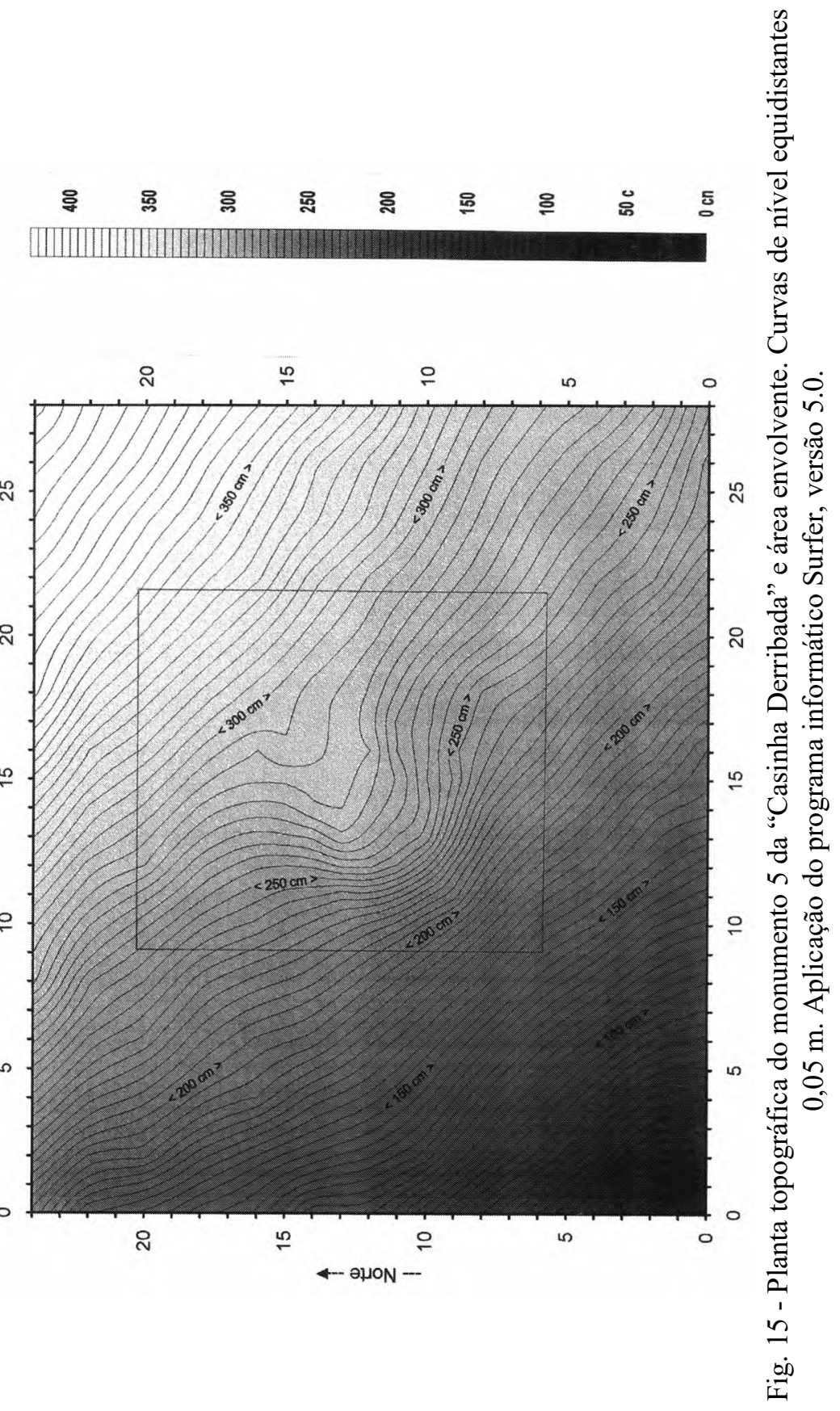




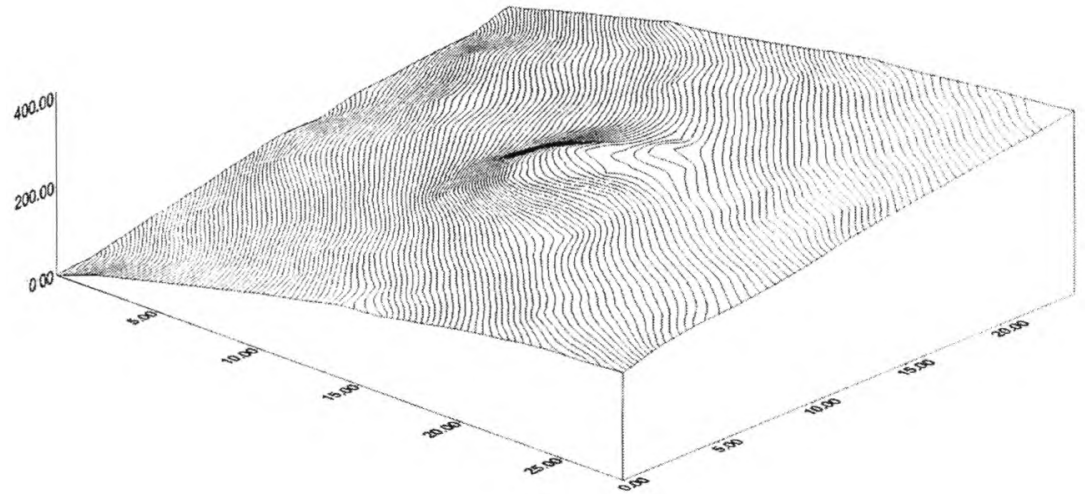

Fig. 16 - Monumento 5 da "Casinha Derribada". Visualização perspectiva, de SE-NO, com curvas de nível equidistantes $0,05 \mathrm{~m}$. Aplicação do programa informático Surfer, versão 5.0.

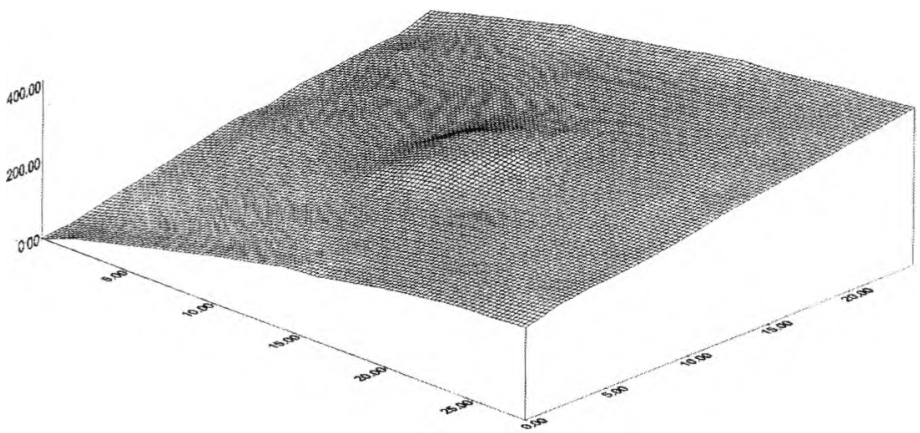

Fig. 17 - Monumento 5 da "Casinha Derribada". Visualização perspectiva, com linhas de intersecção das coordenadas geográficas com a superfície do terreno ("wire frame"), de SE-NO, com curvas de nível equidistantes 0,05 m. Aplicação do programa informático Surfer, versão 5.0. 


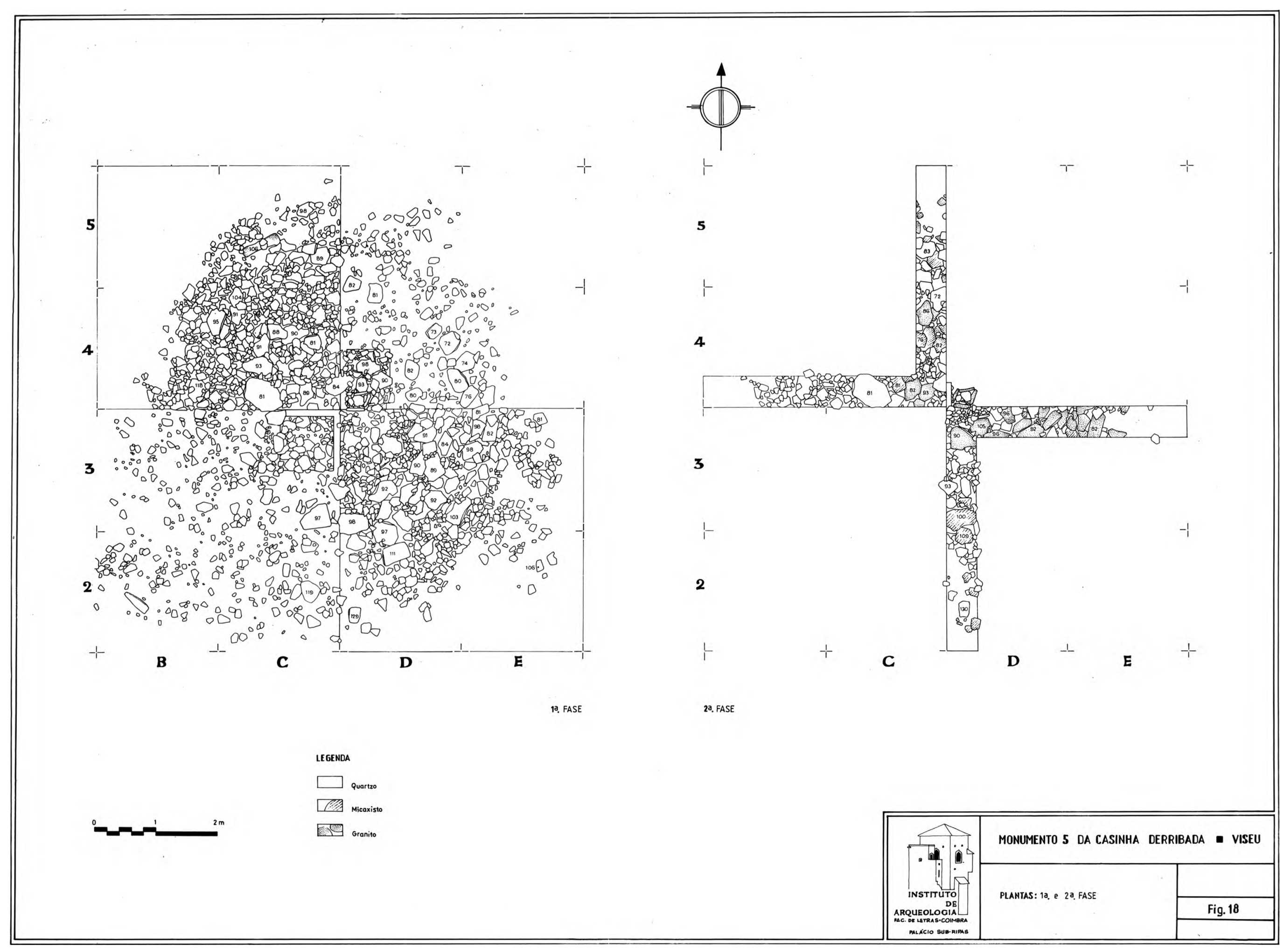


(Página deixada propositadamente em branco) 
esbranquiçada, a que se associavam, por vezes, algumas lajes de granito e micaxisto; perifericamente, os blocos eram mais volumosos, definindo o limite exterior da estrutura (Fig. 18). Por outro lado, observava-se a sua reduzida volumetria, pouco se destacando do relevo natural - c. de $0,35 \mathrm{~m}$ de altura.

A decapagem do quadrante SE revelou ainda, na sua extremidade NO, o topo de uma delgada laje granítica, colocada na vertical, indiciando a existência de uma possível estrutura central. Prolongou-se então a decapagem para as extremidades dos quadrantes $\mathrm{NE}(0,70 \mathrm{~m}$ x $1 \mathrm{~m}$ ) e $\mathrm{SO}$ (quadrado com $0,90 \mathrm{~m}$ de largura).

$\mathrm{Na}$ parte central do monumento tomavam-se visíveis os topos dos elementos pétreos de uma estrutura cistóide, de planta subquadrangular, composta por quatro delgadas lajes graníticas (Fig.

18); não foi localizada qualquer laje que pudesse ter servido de tampa. $\mathrm{O}$ seu interior estava cheio de terra e pedras, por vezes sobrepondo-se às lajes da estrutura que agora aflorava. Este tipo de enchimento, aliás, manteve-se sem grandes alterações até à base $\left({ }^{17}\right)$.

A cista, que terá sofrido, no sentido SE, uma ligeira distorção, provocada talvez pelo esvasiamento do seu conteúdo, apresentava as lajes que a constituíam colocadas quase na vertical e sobrepostas nos seus ângulos. Mediam cerca de $0,30 \mathrm{~m}$ de comprimento e $0,10 \mathrm{~m}$ de espessura média, definindo um espaço subquadrangular com, sensivelmente, $0,40 \mathrm{~m}$ de lado (exterior), e $0,50 \mathrm{~m}$ de altura. No interior, a largura média rondava os $0,25 \mathrm{~m}$. Sobrelevava-se acima do substrato rochoso c. de $0,34 \mathrm{~m}$, penetrando nele os restantes $0,16 \mathrm{~m}$ (Fig. 19; Foto 8).

Após a realização do primeiro registo planimétrico, por desenho, à escala de 1:20, registo fotográfico e cotagem dos blocos mais significativos, seguiram-se os trabalhos de escavação, abrindo-se, para o efeito, quatro sanjas (norte, sul, oeste e este), com $0,50 \mathrm{~m}$ de largura, interceptando-se na parte central do monumento (Figs. 14 e 18). A desmontagem da estrutura pétrea e o desenvolvimento da escavação permitiu a observação interna do tumulus e o seu estudo, com a realização de três perfis longitudinais (Fig. 19).

(17) Este enchimento, após violação do seu conteúdo, poderá ser já relativamente antigo. Ainda assim, fez-se a recolha, a diferentes profundidades, de quatro amostras de terra, visando posteriores análises, nomeadamente a determinação dos teores de fósforo.

Conimbriga, 37 (1998), 5-76 
$\square$ 网

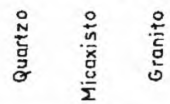

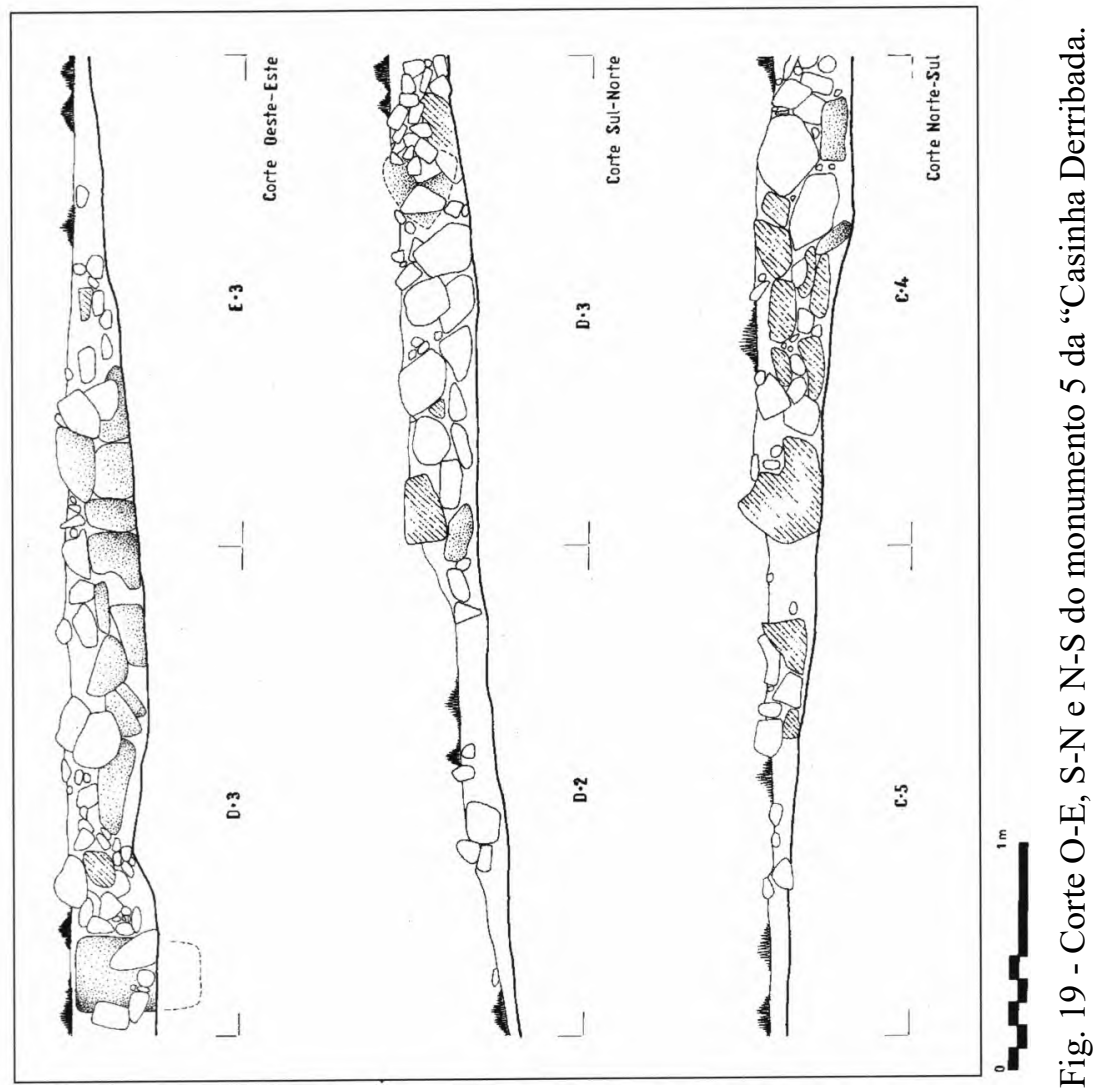




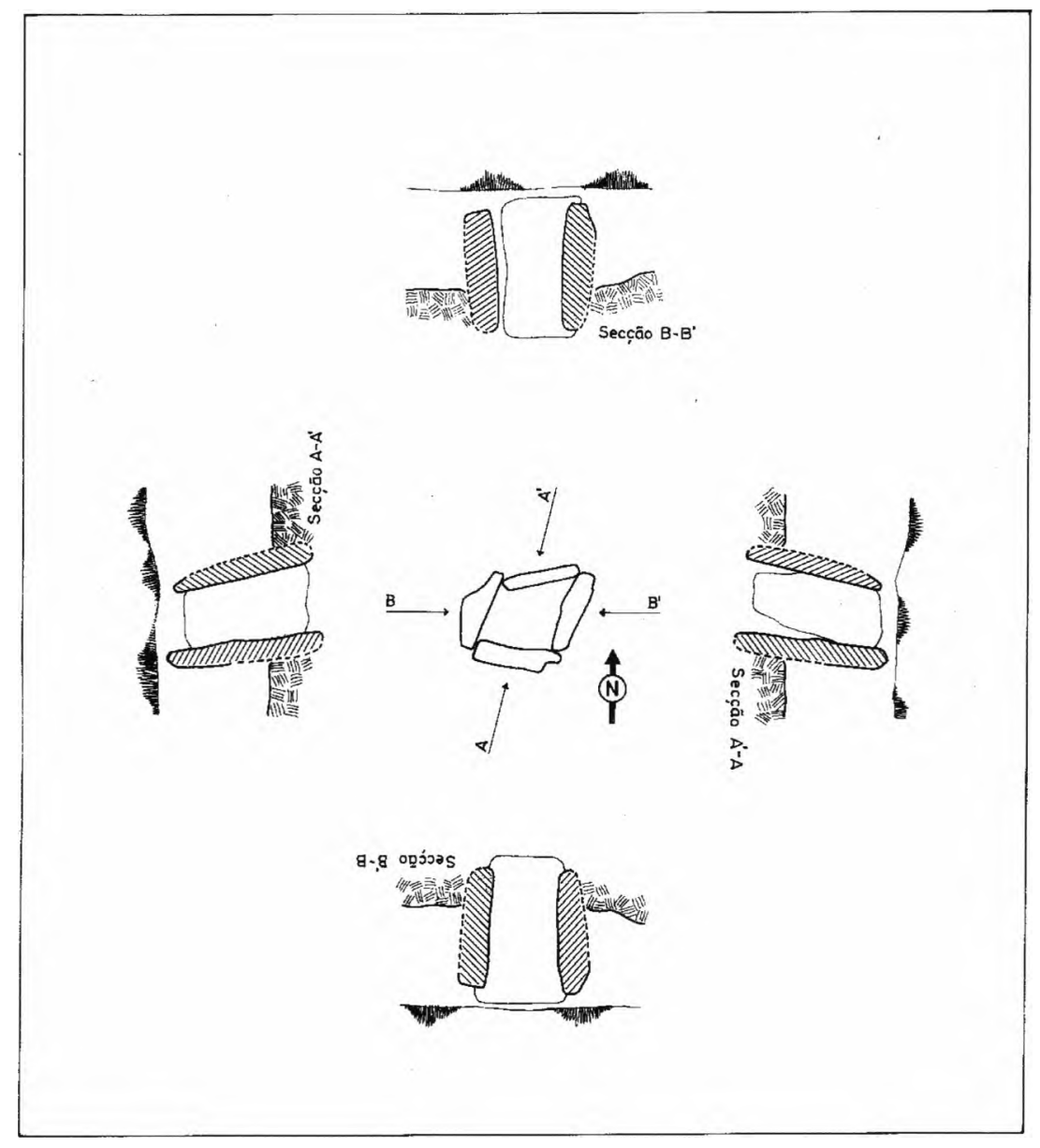

Fig. 20 - Planta da cista ao nível superior e vistas em secção. 
Assim, foi possível identificar, nas sanjas oeste e sul, dois blocos graníticos, de maiores dimensões, colocados em posição oblíqua, acompanhando o pendor do tumulus; o espaço entre estes e as lajes da cista foi preenchido com blocos de quartzo de pequenas dimensões, constituindo uma pequena estrutura de contrafortagem da cista. De assinalar, por fim, que as lajes de granito constituíam a matéria-prima mais utilizada no interior do "cairn", preferenciando-se, aparentemente, os blocos de quartzo e de quartzito para a superfície exterior.

$\mathrm{Na}$ sanja norte, entre o "cairn", recolheu-se um pequeno seixo rolado, em quartzito, de contorno ovalado, com cerca de $3 \mathrm{~cm}$ de eixo maior; provém do quadrado $\mathrm{C} 4$, com as seguintes coordenadas: $\mathrm{x}$ - 1,86 m; y - 0,58 m; z - 1,04 m.

\subsection{A estratigrafía}

O monumento 5, a partir da análise de três perfis, proporcionou uma estratigrafía bastante simples, constituída exclusivamente por uma reduzida camada de terra, superficial, de cor castanho-acinzentado, pulverulenta, por vezes um pouco mais escura e ligeiramente mais compacta nos seus níveis inferiores, terras que, gradualmente, se foram infiltrando por entre as pedras constituintes do "cairn" (Fig. 19).

Assim, face à reduzida possança do corte, não foram efectuadas quaisquer recolhas de amostras de terra para a realização de estudos paleoambientais. Refira-se ainda a inexistência de elementos carbonosos.

\section{Protecção e conservação}

Findos os trabalhos de escavação, em cada um dos monumentos foram realizados trabalhos de protecção e conservação: preenchimento das fossas, no caso dos monumentos 3 e 4, com terra local, previamente isoladas com manga de plástico, reconstituição do tumulus, com terra e pedras, prestando ao monumento o aspecto que apresentava originalmente. De igual modo, no monumento 5 procedeu-se ao enchimento, com terra e pedras, da área escavada; a cista foi cheia, quase na sua totalidade, com terra, de forma a consolidá-la e mantê-la observável.

Conimbriga, 37 (1998), 5-76 


\section{Apontamentos finais}

1.

Os trabalhos desenvolvidos no grupo de monumentos da "Casinha Derribada" permitiram a confirmação do carácter arqueológico destes pequenos montículos de quartzo leitoso e, por isso, eventualmente confundíveis com as aflorações desta rocha, que é abundante neste sector da serra do Mundão.

A dificuldade de identificação prendia-se também com o facto deste tipo de construção não ser habitual do registo arqueológico na região da Beira Alta, não se conhecendo igualmente o seu significado e âmbito cronológico, ainda que desde logo se tivessem relacionado com as pequenas "mamoas" da Fonte da Malga (Cota, Viseu) [Kalb e Hock, 1979].

Mais visíveis com a ocorrência de incêndios nos primeiros anos da década de 90, destacavam-se não tanto pelas dimensões nem pelo volume das suas massas tumulares, extremamente insignificante, mas sobretudo pela ocorrência em terrenos topograficamente pouco acidentados, desprovidos de vegetação - tal como acontecia quando os observámos pela primeira vez —, para além da regularidade dos perímetros das construções e contraste visual provocado pela concentração de blocos de quartzo, de tons claros.

Neste contexto, o monumento 1, implantado junto ao marco geodésico da "Casinha Derribada", de maiores dimensões — c. de 13 metros de diâmetro —, e volumetricamente bastante mais destacado no terreno (aprox. $1 \mathrm{~m}$ de altura), é um pouco discrepante; a topografia do terreno presta-lhe, por outro lado, relativa monumentalidade e um controlo visual de todo o espaço envolvente.

Admitimos inicialmente, no seguimento de A. Girão [1921-22], que se tratasse de um tumulus de cronologia bastante anterior, eventualmente megalítico. Tal hipótese carece de verificação. $\mathrm{Na}$ verdade, apenas as dimensões e volume o sugerem, desconhecendo-se o tipo de estrutura que terá contido; de resto, construtivamente parece enquadrar-se na solução generalizadamente adoptada neste grupo tumular, verificando-se também a utilização profusa da rocha filoniana já referida.

Os restantes monumentos, aliás, embora unidos pela reduzida volumetria, apresentam dimensões variáveis. É de admitir, por isso, que

Conimbriga, 37 (1998), 5-76 
não haja um distanciamento temporal significativo entre este tumulus e os que lhe estão próximos. A confirmar-se esta hipótese, acentua-se a diversidade evidenciada pelos tumuli da "Casinha Derribada", quer quanto às estruturas que encerram, quer quanto às dimensões e volumetria $\left({ }^{18}\right)$.

Para além destes aspectos, será de relevar o facto destas construções terem sido implantadas na cumeada do relevo; de elevada altitude, impõe-se no contexto geográfico local, parecendo haver nisso intencionalidade.

2.

Os monumentos 2, 3, 4 e 5 são externamente semelhantes; com excepção do último, estavam intactos. Estruturalmente podemos considerá-los pequenos "cairns", construídos com a acumulação de pedras, recolhidas nas imediações, com destaque, como dissemos, para o quartzo. Apenas nos monumentos 3 e 4 poderemos falar da existência de um tumulus em terra, mas que na verdade corresponderá a uma pequena acumulação de sedimentos em tomo da laje de cobertura da fossa, no caso do monumento 3 , e dos blocos colocados à volta da cavidade do monumento 4 , sobre os quais foram colocadas as lajes e blocos de pedra que constituem a protecção mais superficial da construção. $\mathrm{O}$ monumento 5 , assim como o 2, correspondem a estruturas inteiramente construídas em pedra $\left({ }^{19}\right)$.

Em todos, utiliza-se como matéria-prima primária o quartzo e o quatrzito, mas também o granito e o micaxisto; o segundo é expressivo apenas no monumento 5. De resto, o quartzo e o micaxisto são aqui materiais abundantes; apenas o granito obrigaria a uma colheita em área um pouco mais distanciada.

(18) Situação que é similar à dos tumuli da "Senhora da Ouvida", no concelho de Castro Daire. Escavações, inéditas, de R. Vilaça e D. J. Cruz (1995).

$\left({ }^{19}\right)$ O monumento 2 da "Casinha Derribada" foi escavado em 1995 por D. J.

Cruz, L. F. L. Gomes e P. M. S. Carvalho. Rei. inédito.

Conimbriga, 37 (1998), 5-76 
3.

Os monumentos 3 e 4 continham no seu interior, sensivelmente ao centro, fossas abertas no substrato: de planta sub-rectangular (contendo um conjunto de quatro vasos), coberta com grande laje insculturada - monumento 3; de pequenas dimensões, de contorno ovalado, pouco profunda, cujo perímetro era definido por blocos de quartzo, contendo terra carbonosa e cinzas, resultantes de fogueira realizada directamente no local, posteriormente encerrada com lajes e blocos de pequenas dimensões similares à da estrutura envolvente - monumento 4.0 monumento 5, uma cista de planta subquadrangular, centrada, formada por quatro delgadas lajes graníticas - denotando regularização —, definindo um espaço interno de abertura reduzida, sensivelmente $0,25 \mathrm{~m}$ de largura e $0,50 \mathrm{~m}$ de profundidade; já remexida, não apresentava laje de cobertura.

A heterogeneidade evidenciada por este grupo de monumentos é ainda mais acentuada se olharmos para o monumento 2, em cujo centro se identificou uma pequena fossa, mas maior que a revelada pelo monumento 3, com as paredes ladeadas por lajes e blocos em posição subvertical. Desconhecemos as características da estrutura contida pelo tumulus 1 , que lhe fica muito próximo.

\section{4.}

Este tipo de construção tumular não é, de facto, tão singular como poderia parecer. Sequentes trabalhos de prospecção conduziram à identificação de outras, com características externas similares, computando-se hoje em cerca de cinco dezenas: três tumuli na Serra da Muna (Campo, Viseu) ( $\left.{ }^{20}\right)$, os núcleos de "Caramêlo" e de "Mazugueira" (Tondela), com três e seis (ou sete) tumuli, respectivamente, o vasto conjunto (cerca de 3 dezenas) da "Senhora da Ouvida" (Monteiras/ Mouramorta, Castro Daire) (21), o núcleo da "Casa da Raposa" (quatro) e o tumulus, aparentemente isolado, do "Pousadão" (Pendilhe, Vila Nova de Paiva).

${ }^{(20)}$ Os monumentos 1 e 2 foram escavados em 1994 e 1995 por D. J. Cruz, R M.

S. Carvalho e L. F. C. Gomes. Rei. inéditos.

(21) Vide nota 18.

Conimbriga, 37 (1998), 5-76 
Anteriormente haviam já sido referenciados os monumentos 2 e 3 de "Moinhos de Vento" (Secarias, Arganil), nas proximidades do dolmen com o mesmo nome (22), e o monumento de "Víbora" (Oliveira do Conde, Carregai do Sal) (23), localizado junto ao marco geodésico com aquela designação, nas proximidades (c. de $750 \mathrm{~m}$ para sul e sul-sudoeste respectivamente) do povoado do Ameal VI e da Orea dos Fiais da Telha, cujas características, pelas descrições feitas, permitem aproximá-los dos monumentos em análise e uma atribuição cronológica, pelo menos genérica, da Idade do Bronze.

Neste contexto integrar-se-á a necrópole de mamoas da "Fonte da Malga" (Cota, Viseu), onde foram identificados seis pequenos montículos de pedra, nas proximidades de dois monumentos megalíticos (24). Um dos tumuli revelou uma cista central feita com quatro lajes de xisto, cuja cronologia, a partir dos fragmentos de um vaso cerâmico, nomeadamente da asa, foi atribuída ao Bronze Final, no âmbito da cerâmica "Baiões/St.a Luzia"; o dolmen simples integraria nas terras do tumulus também uma cista, semelhante à do "cairn", de que se

(22) O monumento 2, com cerca de 7,5 m de diâmetro, era constituído por uma fossa central, cuja escavação atingiu o substrato, medindo $1 \mathrm{~m}$ de diâmetro, desenvolvendo-se "cerca de $90 \mathrm{~cm}$ abaixo do topo do cairn"; era coberta por um cairn central, à base de pedras de quartzito, com 4,5 m de diâmetro. "Uma depressão em forma de coroa circular separava-o de um múrete de terras argilosas com alguma pedra miúda, aquela com cerca de $1,5 \mathrm{~m}$ de largura, enquanto este teria cerca de $2 \mathrm{~m}$ de largura". O monumento 3 seria similar, com fossa central medindo 1,3 $\mathrm{m}$ de diâmetro máximo. Ambos estariam já remexidos. Cfr. Senna Martinez, 1989, pp. 132-136; vide também, Senna Martinez, 1983-84.

(23) “... verificámos existir, aflorando à superfície, num local onde os granitos de base afloram praticamente sem cobertura sedimentar, um "cairn" de pedras de médias dimensões em granito e quartzo, circundado a curta distância por um anel igualmente baixo de pedra. (...) As suas dimensões, calculadas a partir do referido levantamento [topográfico], são cerca de $11 \mathrm{~m}$ no sentido norte/sul por cerca de $9 \mathrm{~m}$ no sentido nascente/ poente. O "cairn" central terá cerca de $4,4 \mathrm{~m}$ por $3 \mathrm{~m}$, com a mesma orientação geral do "monumento", enquanto o anel exterior teria cerca de $1 \mathrm{~m}$ a $1,5 \mathrm{~m}$ de largura". Cfr. Senna Martinez, 1989, pp. 141-142.

(24) Posteriormente, em trabalhos de prospecção, foi identificado pelos autores deste trabalho um novo monumento, um pouco distante do núcleo central; trata-se também de um tumulus com cerca de 7-8 m de diâmetro, muito baixo, aparentemente intacto.

Conimbriga, 37 (1998), 5-76 
observaram alguns vestígios, registando-se, assim, o reaproveitamento de um antigo monumento (Kalb e Höck, 1979; Kalb, 1993).

A necrópole do "Paranho" (Molelos, Tondela), recentemente reestudada, corresponde também a um grupo de seis cistas, semelhantes às da "Fonte da Malga", "Casinha Derribada" (mon. 5) e de "Mazugueira" (mon. 2), integrada em área definida por um semicícrulo de pedras fincadas com $5 \mathrm{~m}$ de diâmetro. $\mathrm{O}$ espólio $\mathrm{e}$ as datações radiocarbónicas entretanto realizadas permitem enquadrá-las no Bronze Final, sensivelmente entre meados do séc. XII a. C. e os finais do séc. XI a. C. e relacioná-las com uma possível exploração agrícola de carácter familiar que poderá ter existido nas proximidades (Cruz, 1997 a) $\left({ }^{25}\right)$.

Será aqui de referir, por fim, a "cista" da "Quinta do Paço", em Moçâmedes (S. Miguel do Mato, Vouzela) que, pela descrição e avaliação de J. Coelho, poderá integrar-se neste contexto $\left({ }^{26}\right)$.

Recentemente, na Beira Baixa, região onde não têm sido identificadas estruturas de carácter funerário atribuíveis ao Bronze Final $\left({ }^{27}\right)$, foram escavadas duas construções, interpretadas como possíveis bases de cabana, com utilização funerária (pelo menos em um dos casos); trata-se do sítio do "Monte de S. Domingos" (Malpica do Tejo, Castelo Branco): o monumento 1 corresponde a uma construção de planta circular, com abertura a SE, feita com lajes fincadas, suportadas exteriormente por blocos e lajes, medindo $3,5 \mathrm{~m}$ de diâmetro, em cuja parte central foi recolhida, para além do reconhecimento da prática de fogo sobre o solo original, uma taça de carena alta e fragmentos de dois outros recipientes; o monumento 2, similar ao anterior, com abertura também a SE, mede $5,5 \mathrm{~m}$ de diâmetro; foram identificadas três acumulações de pedra, duas das quais cobriam vasos cerâmicos,

(25) Vide também Coelho, 1925; Silva e Cunha, 1997; Figueiral, 1997; outras referências em Coelho, 1941 e, sobretudo, 1949: 90-91, onde se publicam fotos do bracelete e fragmentos do pequeno "vaso" de bronze, da cista 2, e do fragmento metálico de uma possível fibula, proveniente da cista 3. Em texto anterior (Cruz, 1997 a), por lapso, não se fez referência a esta documentação gráfica.

(26) "... na Quinta do Paço, a cerca de $20 \mathrm{~m}$ a N. do Tanque das Laranjeiras, apareceram, em 1928, enterradas, 2 pedras, com cerca de $0,60 \mathrm{~m}$, formando ladrilho, sobre o qual havia restos de um vaso de barro vermelho, com terra negra e carvão, resguardada dos lados por 4 pedras ao alto, encostadas nos topos. (v. C. N. A. 7. 16). Deve ter sido uma cista, idêntica às da Necrópole de Paranho". Cfr. Coelho, 1941, p. 429.

(27) Cfr. Vilaça, 1995.

Conimbriga, 37 (1998), 5-76 
nomeadamente uma uma contendo ossos calcinados, associada a uma taça carenada que terá servido de tampa àquela (uma das acumulações), um vaso, em mau estado de conservação (a outra) [Cardoso, Caninas e Henriques, 1997].

\section{5.}

Dos conjuntos identificados, a "Casinha Derribada" aproxima-se diferentemente de uns e de outros. O tipo de constmção, as dimensões e volumetria dos montículos, a disposição no terreno lembram os monumentos que constituem os grupos de "Mazugueira" e "Caramêlo", no concelho de Tondela, como também da "Fonte da Malga", no concelho de Viseu, "Casa da Raposa" e "Pousadão", no concelho de Vila Nova de Paiva, "Senhora da Ouvida", no concelho de Castro Daire.

Decorrem trabalhos de campo e de gabinete sobre alguns destes monumentos, mas, como acima se disse, "Fonte da Malga" revelou pequenos tumuli em pedra, dominantemente de quartzo, em um dos quais se identificou uma pequena cista; em alguns monumentos do "Caramêlo" identificou-se também, por simples observação, uma cista com lajes de granito na sua parte central, e sem dúvida que este tipo de construção se identifica com as "caixas" contidas pelo semicírculo de lajes fincadas do "Paranho" (Tondela).

Mas há, a nosso ver, alguma distância entre estas e as estruturas, por vezes cistóides, da necrópole da "Casinha Derribada". No "Paranho" a mesma construção, pequena, integra várias cistas claramente sepulcrais, certamente relacionáveis com a mesma unidade familiar; nos restantes grupos, os vários tumuli surgem como unidades de um conjunto, ocupando o mesmo espaço sepulcral/ritual. No caso da "Casinha Derribada" é mesmo possível considerar uma certa nuclearização: os monumentos 1 e 2, muito próximos, ocupam o topo do relevo; os monumentos 3 e 4 constituem um pequeno núcleo, na parte central da plataforma; o monumento 5 insere-se isolado, no limite da plataforma, em plano inclinado para SO.

O espaço geográfico é também diverso: no "Paranho" trata-se de uma superfície de encosta, sem grande dominância espacial, parecendo relacionar-se estritamente com o vale $\mathrm{e}$ as terras agrícolas próximas; nos restantes grupos trata-se de cumeadas, ou pequenos "plateaux", de altitude elevada no contexto geográfico regional, sem grandes acidentes

Conimbriga, 37 (1998), 5-76 
topográficos, prestando às construções algum destaque visual, ainda que localizado, mormente pela utilização de materiais constratantes, o mesmo acontecendo com os monumentos de "Moinhos de Vento" (Arganil) e de "Víbora" (Carregai do Sal).

Estes aspectos de diversidade ao nivel regional poderão relacionar-se com o cerimonial específico de cada situação, com a tradição, contactos com outras comunidades, as condições económicas e sociopolíticas de cada comunidade, outros, eventualmente, com a temporalidade. De facto, "Casinha Derribada" e o "Paranho" não são sincrónicos. A primeira parece inserir-se numa tradição, no contexto do Noroeste peninsular, mais antiga, de sepulturas com tumulus de carácter individual, ou de utilização restrita (unidades de um conjunto), da Idade do Bronze, a segunda corresponderá à solução de sepulturas individuais em contexto colectivo, eventualmente relacionável com sociedades tribais organizadas em famílias ou clãs.

6.

A ocorrência de insculturas na laje de cobertura da fossa do monumento 3 é também um aspecto a relevar. Trata-se de uma peça de grandes dimensões, considerando o tipo de material utilizado na construção do "cairn"; depois, foi seguramente laje procurada, e com algum esforço ( $\left.{ }^{28}\right)$, em local algo distante do "Monte Branco".

A laje ultrapassava em muito a abertura da fossa, fechando-a hermeticamente, não permitindo a infiltração de sedimentos. A superfície insculturada é mais ou menos regular, denotando afeiçoamento ou selecção criteriosa. As insculturas correspondem a um reticulado de trama larga, definido a partir de alguns sulcos obtidos por picotagem.

Foi sobre esta laje que se acendeu uma fogueira, de dimensões limitadas, visível na quantidade dos resíduos remanescentes e utilização de lenha de um leque pouco variado de espécies vegetais $\left({ }^{29}\right)$.

$\mathrm{Na}$ região da Beira Alta é conhecida a riqueza de rochas insculturadas, cuja cronologia se estenderá, pelo menos desde os inícios da Idade do Bronze até à Idade Média; os reticulados surgem em alguns destes sítios, nomeadamente no Castro da Cárcoda (Carvalhais, S. Pedro

${ }^{(28)}$ A laje pesará entre 170 e $200 \mathrm{~kg}$.

${ }^{(29)}$ Cfr. Figueiral, 1998. Neste volume.

Conimbriga, 37 (1998), 5-76 
do Sul) e Lufinha (Ribafeita, Viseu) [Silva, 1978b, 1980] (30), como também nos monumentos megalíticos, de cronologia bastante antiga, Dólmen do "Espírito Santo de Arca" (Arca, Oliveira de Frades) e "Casa da Moura" de Pendilhe (V. N. Paiva), mas certamente apostos em data bastante posterior à da sua construção/utilização primária; de facto, as referidas gravuras localizam-se, respectivamente, na face exterior de um dos esteios da câmara e na laje de cobertura da câmara que, como é sabido, não seriam observáveis senão com a degradação do próprio monumento ( $\left.{ }^{31}\right)$; a cronologia deste tipo de figuração é certamente bastante ampla, ainda que com significações distintas, umas vezes com sentido simbólico-religioso, como certamente acontece nos santuários de ar livre da Idade do Bronze / Idade do Ferro, outras, simples instrumento lúdico — "tabuleiros de jogos" — a que se reportarão muitos dos "reticulados" situados em rochedos isolados, povoados da Idade do Ferro, etc. ( $\left.{ }^{32}\right)$.

No Noroeste peninsular este motivo, de resto, surge associado a cistas da Idade do Bronze, não sendo, por isso, tão invulgar a sua ocorrência no tumulus 3 da "Casinha Derribada". Os contextos são imprecisos, pois o seu conhecimento, de um modo geral, resultou de violações ou de trabalhos agrícolas, desconhecendo-se muitas vezes a extensão das necrópoles / isolamento das sepulturas e outras estruturas, dimensões das construções funerárias, espólio, o contexto das lajes insculturadas (paredes, coberturas), etc. ( $\left.{ }^{33}\right)$.

A cista de "As Antas" (Rodeiro, Pontevedra) revelou uma laje, medindo $1,40 \mathrm{~m} \times 1 \mathrm{~m} \times 0,14 \mathrm{~m}$, com um reticulado, de sulcos largos (7 a $10 \mathrm{~mm}$ ), pouco profundos $(2$ a $3 \mathrm{~mm}$ ), formado por sete linhas rectas, paralelas e horizontais, em parte descontínuas, intersectadas por treze outras linhas perpendiculares, de características similares [Vázquez Varela, 1985-86: fig. 2, est. 1 e 2] ; o sepulcro terá fornecido "un puñalito", entretanto perdido, e um vaso cerâmico, de pança suave e colo curto,

(30) Para a Galiza, vide, por ex., Costas Gobema e Novoa Álvarez, 1993; Vázquez Rozas, 1997.

(31) Na Mamoa 4 de Aliviada (Escariz, Arouca) foi também identificada, no 2. ${ }^{\circ}$ esteio do corredor (lado norte), uma representação classificável como "reticulado", mas de facto bastante mais irregular que os que estamos a tratar. Cfr. Silva, 1989.

(32) Cfr. Costas Gobema e Fernandez Pintos, 1985-86; Silva, 1989.

(33) Cfr. Vázquez Varela, 1980.

Conimbriga, 37 (1998), 5-76 
exvasado, de fundo plano [Monteagudo, García Alén e Lois Mejomil, 1981: fig. 20].

Também a cista de "Coitemil" (A Golada, Pontevedra), revelou uma laje decorada, algo mais complexa, associando linhas rectas horizontais e perpendiculares a linhas quebradas e dois grupos de pequenos círculos [Vázquez Varela, 1980a: fig. 3; idem, 1980b].

Generalizadamente este tipo de sepulturas é atribuída ao Bronze Antigo (c. 2200-1800 a.C.), por associação, quando existem, de materiais (vasos, punhais de lingueta, pontas "tipo Palmeia", "braçais de arqueiro", joias, etc.), também provenientes de cistas, como "Taraio" (Malpica, A Coruña) [Peña Santos, 1985], “O Cubillón” (Xermade, Lugo) [Ramil Soneira e Vázquez Varela, 1979), "Agro de Nogueira" (Toques, A Coruña) [Meijide Cameselle, 1993; idem, 1996], “Gandón” (Cangas de Morrazo, Pontevedra) [Peña Santos, 1985], ou de reutilizações de dolmens, como na Mamoa 2 de "A Parxubeira" (Mazaricos, A Coruña) [Rodríguez Casal, 1989].

As "covinhas", um motivo muito mais comum que os "reticulados", surgem também associadas a sepulturas da Idade do Bronze da fachada atlântica: uma das cistas de "Gandón", a de maiores dimensões, cujo espólio é comum a outras sepulturas do Bronze Antigo — "braçal de arqueiro" e placa de cobre com perfuração - estava coberta com uma laje decorada com cinco covinhas; a sepultura da "Quinta da Água Branca" (Lovelhe, Vila Nova de Cerveira) [Fortes, 1906], cuja cobertura, com quatro grandes lajes, era bastante elaborada, revelou também, no exterior da cista, ao nível da sua base, uma laje com "covinhas", em número de 19 numa das faces, e cerca de 9, na face oposta, colocada sobre um amontoado de seixos do rio e um fragmento de xisto [Fortes, 1906, 1907; Cruz, 1991: 107].

No âmbito do "Bronze do Sudoeste" registamos este motivo nas lajes de cobertura da cista 1 da Vinha do Casão (Vilamoura, Algarve) [Gomes, et alii, 1986], cista 23 do monumento 1 (núcleo sul) da Provença [Santos, Soares e Silva, 1974; Silva e Soares, 1981], sepultura 2 de Panóias [Vasconcellos, 1908], monumento V da Atalaia [Schubart, 1965], etc.

São motivos muito simples e, digamos, de todas as épocas, que comportarão certamente significados de cariz simbólico-religioso, variando com o cerimonial próprio de cada contexto - santuários de ar livre, sepulturas, etc. - e de cada época histórica.

$\mathrm{Na}$ "Casinha Derribada" limitamo-nos, por ora a assinalar a

Conimbriga, 37 (1998), 5-76 
sua ocorrência em apenas um dos túmulos, raridade que, aliás, também é comum em muitos outros cemitérios da Idade do Bronze. Mas os sulcos certamente se relacionarão com qualquer simbolismo, difícil de definir, associado ao ritual que conduziu ao acender da fogueira. Podemos admitir que o cerimonial, após a deposição dos vasos e o encerramento da fossa, implicasse qualquer libação e a visualização daquela forma geométrica (tomada evidente pela acumulação de cinzas e carvões nos sulcos), ou tão só a observação das escorrências para as terras periféricas antes da conclusão do tumulus, tal como aconteceria em alguns santuários rupestres pré-históricos onde são comuns os sulcos, "covinhas", meandros, etc., como também nos santuários pré-romanos, onde a existência de altares sacrificiais, tanques, canais, etc., é recorrente. Enfim, o reticulado poderá ligar-se à inviolabilidade do sítio, funcionando como marca simbólica aposta sobre a laje que fechava um espaço que se desejava permanecesse intacto para todo o sempre.

7.

O monumento 3 forneceu quatro recipientes cerâmicos: duas taças fundas, fechadas, de carena alta e fundo plano, e outros dois vasos, de corpo ovoide - num caso aproximando-se dos vasos "bicórneos" abertura estreita, base aplanada e asas de fita; recipientes similares, mas sem asa, são identificados em algumas tipologías sob a designação de "umas" ( $\left.{ }^{34}\right)$. O monumento 4 , como se disse, não forneceu qualquer espólio, cerâmico ou litico; a pequena fossa existente no centro do tumulus estava preenchida apenas com terra carbonosa e cinzas. A cista do monumento 5 não prestou, igualmente, qualquer espólio, embora a situação deste tumulus seja diferente, pois não se conservou intacto até ao momento da escavação; entre as pedras que constituíam o "cairn" recolheu-se um pequeno seixo de quartzito, peça que em alguns contextos tem carácter intencional.

Os vasos da "Casinha Derribada" encontram paralelos genéricos na cerâmica dos povoados do Bronze Final da região, nomeadamente em S. ${ }^{a}$ da Guia (Baiões, S. Pedro do Sul) e St. ${ }^{a}$ Luzia

(34) Ultrapassam o âmbito deste texto as questões relacionáveis com a designação e atribuição funcional das vasilhas cerâmicas pré-históricas. Sobre o assunto vide, por ex., Vilaça, 1995.

Conimbriga, 37 (1998), 5-76 
(Campo/Abraveses, Viseu): as taças, de carenas média e alta, bordos aprumados ou extrovertidos, bases planas ou umbilicadas, com ou sem asas, por vezes com decoração mamilar, são significativas neste "tipo" cerâmico [Kalb, 1978: Abb. 2; Silva, 1986: tipo A2a, est. XLI-8 a 11]; os dois vasos - num dos casos com a ligação do corpo ao colo mais acentuada-, aberturas estreitas, fundo aplanado, aproximam-se do tipo "uma" [Kalb, 1980: Abb. 18], ou das formas fechadas, com pança ovoide, colo alto, fundo plano, uma ou duas asas, neste caso ligando a parte superior da pança à sua parte média [Silva, 1986, est. XLII-2 a 4].

De igual modo, na tipologia de J. C. Senna Martinez [1993], construída a partir de informação recolhida em estações habitacionais, e outras, localizadas a sul do Mondego - "Cabeço do Castro de S. Romão" e "Buraco da Moura de S. Romão" (conc. Seia) -, a similitude formal é até mais estreita: os dois vasos aproximam-se da forma 48 — "potes de colo alto troncoconico fechado" — representada, embora escassamente (2 ex.), no sítio do "Buraco da Moura de S. Romão-20" [1], ambos com decoração incisa pós-cozedura (Senna Martinez, et alii, 1993: est. I - 1 e 2]; as duas taças, com a forma 34 - "taças fundas de carena alta/muito alta" —, fechadas e abertas, com e sem asa de fita, definida a partir de fragmentos de recipientes exumados no "Cabeço do Castro de S. Romão" (sectores A [27] e C [103]) e no "Buraco da Moura de São Romão-20" [1 e 5] (idem, ibidem, est. II].

Mais a sul, já na Beira Baixa, é possível relacionar as taças carenadas da "Casinha Derribada" com o tipo 3 de Monte do Frade (Penamacor, Castelo Branco) [Vilaça, 1995: 125-163, est. CI-3], identificado na camada 3 do sector I, cuja ocupação datará de meados do séc. XIII aos finais do séc. X a. C. [idem, ibidem, pp. 161-162].

No Norte de Portugal encontramos também elementos de referência comparativa, em ambiência e parâmetros cronológicos similares aos da Beira Alta, em numerosos sítios habitacionais [Silva, 1986; Martins, 1987; Jorge, 1988].

Mas nesta região preferimos destacar, pela similitude formal de um dos vasos, mas também pelo contexto - em princípio funerário -, como pelas associações, os achados da "Quinta da Bouça", na freguesia do Bairro (V. N. de Famalicão) [Fortes, 1905-08; Silva, et olii, 1993], onde foram recolhidos quatro vasos, dois dos quais de "largo bordo horizontal" (35), e um outro, morfologicamente muito próximo do

(35) Sobre os vasos de "largo bordo horizontal" e a problemática que suscitam 
vaso 1 da "Casinha Derribada" [idem, ibidem: 256, fig. 2-5 e 9], eventualmente associável ( $\left.{ }^{36}\right)$ a um bracelete maciço de ouro, simples, aberto, de secção circular, terminando com botões rudimentares obtidos por martelagem [Silva, 1986: 255, n. ${ }^{\circ}$ 512, est. CXVI-3; tipo AI (Fase IA); Armbruster e Parreira, 1993: 113, n. ${ }^{\circ}$ 54], associação que também se poderá ter registado nos achados de "Corvilho", em Santo Tirso [Santarém, 1956; Sanches, 1982; Castro Pérez, 1997], cuja cronologia poderá enquadrar-se entre 900 e 700 a.C. [Castro Pérez, 1997: 6] (c. 1100-900 a.C. em anos históricos).

Sem dúvida que também o recipiente cerâmico recolhido na Antela da "Portelagem" (Vila Chã, Esposende), em situação de reutilização de um sepulcro de cronologia antiga (37) aqui pode ser invocado; trata-se de um vaso que se aproxima dos da "Casinha Derribada", pela forma, mas também pela decoração, com quatro protuberâncias mamilares sob o bordo e quatro outras sobre a linha que liga a pança ao colo.

Dentro destas formas regionais, normalmente integradas no amplo grupo dos designados vasos "troncocónicos, subcilíndricos e afins" [Jorge, 1986], certamente de vigência bastante alargada, talvez se possa acrescentar o vaso recolhido no Dolmen das "Carvalhas Alvas" (Parada do Corgo, Vila Pouca de Aguiar) [Leisner, 1958], também um monumento megalítico de grandes dimensões.

Para além do aspecto etnológico da reutilização de sepulcros há muito encerrados, ocorrendo ainda nos finais da Idade do Bronze ( ${ }^{38}$ ), é de destacar a associação destas formas a vasos de "largo bordo", como

veja-se: Soeiro, 1988; Jorge, 1988.

${ }^{36}$ ) Trata-se de achados avulsos dos finais do século passado. O bracelete terá sido recolhido nas suas imediações, a cerca de $100 \mathrm{~m}$. Cfr. Fortes, 1905-08.

$\left.{ }^{(37}\right)$ Monumento escavado por F. Martins Sarmento [1933: 154-156]. Trata-se, de facto, de um monumento megalítico de dimensões medianas, com câmara dolménica, corredor de acesso e massa tumular, a avaliar pelas escavações realizadas em 1989, inéditas. Cfr. Almeida, 1990; Silva, 1994: 166, est. II-2.

${ }^{(38)}$ Referenciamos, no sentido da frequentação destes espaços funerários em tempos bastante tardios, por ex., as peças metálicas da Antela da "Bouça dos Córregos" (Bougado, St. ${ }^{\circ}$ Tirso) - que pertenceram à coleç̧ão do Abade Sousa Maia —, um alfinete, em bronze, com a extremidade proximal decorada com caneluras, e duas argolas, também em bronze, uma das quais incompleta, a outra é aberta, com duas caneluras em cada uma das extremidades, remetendo para momentos bastante avançados do Bronze

Conimbriga, 37 (1998), 5-76 
acontece nos achados da "Quinta da Bouça", acima referidos, mas também em estações da vizinha Galiza, como em "Coto de Laborada" (Calvos de Randín, Ourense) [López Cuevillas, 1930; López Cuevillas e Lourenzo Fernández, 1930; López Cuevillas e Bouza Brey, 1931], onde foram identificados dois grupos de fossas ovoides abertas no saibro, em contexto similar ao de tantos outros sítios do Norte de Portugal com este tipo de vasos, certamente de carácter funerário, distanciados algumas centenas de metros um do outro, cujo espólio era constituído por vasos de corpo ovoide, com asa, aparentados aos de "largo bordo", um dos quais com a aba decorada, associados a vasos globulares, de base plana ou aplanada, com colo curto, bordo levemente esvasado, de abertura estreita, lembrando as formas de que estamos a tratar do Norte e Centro de Portugal ( $\left.{ }^{39}\right)$.

Os vasos de "largo bordo" têm uma distribuição muito regionalizada - litoral do Noroeste peninsular; a sua vigência cronológica, pelo menos em contextos a que pode ser atribuído carácter sepulcral, centrar-se-á nos finais do Bronze Médio e inícios do Bronze Final [Soeiro, 1988; Jorge, 1988], em torno de 1400/1450 a.C, prolongando-se, aparentemente, até aos inícios do I milénio a.C., como parecem indicar as datações relativas à ocupação mais tardia da "Bouça do Frade" (Campeio, Baião) [Jorge, 1988], entre aprox. 900 e 800 a.C. (Quadro III, Fig. 21).

Parece-nos que a realidade que agora se está a identificar na Beira Alta, com o peso da regionalidade que estas manifestações sempre

Final. Cfr. López Cuevillas e Bouza Brey, 1929: 14, est. II; López Cuevillas, 1980: 123. As peças, então em muitos fragmentos, foram restauradas no Museu Regional de Arqueologia D. Diogo de Sousa, cuja colaboração agradecemos.

$\left.{ }^{(39}\right)$ Os vasos de "largo bordo", contrariamente à ideia que os trabalhos antigos podem transmitir, surgem algumas vezes associados a outras formas, como na "Quinta da Bouça", já referenciada (2 vasos de "largo bordo", um vaso "bicónico" com asa, outro de que desconhece a forma), em "Monte da Ola" (Vila Fria, Viana do Castelo), de que se conhece apenas o vaso desta "família", mas originalmente achado em associação com outros dois [Paço, 1933: 272; Soeiro, 1988: 43, fig. XII], ou na necrópole de "Agra de Antas" (S. Paio de Antas, Esposende), onde se exumaram treze vasos de "largo bordo", mas também um pequeno vaso subcilíndrico [Soeiro, 1988: fig. IX-4]; por outro lado, sepulturas tipologicamente similares às que forneceram vasos de "largo bordo", cujo melhor exemplo talvez seja a necrópole de "Agra de Antas" [Ataíde e Teixeira, 1940], continham outras formas cerâmicas, como em "Curvos" (Esposende), uma pequena taça

Conimbriga, 37 (1998), 5-76 
transportam, poderá relacionar-se com o mundo sepulcral e ritual do Noroeste peninsular identificável com os vasos de "largo bordo" e formas associadas (troncocónicos, subcilíndricos, ovoides e subovóides), e outros contextos tumulares, da Galiza e do Norte de Portugal, normalmente atribuídas ao Bronze Antigo, mas onde é possível identificar indicadores de momentos posteriores $\left({ }^{40}\right)$.

Em contexto mais alargado, os recipientes da "Casinha Derribada" identificam-se com formas da designada "Cultura de Alpiarça" [Marques e Andrade, 1974]. O "ar de família” de muitos dos recipientes cerâmicos que ao longo deste século foram recolhidos em tomo do "Castelo" de Alpiarça é evidente, ainda que muitas das formas provenientes dos sítios de "Tanchoal" e "Meijão" sejam mais generalizadamente abertas, com carenas vivas, por vezes marcadas com ressalto, com colo alto e sem asas [Marques, 1972] $\left({ }^{41}\right)$.

Destacamos, neste âmbito, pela analogia formal de algumas das peças, mas sobretudo por terem resultado de trabalhos arqueológicos científicamente conduzidos, os achados do "Cabeço da Bruxa" (Alpiarça, Santarém) [Kalb e Hock, 1981-82].

Destes trabalhos, e do período cronológico abrangente que agora nos interessa, salientamos as "três umas, duas delas comrecipente associado" [idem, ibidem: 67]; trata-se de vasos bicórneos, dois deles com pequeno colo subvertical, de fundo plano ("umas"), associados a taças de carena

de carena alta, perfil aberto e fundo plano [Soeiro, 1988: 40, fig. X], lembrando muito, aliás, as formas cerâmicas do Bronze Final da Beira Alta.

${ }^{(40)}$ Referimo-nos, por exemplo, aos pequenos vasos de base plana, corpo ovoide e colo curto, esvasado, do tipo "A Parxubeira" (Mamoa 2), "Nogueira de Toques", "As Antas", "O Cubillón", "Taraio", etc., algumas vezes associados a artefactos metálicos, ou aos rústicos troncocónicos, por vezes com asa e decoração mamilar, quase sistematicamente atribuídos ao Bronze Antigo. Veja-se, por exemplo, o vaso de "Vila Cova de Perrinho" (Vale de Cambra, Aveiro) [Brandão, 1963; Kalb, 1980: 43, Abb. 7, n. $\left.{ }^{\circ} 41,4\right]$, cuja cronologia será seguramente do Bronze Final, ou as formas designadas "potes" e "potinhos", comuns em povoados do Bronze Final do Norte de Portugal, como S. Julião e Barbudo (Vila Verde, Braga), Santinha (Amares, Braga), Bouça do Frade-tipo 5 (Baião, Porto), etc., ou de povoados da Beira Interior. Cfr. Martins, 1986; Jorge, 1988; Bettencourt, 1995; Vilaça, 1995.

$\left({ }^{41}\right)$ De uma das umas de "Tanchoal dos Patudos" [T26, da tipologia de Marques, 1972], no âmbito do projecto inicialmente referenciado, encontram-se em curso duas datações radiocarbónicas, a partir de ossos humanos e carvão de madeira. De igual modo,

Conimbriga, 37 (1998), 5-76 


\begin{tabular}{|c|c|c|c|c|c|c|c|c|c|c|c|c|}
\hline \multirow[t]{3}{*}{ Ident. } & \multirow[t]{3}{*}{ Ref. Lab. } & \multirow{3}{*}{$\begin{array}{c}\text { Dataçăo } \\
\text { BP }\end{array}$} & \multicolumn{7}{|c|}{$\begin{array}{c}\text { Calibraçäo (AC) } \\
\text { (Pearson e Stuiver, 1993) }\end{array}$} & \multirow[t]{3}{*}{ Tipo de amostra } & \multirow[t]{3}{*}{ Estratigrafia } & \multirow[t]{3}{*}{ Ref. bib. } \\
\hline & & & Thier- & Méto & क्do A & & Mátodo & & & & & \\
\hline & & & cepsăa & Tsigma & 2 sigma & 1 sigma & $\%$ & 2 sigma & $\%$ & & & \\
\hline \multicolumn{13}{|l|}{ Beira Alta } \\
\hline $\begin{array}{c}\text { Paranho } \\
\text { (Molelos, Tondela) } \\
\text { Cista } 4\end{array}$ & GrN-22445 & $3020 \pm 80$ & 1262 & $\begin{array}{l}1392-1331 \\
1329-1124\end{array}$ & $1430-1004$ & \begin{tabular}{|c|}
$1384-1340$ \\
$1323-1155$ \\
$1147-1132$
\end{tabular} & $\begin{array}{c}18 \\
76 \\
6\end{array}$ & 1422-1014 & 100 & \begin{tabular}{|l} 
carvắo vegetal \\
amostra 1
\end{tabular} & conleúdo da cista & Gnz, 1997 \\
\hline $\begin{array}{l}\text { loem } \\
\text { Cista } 1\end{array}$ & GrA-5425 & $2950 \pm 40$ & $\begin{array}{l}1152 \\
1149 \\
1130\end{array}$ & $\begin{array}{l}1254-1242 \\
1214-1111 \\
1104-1060\end{array}$ & $1266-1008$ & \begin{tabular}{|l|}
$1253-1243$ \\
$1213-1112$ \\
$1100-1066$
\end{tabular} & $\begin{array}{l}6 \\
74 \\
20\end{array}$ & $1264-1013$ & 100 & $\begin{array}{l}\text { carvắo vegetal } \\
\text { amostra } 1\end{array}$ & conteúdo da uma & idem \\
\hline $\begin{array}{l}\text { loem } \\
\text { Cista } 2\end{array}$ & GrA.5410 & $2930 \pm 40$ & 1120 & \begin{tabular}{|l|}
$1198-1178$ \\
$1166-1140$ \\
$1140-1032$
\end{tabular} & $1260-998$ & $\begin{array}{l}1195-1182 \\
1164-1141 \\
1139-1035 \\
\end{array}$ & $\begin{array}{c}8 \\
15 \\
77 \\
\end{array}$ & $\begin{array}{l}1258-1234 \\
1224-1001\end{array}$ & $\begin{array}{l}5 \\
95\end{array}$ & $\begin{array}{l}\text { carvăo vegetal } \\
\text { amostra } 3\end{array}$ & conteuido da ctsta & Idem \\
\hline $\begin{array}{l}\text { ldem } \\
\text { Clscia } 2\end{array}$ & GrA-5412 & $2880 \pm 40$ & 1022 & $1117-993$ & \begin{tabular}{|c|}
$1191-1188$ \\
$1161-1143$ \\
$1136-920$
\end{tabular} & $1116-993$ & 100 & \begin{tabular}{|c|}
$1192-1187$ \\
$1162-1143$ \\
$t 137-919$ \\
\end{tabular} & $\begin{array}{l}0 \\
3 \\
97\end{array}$ & $\begin{array}{l}\text { ossos humanos } \\
\text { amostra } 1\end{array}$ & \multirow{2}{*}{ Conteudo da cista } & idem \\
\hline $\begin{array}{c}\text { Idem } \\
\text { Cista } 3\end{array}$ & GrN-22444 & $2790 \pm 60$ & 916 & $999-842$ & $\begin{array}{r}1119-1097 \\
1070-812 \\
\end{array}$ & $\begin{array}{l}994-893 \\
882-848\end{array}$ & $\begin{array}{l}77 \\
23\end{array}$ & $\begin{array}{c}1113-1099 \\
1067-813\end{array}$ & 99 & $\begin{array}{l}\text { carváo vegetal } \\
\text { emostra } 1\end{array}$ & & idem \\
\hline Media ponderada & & $2910 \pm 22$ & $\begin{array}{l}1112 \\
1100 \\
1066\end{array}$ & $1123-1030$ & $\begin{array}{l}1159-1144 \\
1135-1006\end{array}$ & $1117-1042$ & 100 & \begin{tabular}{|l|}
$1159-1145$ \\
$1134-1006$
\end{tabular} & $\begin{array}{l}3 \\
97\end{array}$ & \multicolumn{3}{|l|}{$\begin{array}{l}\text { Teste estatistico o - } 7.32 \\
\text { xi2 (.05) - } 9.49\end{array}$} \\
\hline $\begin{array}{c}\text { St.'Luzia } \\
\text { (Abraveses/Campo. } \\
\text { Viseu) }\end{array}$ & ICEN-485 & $2920 \pm 180$ & 1116 & $\begin{array}{l}392-1337 \\
1329-893 \\
882-848\end{array}$ & $1523-784$ & $\begin{array}{l}1372-1356 \\
1314-909\end{array}$ & $\begin{array}{l}3 \\
97\end{array}$ & \begin{tabular}{|l|}
$1600-1563$ \\
$1531-767$
\end{tabular} & $\begin{array}{l}1 \\
99\end{array}$ & carvăo de madeira & $?$ & Silva, Raposo \& T. Sitva, 1993: 245 \\
\hline Idem & ICEN-486 & $2960 \pm 60$ & $\begin{array}{l}1158 \\
1145 \\
1134 \\
\end{array}$ & $1262-1044$ & $\begin{array}{l}1382-1341 \\
1322-993\end{array}$ & $\begin{array}{l}1260-1291 \\
1229-1111 \\
1105-1058\end{array}$ & $\begin{array}{l}14 \\
65 \\
21 \\
\end{array}$ & $\begin{array}{l}1380-1343 \\
1320-995\end{array}$ & $\begin{array}{l}3 \\
97\end{array}$ & carvăo de madeira & $?$ & idem \\
\hline Tdem & ICEN-469 & $2960 \pm 50$ & $\begin{array}{l}1158 \\
1145 \\
1134\end{array}$ & $\begin{array}{l}1260-1231 \\
1228-1111 \\
1103-1061\end{array}$ & $\begin{array}{l}1372-1359 \\
1314-1003\end{array}$ & \begin{tabular}{|l|}
$1259-1233$ \\
$1226-1113$ \\
$1098-1069$
\end{tabular} & $\begin{array}{l}14 \\
72 \\
13\end{array}$ & $\begin{array}{l}1370-1367 \\
1313-1004\end{array}$ & $\begin{array}{c}0 \\
100\end{array}$ & carvào de madeira & $?$ & idem \\
\hline Toem & ICEN-487 & $2810 \pm 100$ & 927 & $\begin{array}{c}1112-1100 \\
1066-831\end{array}$ & $\begin{array}{l}1260-1201 \\
1228-799\end{array}$ & $\begin{array}{c}1111-1105 \\
1058-833\end{array}$ & $\begin{array}{l}2 \\
98\end{array}$ & \begin{tabular}{|c|}
$1256-1238$ \\
$1219-801$ \\
\end{tabular} & $\begin{array}{l}1 \\
99 \\
\end{array}$ & carvâo de madeira & $?$ & fidem \\
\hline Média ponderada & & $2939 \pm 96$ & 1124 & \begin{tabular}{|l|}
$1250-1250$ \\
$1202-1171$ \\
$1170-1046$
\end{tabular} & $1261-1007$ & $\begin{array}{l}1199-1177 \\
1167-1110 \\
1109-1051\end{array}$ & $\begin{array}{l}15 \\
44 \\
41\end{array}$ & $\begin{array}{l}1258-1235 \\
1224-1013\end{array}$ & $\begin{array}{l}6 \\
94\end{array}$ & \multicolumn{3}{|l|}{$\begin{array}{l}\text { Teste estatistico T-1.93 } \\
\text { x'2 }(.05) \cdot 7.81\end{array}$} \\
\hline $\begin{array}{l}\text { C.C. S. Romáo } \\
\text { (Sola, Guarda) }\end{array}$ & ICEN-198 & $2970 \pm 35$ & \begin{tabular}{|l|}
1196 \\
1181 \\
1165 \\
1141 \\
1139 \\
\end{tabular} & $\begin{array}{l}1258-1234 \\
1225-1121\end{array}$ & $\begin{array}{l}1301-1276 \\
1269-1041\end{array}$ & $\begin{array}{l}1257-1237 \\
122+-1124\end{array}$ & $\begin{array}{l}16 \\
84\end{array}$ & \begin{tabular}{|l|}
$1298-1279$ \\
$1268-1049$
\end{tabular} & $\begin{array}{l}2 \\
98\end{array}$ & carvåo de madeira & C [UE 105] & Senna Martinez, 1989:204-205 \\
\hline Toem & ICEN-197 & $2910 \pm 35$ & $\begin{array}{l}112 \\
1101 \\
1064 \\
\end{array}$ & \begin{tabular}{|l|}
$1150-1150$ \\
$1128-1014$
\end{tabular} & $\begin{array}{l}1252-1246 \\
1208-992 \\
951-949\end{array}$ & $1126-1018$ & 100 & \begin{tabular}{|c|}
$1253-1245$ \\
$1210-991$ \\
$952-947$ \\
\end{tabular} & $\begin{array}{c}1 \\
99 \\
0\end{array}$ & carvâo de madeira & B[UE 15] & frem \\
\hline Média ponderada & & $2940 \pm 26$ & 1125 & \begin{tabular}{|l|}
$1195-1182$ \\
$1164-1141$ \\
$1138-1112$ \\
$1099-1068$ \\
\end{tabular} & \begin{tabular}{|l|}
$1256-1239$ \\
$1218-1025$
\end{tabular} & \begin{tabular}{|c|}
$1197-1179$ \\
$1165-1140$ \\
$1139-1111$ \\
$1104-1059$ \\
\end{tabular} & \begin{tabular}{l|}
13 \\
24 \\
28 \\
35 \\
\end{tabular} & \begin{tabular}{|l|}
$1255-1241$ \\
$1215-1030$
\end{tabular} & $\begin{array}{l}3 \\
97\end{array}$ & \multicolumn{3}{|l|}{$\begin{array}{l}\text { Teste estatistico T- } 1.31 \\
\text { xi2 }(.05)-3.84\end{array}$} \\
\hline Tdem & TCEN-824 & $2680 \pm 80$ & 818 & $902-797$ & $\begin{array}{l}994-765 \\
610-610\end{array}$ & $917-790$ & 100 & $\begin{array}{l}1016-756 \\
684543\end{array}$ & $\begin{array}{c}91 \\
9\end{array}$ & carvào de madeira & B[25] & Senna Martínez, 1991: table 3 \\
\hline $\begin{array}{l}\text { B. Moura S. Romăo } \\
\text { (Seia, Guarda) }\end{array}$ & TCEN-600 & $2770 \pm 90$ & 906 & $1004-818$ & $\begin{array}{l}1153-1148 \\
1130-794\end{array}$ & 999822 & 100 & $\begin{array}{l}1192-1187 \\
1162-1143 \\
1137-791 \\
\end{array}$ & $\begin{array}{c}0 \\
1 \\
99\end{array}$ & carvào de madelra & sala 2 & Senna Martinez, 1998: 127 \\
\hline $\begin{array}{c}\text { S.'da Guia } \\
\text { (S. P. Sul, Viseu) }\end{array}$ & GrN-7484 & $2650 \pm 130$ & 807 & $911-765$ & $\begin{array}{c}1112-1099 \\
1067-405\end{array}$ & $\begin{array}{l}980-962 \\
936-754 \\
689-537 \\
\end{array}$ & $\begin{array}{c}3 \\
62 \\
35 \\
\end{array}$ & $\begin{array}{l}1112-1101 \\
1063-405\end{array}$ & $\begin{array}{c}0 \\
100\end{array}$ & $\begin{array}{l}\begin{array}{l}\text { madeira } \\
\text { do alvado de ponta } \\
\text { de lança }\end{array} \\
\end{array}$ & t: & Kalb, 197477 \\
\hline \multicolumn{13}{|l|}{ Serra da Aboboreira } \\
\hline $\begin{array}{l}\text { Tapado da Caldeira } \\
\text { (Baila, Porto) }\end{array}$ & $\mathrm{KN}-2769$ & $3290 \pm 55$ & 1525 & $1623-1512$ & $1684-1428$ & $\begin{array}{l}1670-1669 \\
1631-1507 \\
1474-1465 \\
\end{array}$ & $\begin{array}{c}0 \\
95 \\
4\end{array}$ & $1680-1496$ & 100 & carvào de madelira & sepultura 1 & Jorge, 1983 \\
\hline Idem & KN-2770 & $3210 \pm 55$ & $\begin{array}{l}494 \\
1486 \\
1450 \\
\end{array}$ & $1519-1416$ & \begin{tabular}{|l|}
$1607-1552$ \\
$1547-1391$ \\
$1333-1327$ \\
\end{tabular} & $1517-1422$ & 100 & $\begin{array}{l}1613-1386 \\
1338-1324\end{array}$ & $\begin{array}{c}99 \\
1\end{array}$ & carvăo de madeira & sepultura 1 & bem \\
\hline Msdia ponderada & & $3250 \pm 40$ & 1516 & \begin{tabular}{|l|}
$1525-1492$ \\
$1488-1449$ \\
\end{tabular} & $1615-1422$ & $\begin{array}{l}1592-1582 \\
1528-1441\end{array}$ & $\begin{array}{l}7 \\
93\end{array}$ & $1611-1425$ & 100 & \multicolumn{3}{|l|}{$\begin{array}{l}\text { Teste estatistico } T-1.00 \\
\text { xi2 }(.05)-3.84\end{array}$} \\
\hline $\begin{array}{l}\text { Tapado da Caldeira } \\
\text { (Baiẫo, Ponto) }\end{array}$ & CSIC-597 & $2990 \pm 50$ & $\begin{array}{l}1254 \\
1243 \\
1213\end{array}$ & $\begin{array}{l}1297-1281 \\
1268-1124\end{array}$ & \begin{tabular}{|l|}
$1388-1335$ \\
$1326-1031$
\end{tabular} & $\begin{array}{l}1297-1280 \\
1268-1124\end{array}$ & $\begin{array}{l}8 \\
92\end{array}$ & $\begin{array}{l}1383-1341 \\
1322-1042\end{array}$ & $\begin{array}{c}7 \\
93 \\
\end{array}$ & carváo de madelira & $\begin{array}{l}\text { 28; lareira; } \\
\text { area contigua à } \\
\text { necropole }\end{array}$ & Jorge, 1985: quadro B, p. 166 \\
\hline $\begin{array}{l}\text { Castelo de Ma1os } \\
\text { (Baián, Porto) }\end{array}$ & OxA-1759 & $2730 \pm 70$ & 843 & $922-809$ & $1010-794$ & 922810 & 100 & $1025-792$ & 100 & sementes carb. & M86-63 & $\begin{array}{l}\text { Hedges, ef al., 1990: } 225 \\
\text { Queiroga \& Figueiral, } 1992\end{array}$ \\
\hline Tdem & OxA-2146 & $2700 \pm 90$ & 827 & $917-799$ & \begin{tabular}{|c|}
$1024-765$ \\
$610-610$
\end{tabular} & $\begin{array}{l}977-964 \\
996-792\end{array}$ & $\begin{array}{c}5 \\
95\end{array}$ & \begin{tabular}{|c|}
$1113-1095$ \\
$1076-757$ \\
$682-545$ \\
\end{tabular} & $\begin{array}{c}1 \\
92 \\
7 \\
\end{array}$ & sementes cart. & M86-51(A16) & 10., idem \\
\hline Tdem & OxA-2147 & $2770 \pm 90$ & 832 & $922-801$ & $1036-767$ & $\begin{array}{l}978-963 \\
937-796\end{array}$ & $\begin{array}{l}6 \\
94\end{array}$ & \begin{tabular}{|c|}
$1118-759$ \\
$676-659$ \\
$699-552$ \\
\end{tabular} & \begin{tabular}{|c|}
96 \\
1 \\
4 \\
\end{tabular} & sementes carb. & M86-347 (A04) & Id. idem \\
\hline Media ponderada & & $2716 \pm 48$ & 835 & $904-812$ & $930-800$ & $\begin{array}{l}897-871 \\
868-819\end{array}$ & $\begin{array}{l}35 \\
65\end{array}$ & $\begin{array}{l}975-965 \\
995-799\end{array}$ & $\begin{array}{c}1 \\
99 \\
9\end{array}$ & \multicolumn{3}{|l|}{$\begin{array}{l}\text { Teste estatistico T'-0.7 } \\
\text { xi2 }(.05)-5.99\end{array}$} \\
\hline $\begin{array}{l}\text { Bouça do Frade } \\
\text { (Baalao, Ponto) }\end{array}$ & CSIC- 30 & \begin{tabular}{|l|}
$2720 \pm 50$ \\
\end{tabular} & 837 & $907-813$ & $\begin{array}{l}978-963 \\
937-800\end{array}$ & $899-821$ & 100 & $\begin{array}{l}980-961 \\
999-800\end{array}$ & $\begin{array}{c}3 \\
97 \\
\end{array}$ & carvăo de madeira & sector IIA, cam. 3 & Jorge, 1988: $63-64$ \\
\hline Idem & C्SIC-631 & $2720 \pm 50$ & 837 & $907-813$ & $\begin{array}{l}978-963 \\
937-800\end{array}$ & 899821 & 100 & $\begin{array}{l}980-961 \\
939-800\end{array}$ & \begin{tabular}{|c|}
3 \\
97 \\
\end{tabular} & carvăo de madeira & sector IIA, cam. 3 & Idem \\
\hline Toem & CSIC-632 & $2710 \pm 50$ & 832 & $902-809$ & 929798 & $\begin{array}{l}897-872 \\
865-814\end{array}$ & $\begin{array}{l}32 \\
68 \\
\end{array}$ & $\begin{array}{l}975-966 \\
935-797\end{array}$ & $\begin{array}{c}1 \\
99\end{array}$ & carvăo de madeira & sector IIA, cam. 3 & Idem \\
\hline Média ponderada & & $2717 \pm 30$ & 836 & $\begin{array}{l}897-870 \\
869-820\end{array}$ & $911-808$ & $\begin{array}{l}896-875 \\
859-821\end{array}$ & $\begin{array}{l}34 \\
66 \\
\end{array}$ & $906-811$ & 100 & \multicolumn{3}{|l|}{$\begin{array}{l}\text { Teste estatlstico T' - .03 } \\
\text { xi2 (.05) - } 5.99\end{array}$} \\
\hline $\begin{array}{c}\text { Lavra } \\
\text { (M. Canaveses, Porto) }\end{array}$ & TCEN-414 & $2980 \pm 70$ & \begin{tabular}{|l|}
1251 \\
1248 \\
1205 \\
\end{tabular} & \begin{tabular}{|l|}
$1307-1112$ \\
$1102-1062$
\end{tabular} & $1402-993$ & $\begin{array}{l}1304-1271 \\
1270-11+3 \\
1098-1068\end{array}$ & \begin{tabular}{|l|}
12 \\
78 \\
10 \\
\end{tabular} & $\begin{array}{l}1392-1331 \\
1329-1004\end{array}$ & $\begin{array}{l}10 \\
90\end{array}$ & carvalo de madelira & 85. P5. Lar. 5 & Sanches, 1995: 116 \\
\hline Toem & CSIC-824 & $2665 \pm 60$ & 811 & $841-798$ & $915-772$ & $\begin{array}{l}805-876 \\
857-794\end{array}$ & $\begin{array}{l}17 \\
83\end{array}$ & $\begin{array}{l}983-969 \\
941-761 \\
671-669 \\
627-595 \\
575-567 \\
\end{array}$ & \begin{tabular}{|c|}
1 \\
97 \\
0 \\
2 \\
0 \\
\end{tabular} & carvăo de madeira & P5, 2. C., Lar. 5 & Idem \\
\hline Tdem & OxA-5434 & $2675 \pm 50$ & 816 & 841802 & $910-791$ & $\begin{array}{l}894-879 \\
850-799 \\
\end{array}$ & \begin{tabular}{|l|}
15 \\
85 \\
\end{tabular} & $915-786$ & 100 & grăo "triticum" carb. & 88. cam. 3a & Ińsdita \\
\hline $\begin{array}{l}\text { Media ponderada } \\
\text { (CSIC-824+OXA-5434) }\end{array}$ & & $2671 \pm 39$ & 814 & $833-803$ & $899-795$ & $843-799$ & 100 & $\begin{array}{l}897-870 \\
870-795 \\
\end{array}$ & $\begin{array}{l}14 \\
86 \\
\end{array}$ & \multicolumn{3}{|l|}{$\begin{array}{l}\text { teste estatistico } T^{\prime}-.02 \\
\text { Xi2 }(.05)-3.84 \\
\end{array}$} \\
\hline
\end{tabular}


(Página deixada propositadamente em branco) 
alta, também de fundo plano, uma das quais com aplicação mamilar, recolhidos, em dois casos, em "covas funerárias" [idem, ibidem: 68] abertas no solo original, uma com $0,30 \mathrm{~m}$ de profundidade, a outra, com $0,60 \mathrm{~m}$, preenchidas com barro compacto e fechadas, num caso, por "um montículo de pedras brancas" [idem, ibidem], noutro, por "três únicas pedras que restaram da cobertura sepulcral" [idem, ibidem]; numa das fossas os vasos associavam-se ao fragmento de um bracelete de bronze. A terceira "uma" foi recolhida sem que tenha sido possível definir o contexto exacto em que se encontrava, admitindo-se que "um possível recipiente associado ou não existia ou já tinha desaparecido" [idem, ibidem] e que a associação ao grupo de "cinco braceletes de bronze" recolhidos posteriormente nas suas proximidades (20 a $40 \mathrm{~cm}$ afastada da uma e à mesma cota) seja "altamente provável" [idem, ibidem].

De resto, no àmbito dos "mundos" de "Alpiarça/Lapa do Fumo", como também das produções cerâmicas do "Bronze do Sudoeste" estes tipos são recorrentes [Marques e Andrade, 1974; Schubart, 1975] $\left({ }^{42}\right)$, denotando um extenso fundo cultural comum.

$\mathrm{Na}$ área mais continental do designado "Bronze do Sudoeste", referenciamos, por exemplo, as necrópoles de cistas de "tipo Huelva", em especial as do grupo mais ocidental (serras de Aracena, Huelva; vale de Tejada, Sevilha), associada a taças semiesféricas ou carenadas, como acontece em Castañuelo I e La Ruiza (Huelva) e Cortijo de Chichina (Sanlúcar la Mayor), datadas do Bronze médio (1500/1400-1100 a.C., convencional) ou dos seus finais (c. 1300 a.C., convencional) [Amo de la Hera, 1975 a e b; Fernández Gomez, et alii, 1976], relacionando-se estreitamente com os sepulcros do Algarve, Baixo Alentejo e das províncias de Cáceres e Badajoz.

Neste contexto, mas um pouco mais a leste, constituindo, talvez, a "fronteira" mais oriental daquela "cultura", em conexão com as formas cerâmicas das cistas "tipo Huelva" (Becerrero I, Beas, Cortijo de Chichina, La Ruiza), referenciamos os vasos ovoides dos estratos $\mathrm{XV}, \mathrm{XIV}, \underline{\mathrm{XTTT}}$ (base) do povoado de Setefilla (Sevilha) e, particularmente,

temos em curso uma análise radiocarbónica dos ossos da sepultura de inumação de "Agra de Antas" (S. Paio de Antas, Esposende), cujos restos osteológicos foram estudados por

A. Ataide e C. Teixeira [1940].

${ }^{(42)}$ Vide também, para materiais mais recentemente publicados (Capela de S. Pedro, Sintra; Lapa do Fumo, Sesimbra; Abrigo das Bocas, Rio Maior, etc.), Carreira, 1994.

Conimbriga, 37 (1998), 5-76 


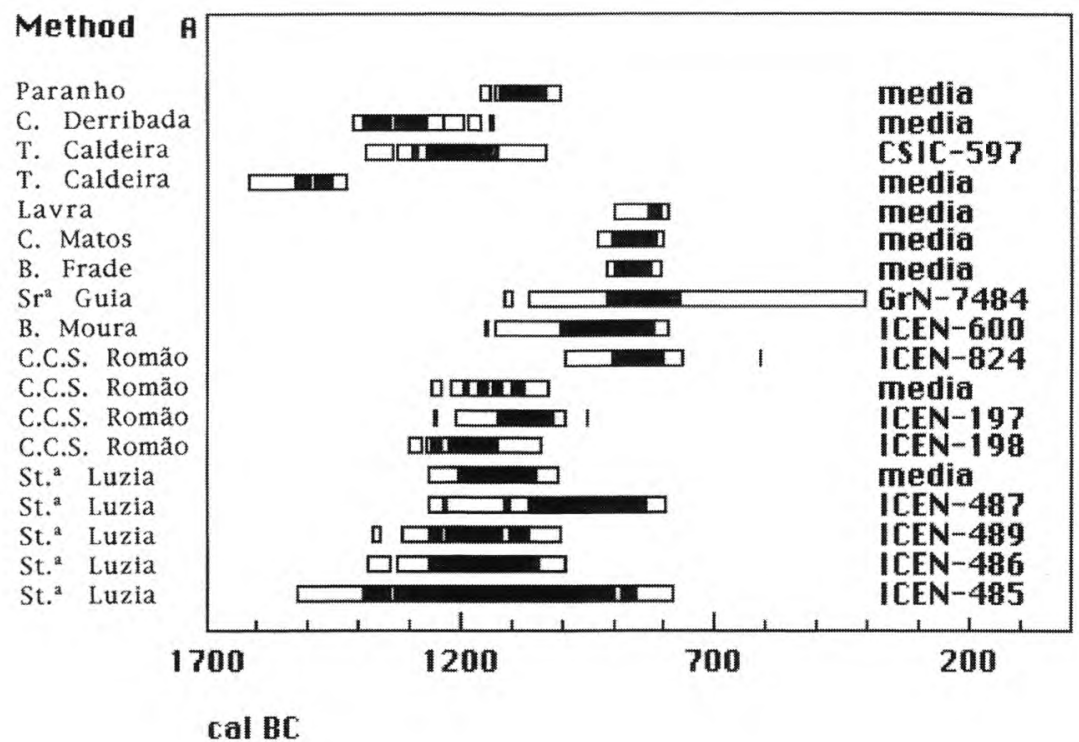

Fig. 21 - Representação gráfica das datações radiocarbónicas calibradas de contextos habitacionais, funerários e/ou cultuais da Beira Alta e do Norte de Portugal. Período convencional "Libby" de 5568 anos, intervalos de confiança de \pm 1 sigma $(68,26 \%)$ e \pm 2 sigma (95,46\%). "Radiocarbon Calibration Program, rev. 3.0.3c", Quaternary Isotope Laboratory, University of Washington, com curva de 20 anos (seg. S tui ver e Reimer, 1993). Método A. Vide Quadro III. 
da sepultura de inumação múltipla (de pelo menos 3 indivíduos), aberta no estrato XIV, onde se recolheu uma "uma", de corpo globular e abertura estreita, associada a artefactos metálicos (espada/estoque, alabarda e punhal) [Aubet Semmler, 1981: 129; Aubet Semmler et olii, 1983: figs. 15 a 21], cuja vigência se situará entre c. 2000-1600 a. C.) $\left({ }^{43}\right)$.

Para além da similitude formal, interessa-nos sobretudo destacar a associação de vasos (de um certo tipo de vasos) e taças ou "cuencos", estes últimos servindo, por vezes, como tampas, como será o caso do "Cabeço da Bruxa", "Castañuelo", ou das estruturas do "Monte de S. Domingos", já na Beira Baixa.

A análise das cerâmicas da "Casinha Derribada" presta-nos a impressão de que, ainda que genericamente relacionáveis com as produções do Bronze Final da Beira Alta, e áreas conexas, como o Norte de Portugal, traduzem algum arcaísmo, visível nos perfis fechados e carenas altas das taças, corpo ovoide e abertura muito fechada dos vasos.

8.

Para além destes indicadores de carácter relativo, a cronologia da necrópole da "Casinha Derribada" pode, por ora, ser definida com datações radiocarbónicas realizadas com materiais lenhosos carbonizados recolhidos sobre e em tomo da laje de cobertura da fossa do monumento

3. Esta situar-se-á sensivelmente entre 1400 e 1150 a.C., correspondendo aos finais do Bronze médio / inícios do Bronze Final (Fig. 13).

Neste sentido, as construções deste grupo e, eventualmente de alguns outros já identificados, poderão relacionar-se genericamente com os povoados de altura da região, alguns evidenciando indícios de "fortificação", ou com os habitats de dimensões e estruturação económica e social distintas, de que se dispõe de informação bastante mais reduzida

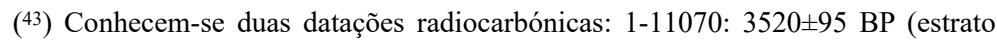
XIV) e 1-11069: 3470195 BP (estrato XIII). Cfr. Aubet Semmler, 1981: 129; idem, et alii, 1983: 48-49]. Os resultados são estatisticamente semelhantes, correspondendo ao mesmo contexto cultural. Média ponderada: 3495168 BP, cuja calibração fornece um intervalo máximo situado entre 1974 e 1631 cal. AC. Calibração realizada com o "Radiocarbon Calibration Program rev. 3.03.c" (Cfr. Stuiver e Reimer, 1993) com curvas de 20 anos (Cfr. Pearson e Stuiver, 1993).

Conimbriga, 37 (1998), 5-76 
(muitos desses habitats não serão mais que pequenas aldeias atribuíveis a famílias extensas), relacionados com aqueles $\left({ }^{44}\right)$.

De facto, povoados de altura, como "St." Luzia" (Viseu) e "Cabeço do Castro de S. Romão" (Seia) terão começado a ser ocupados aproximadamente entre 1250 e 1000 a. C; nos inícios do séc. VIII a. C. este tipo de habitat estará ainda em vigência, como parecem indicar as datações obtidas para o "Cabeço do Castro de S. Romão", "S.a da Guia" (S. Pedro do Sul) ( $\left.{ }^{45}\right)$, para além do abrigo sob rocha do "Buraco da Moura de S. Romão" (Seia), cuja funcionalidade poderá ser discutível (Quadro EH; Fig. 21). Também a ocupação do Bronze Final de "Monte do Frade" terá começado em meados do séc. XIII a. C., com abandono durante o sec. $\mathrm{X}$ a. C. $\left({ }^{46}\right)$.

Estes ditâmes cronológicos não estão, como vimos, distantes dos que poderiam ser considerados com relatividade a partir da cultura material. De facto, os vasos exumados no monumento 3 da Casinha Derribada identificam-se genericamente com formas de alguns destes povoados, sobretudo do "Cabeço do Castro de S. Romão".

O povoado de "St. ${ }^{a}$ Luzia" está distante, em linha recta, um pouco mais de $5 \mathrm{~km}$ da "Casinha Derribada, não parecendo, em termos territoriais $\left({ }^{47}\right)$, relacionar-se directamente com esta "capital" do Bronze Final da Beira Alta.

No "Monte Branco" não foram localizados quaisquer vestígios de ocupação habitacional, nem mesmo as pedras-de-mó que muitas vezes aparecem integradas nas massas tumulares das construções sepulcrais; a "Casinha Derribada", assumindo o papel de espaço funerário-religioso, situar-se-á, talvez, algo distante do povoado, no vale de Póvoa de Mundão

$\mathrm{t}^{44}$ ) Sobre a ocupação da Beira Alta no Bronze Final e períodos subsequentes, modelo que seguimos de perto neste e em texto anterior (Cruz, 1997 a), vide Alarcão, 1996 a e b.

$\left.{ }^{45}\right)$ A datação da S. ${ }^{a}$ da Guia (GrN-7484) apresenta um desvio-padrão muito elevado, com limites, após calibração, extensos. Seguimos, a título meramente indicativo, o resultado calibrado para o intervalo de confiança de \pm 1 sigma (c. 68,26\%), conjugado com os indicadores cronológicos dos restantes sítios, da Beira Alta e do Norte de Portugal.

(46) Conhecem-se para a ocupação do Bronze Final do Monte do Frade quatro datações: ICEN-969: 2920150 BP (início da ocupação) e ICEN-970: 27801100 BP (ocupação inicial, um pouco posterior); GrN-19660: 2805115 BPeICEN-971: 2850145 BP, permitem definir o terminus ante quem da ocupação. Cfr. Vilaça, 1995: 161-162.

${ }^{(47)}$ Cfr. Alarcão, 1996 a, sobretudo pp. 8 a 17 e cartas 1 e 2. Considerando o 
onde as terras são propícias à exploração agrícola, com relações, ou talvez não, com "St. " Luzia".

A avaliar pelas datações radiocarbónicas disponíveis, como também as formas cerâmicas e os materiais metálicos, as cistas do "Paranho" parecem relacionar-se mais directamente com as populações do aro dos povoados de altura da região.

Neste sentido, embora os indicadores cronológicos sejam latos, admitimos, como dissemos relativamente ao espólio, que o grupo da "Casinha Derribada" se identifique com populações um pouco anteriores à emergência daqueles povoados. A ser certa esta asserção, poderiam pertencer aos casais das proximidades. Neste sentido, os cultos no alto do monte, a propósito da morte, ou outras manifestações de índole simbólico-religiosa, poderiam funcionar como factor agregador destas populações dispersas. Haveria assim uma dissociação dos espaços habitacionais (implantados nos vales ou nas superfícies de encosta) e os de carácter sagrado, actuando as cumeadas dos montes como limites naturais das explorações agrícolas de povos limítrofes $\left({ }^{48}\right)$.

Será no entanto de dizer que a impressão "barroquizante" do espólio cerâmico da "Casinha Derribada" poderá porventura derivar do carácter "periférico" da população que construiu estes túmulos, não utilizadora da cerâmica mais esmerada de St. ${ }^{a}$ Luzia. Enfim, as comunidades poderiam, em rigor, ser contemporâneas (coexistência de povoados de altura e de casais), mas a distância, geográfica, económica e sociopolítica seriam também marcantes.

\section{9.}

Um último aspecto que gostaríamos de acentuar nesta notícia preliminar sobre os monumentos 3,4 e 5 da "Casinha Derribada" relaciona-se com a funcionalidade das diferentes estruturas identificadas: uma cista e duas fossas, uma contendo vasos, outra apenas cinzas e terra carbonosa.

Contrariamente às fossas dos povoados e das necrópoles do

percurso de uma hora de marcha, a "Casinha Derribada" estaria nos limites do território de St. ${ }^{\mathrm{a}}$ Luzia assim definido.

(48) "Talvez as trocas de bens entre os casais fossem raras e cada célula social vivesse num estado de autarcia económica, provendo ao seu próprio sustento. Mas é

Conimbriga, 37 (1998), 5-76 
Noroeste peninsular, cuja funcionalidade foi acesamente discutida em tempo recente [Jorge, et alii, 1980; Silva, 1985; Jorge, 1988], eremos que não haverá grandes dúvidas de que na "Casinha Derribada" não estaremos em presença de "silos" ou "fossas detríticas", relacionáveis com habitats. Têm, certamente, um carácter funerário e ritual, e este deve ser visto de uma forma bastante mais aberta do que normalmente acontece com a análise deste tipo de estruturas, ou seja, um cemitério comportará, certamente, outro tipo de construções que não apenas as que relacionam directamente com os restos mortuários. Trata-se, de facto, de estruturas de funcionalidade diversificada, integradas num complexo de gestos simbólicos, relacionáveis com a morte e outros comportamentos de ordem simbólico-religiosa, ou tão-só sociais. Será assim de admitir que algumas das estruturas tenham recebido corpos, por inumação, ou cinzas, mortuárias ou não, ou tão só oferendas, relacionáveis com aqueles.

Esta situação, aliás, não é tão invulgar como poderia parecer. No Sudoeste foram escavados diversos cemitérios da Idade do Bronze, de cistas e de fossas, que integravam outras estruturas, nomeadamente lareiras, de diferentes tipos, por vezes agrupadas, muito perto ou distanciadas das sepulturas, de tipologia e dimensões diversificadas, como acontecia na Vinha do Casão [Gomes, et olii, 1986]; as lareiras de maiores dimensões, "em poço", evidenciavam "sucessivas reutilizações" e restos alimentares [idem, ibidem: 71], parecendo apontar no sentido da frequentação destes sítios, que não são apenas "depósitos" de mortos.

As lareiras também ocorrem no povoado do Pessegueiro (Sines), nas imediações de um núcleo sepulcral, eventualmente relacionáveis com o habitat [Soares e Silva, 1981: 170], o mesmo acontecendo com a necrópole de Cortijo de Chichina (Huelva) (Gómez, Mata e Fernández, 1976: 373-374]. No Norte de Portugal destacamos o sitio do Tapado da Caldeira (Baião), ainda que a correlação temporal dos diferentes vestígios aqui identificados seja difícil de estabelecer [Jorge, 1980], sugerindo-se a existência de um "espaço funerário e cultural" comportando "testemunhos de índole diversa" [Jorge, 1985: $166]$.

Quanto à diversidade do ritual, Amo y de la Hera [1975a], por exemplo, referindo-se às cistas de Huelva concluía, um pouco incredulamente, que "resulta sorprendente que después de excavar casi

evidente que os casais tinham que relacioar-se uns com os outros, quanto mais não fosse para trocarem cônjuges" [Alarcão, 1996 b: 15].

Conimbriga, 37 (1998), 5-76 
un centenar de tumbas en las necróplis de El Becerrero y El Castañuelo no hayamos encontrado en ellas ningum resto óseo (...), tampoco aquéllas que aparecieron intactas (...) [nem também ] restos de cenizas" [p. 438], o que o levava a afirmar "que en El Becerrero y El Castañuelo no se utilizó ni la inhumación ni la incineración dentro das cistas" [p. 439]. Outros grupos (Beas e La Ruiza) revelaram inumações secundárias, nomeadamente do crânio. Algumas, apesar de intactas, não revelaram qualquer espólio. No túmulo A de Setefilla as "umas" surgem dissociadas das inumações, relacionando-se com a armazenagem de alimentos [Aubet Semmler, 1981: 156].

Esta diversidade de situações, ao nível da arquitectura, orientação das sepulturas, disposição e orientação dos corpos, composição do espólio (ou ausência dele), dimensões dos tumuli, etc., é observável em muitos outros cemitérios da Idade do Bronze $\left.{ }^{49}\right)$.

Cabe aqui referir, já no Noroeste, a necrópole de "Agro de Nogueira" (Toques, A Coruña) que revelou um complexo de estruturas; de facto, "en un espacio reducido coexistían diferentes soluciones constructivas y rituales" [Meijide Cameselle, 1996: 218]:

- urna cista, intacta, incrustrada na rocha de base, feita com 6 lajes em posição vertical, definindo um espaço de planta poligonal, de pequenas dimensões (c. 1,20 m x 0,80 m x 0,50 m), superficialmente assinalado com um pequeno amontoado de pedras que incluía um elemento móvel de moinho manual, sob o qual se dispunham as 9 lajes de cobertura, parcialmente sobrepostas; a sua escavação forneceu um vaso, similar a outros exumados em cistas e reutilizações de dolmens, a que, na Galiza, se adscreve uma cronologia do Bronze Antigo ${ }^{(50}$ );

(49) Cfr., entre outros, Schubart, 1971, 1975; Silva e Soares, 1981; Gomes, et alii, 1986; vide também, por ex., para contextos um pouco anteriores, Fábian Garcia, 1995.

${ }^{(50)}$ Cremos que, para além da associação a certo tipo de artefactos metálicos, se segue muito estritamente L. Monteagudo [1977], defensor de uma origem centro-europeia ("Cultura do Ródano") para este tipo de vasos, atribuído ao Bronze Antigo. É certo que a cultura material desta região da Península Ibérica mostra uma "fácies" muito particular, em momento um pouco impreciso, talvez a partir dos finais do III milénio a. C. até meados do II milénio a. C. (convencional) [Fábregas Valcarce, 1991: 90], com a presença de artefactos perfurados (maças, machados e enxós de duplo gume), os cinzéis de grandes dimensões, etc., cuja origem poderá situar-se em áreas muito amplas da Europa, seja a

Conimbriga, 37 (1998), 5-76 
- uma outra cista, de menores dimensões $(0,70 \mathrm{~m} \times 0,25 \mathrm{~m})$, escavada na rocha, feita com numerosas lajes fincadas, de planta aproximadamente rectangular; apresentava na base um lajeado e a cobertura era feita com um amontoado de pedras; a sua escavação revelou restos humanos cremados, pertencentes a um adulto do sexo feminino;

- oito fossas escavadas no saibro, de planta ovalada e subcircular, de reduzida profundidade $(0,20 \mathrm{~m}$ a $0,30 \mathrm{~m})$ definidas exteriormente por concentrações, mais ou menos densas, de pedras; o seu enchimento era constituído por terra, com pequenos carvões e pedras dispersas; foram interpretadas como inumações simples, ainda que com base em indícios escassos ;

- uma fossa, de planta circular, com cinzas no seu interior, vista como possível sepultura de incineração ou com "los restos de un hogar, relacionado con el ritual funerario" [p. 226].

Para além da diversidade de estruturas integrando o mesmo complexo que, cremos não deverão relacionar-se com o habitat, o próprio autor releva a "coexistencia de los ritos de cremación e inhumación", justificados, como os restantes elementos, com diferenças de estatuto, sexo, idade, etc. (p. 226).

Infelizmente, a informação sobre os cemitérios da Idade do Bronze do Noroeste é muito limitada, circunscrevendo-se ao achado casual, sem escavação da área circundante. Mas em "Camota" (A Coruña) haveria outras cistas, para além da que revelou um punhal de lingueta e um braçal de arqueiro [Luengo Martínez, 1965; Ruiz-Gálvez Priego, 1979: 153] e em "Gandón" (O Morrazo, Pontevedra), foram escavadas duas cistas, uma das quais, pequena, com restos de uma cremação (51), sem outro espólio; a outra, maior, coberta com grande laje, forneceu um braçal de arqueiro e uma placa de cobre com perfuração [Peña Santos, 1985].

É também evidente a diversidade nos cemitérios de fossas no Noroeste, fornecedores de vasos de "largo bordo", troncocónicos e afins,

ocidental, como considera Fábregas [idem, ibidem: 268], ou mais continental. Estes contactos longínquos com a Europa, que poderão justificar na Galiza o designado "horizonte de Rechaba" [Vázquez Varela, 1979], não são necessariamente extensíveis àquele tipo de vasos, cujos protótipos podem situar-se na própria Península Ibérica. Vide nota 40.

(51) Para este aspecto vide Meijide Cameselle, 1996: 230.

Conimbriga, 37 (1998), 5-76 
particularmente ao nível da composição do espólio: cistas e fossas poderão apenas conter um vaso, como acontecia em algumas das sepulturas de "Agra de Antas" (S. Paio de Antas, Esposende) [Ataíde e Teixeira, 1940] e do "Belinho" (S. Paio de Antas, Esposende) [Soeiro, 1988: 36], ou nas fossas semiovóides de "Faísca" (Caldeias, Guimarães) [Cardozo, 1936], e nas sepulturas planas de "Barqueiro" (S. Cláudio do Barco, Guimarães) [idem, ibidem: 84]; mais do que um vaso, como em "Agra de Antas" e nas fossas (sepulturas planas) de "Coto da Laborada" (Calvos de Randin, Ourense) [López Cuevillas, 1930; López Cue villas e Lourenzo Fernández, 1930; López Cuevillas e Bouza Brey, 1931]. Há ainda as sepulturas que são de diferentes dimensões, claramente de inumação, como em "Agra de Antas", acompanhadas de um ou mais vasos de "largo bordo", e as fossas de "Faísca", sem restos osteológicos, contendo um vaso daquele tipo cerâmico, sob os quais, em alguns casos, se dispunham "filões de cinzas e carvões, à mistura com terra" [Cardozo, 1936: 72].

"Casinha Derribada", muito provavelmente também alguns dos outros grupos identificados na Beira Alta, deve ser compreendida no âmbito desta diversidade, que umas vezes se justificará por aspectos intrínsecos das comunidades (extensão e organização interna, nível tecnológico, contacto com outras sociedades, etc., em estreita conexão, para além de outros factores, com a natureza física e potencialidades do território), outras, com o cerimonial, que pode ser diverso e repartido por diferentes construções, de acordo com as circunstâncias específicas de cada acto simbólico-religioso, traduzindo-se na fossa que apenas contém terra carbonosa e cinzas, ou a fossa que guardou quatro vasos cerâmicos, hermeticamente fechada com laje insculturada, funcionando como depósito votivo.

Só a prossecução do projecto permitirá avaliar mais aturadamente o significado da variabilidade, externa e interna destes tumuli, como dos gestos rituais, ao nível local e regional ("Casinha Derribada", "Fonte da Malga", "Mazugueira" e "Caramêlo", "Senhora da Ouvida", "Paranho", etc.) que, para além daquelas e outras variáveis poderão também passar pela cronologia das próprias construções.

Coimbra, Dezembro de 1997.

Conimbriga, 37 (1998), 5-76 


\section{Agradecimentos}

À Fundação Calouste Gulbenkian, Instituto Português do Património Arquitectónico e Arqueológico e Câmara Municipal de Viseu, que prestaram apoio económico e logístico, umas vezes ao projecto, outras aos trabalhos de campo e estudos complementares específicos.

Os Drs. João Manuel Abrunhosa e A. A. Huet Bacelar Gonçalves, da Faculdade de Ciências do Porto, ajudaram-nos, como em tantas outras vezes, no tratamento gráfico da informação topográfica. Crisanda T. Unsworth tem colaborado em vários aspectos do projecto; a versão inglesa do resumo deste texto é da sua autoria. Estamos-lhes gratos.

Uma primeira versão do original foi lida pelos Doutores Jorge Alarcão e Raquel Vilaça. Agradecemos-lhes a gentileza, bem como as correcções e sugestões; as imprecisões e as interpretações com que, eventualmente, não se identifiquem, são da nossa responsabilidade.

\section{BIBLIOGRAFIA}

Alarcão, J. de (1993), Arqueologia da Serra da Estrela, Manteigas, Parque Natural da Serra da Estrela.

Alarcão, J. de (1996 a), "As origens do povoamento da região de Viseu", Conimbriga, XXXV, pp. 5-36, 7 extra-textos.

Alarcão, J. de (1996 b), "O primeiro milénio a. C.", in De Ulisses a Viriato. O primeiro milénio a. C., Lisboa, Ministério da Cultura / Instituto Português de Museus / Museu Nacional de Arqueologia, pp. 15-30.

Almeida, C. A. B. (1990), Arqueologia do Concelho de Esposende, Câmara Municipal de Esposende, 1990 (prospecto).

Amo y de la Hera, M. del (1975 a), "Nuevas aportaciones para el estudio de la Edad del Bronce en el Suroeste peninsular: los enterramientos en cista de la provincia de Huelva", in XIII Congreso Nacional de Arqueología, Zaragoza, 1975, pp. 433-454.

Amo y de la Hera, M. del (1975 b), "Enterramientos en cistas de la provincia de Huelva”, in Huelva. Prehistoria y Antigüedad [cap. Ill, 2], Madrid, Editora Nacional, pp. 109-192.

Armbruster, B.; Parreira, R. (1993), Inventário do Museu de Nacional de Arqueologia. Colecção de ourivesaria. $l .{ }^{\circ}$ volume. Do Calcolitico à Idade do Bronze, Lisboa, SEC/IPM.

Conimbriga, 37 (1998), 5-76 
Ataíde, A.; Teixeira, C. (1940), “A necrópole e o esqueleto de S. Paio de Antas e o problema dos vasos de largo bordo horizontal", in Congresso do Mundo Português, vol. I, Lisboa, pp. 236-241.

Aubet Semmler, M. (1981), "Sepulturas de la Edad del Bronce en la Mesa de Setefilla (Sevilla)", Madrider Mitteilungen, 22, pp. 127-149.

Aubet Semmler, M. E.; Sema, M. R.; Escacena, J. L.; Ruiz Delgado, M. M. (1983), La Mesa de Setefilla. Lora del Rio (Sevilla). Campaña de 1979, Madrid, Ministerio da Cultura ["Excavaciones Arqueológicas en España", vol. 122].

Bettencourt, A. M. (1995), "O povoado da Santinha (Amares - Braga)", in $A$ Idade do Bronze em Portugal. Discursos de poder, Lisboa, SEC/IPM/ MNA, pp. 60-61.

Brandão, D. P. (1963), “Achados da "Época do Bronze” de Vila Cova de Perrinho, Vale de Cambra", Lucerna, III, Porto, pp. 114-118.

Cardoso, J. L.; Caninas, J. C.; Henriques, F. (1997), "Estruturas 1 e 2 do Monte de S. Domingos", in [Vilaça, 1997], pp. 14-16.

Cardozo, M. (1936), "Novas umas de largo bordo horizontal, um tipo de cerâmica primitiva", Trabalhos da Sociedade Portuguesa de Antropologia e Etnologia, 8 (1), Porto, pp. 65-87.

Carreira, J. R. (1994), “A Pré-história recente do Abrigo Grande das Bocas (Rio Maior)", Trabalhos de Arqueologia da EAM, 2, Lisboa, Colibri, pp. 47-144.

Castro Pérez, L. (1997), "Brazalete de bronce de Santo Tirso", Santo Tirso Arqueológico, 2. ${ }^{\text {a }}$ série, n. ${ }^{\circ}$ 1, Câmara Municipal de St. ${ }^{\circ}$ Tirso / Museu Municipal Abade Pedrosa, pp. 5-11.

Coelho, J. (1925), A Necrópole do Paranho, Viseu, Tipografia Popular [“Estudos Preistóricos", III].

Coelho, J. (1941) Beira histórica, arqueológica e artística. Memorias de Viseu (Arredores). I. A freguesia do Salvador e o extinto concelho do Barreiro e notas toponímicas de Viseu e concelhos limitrofes, Edição do Autor [Tipografia Notícias de Viseu].

Coelho, J. (1949), Notas Arqueológicas. Subsídios para o estudo etnológico da Beira, Viseu, Edição do Autor.

Costas Gobema, J.; Fernandez Pintos, J. (1985-86), "Diseños cuadrangulares a modo de tableros de juegos en los petroglifos del NW de la Península Ibérica", Pontevedra Arqueológica, II, 127-144.

Costas Gobema, F. J.; Novoa Álvarez, P. (1993), Los Grabados rupestres de Galicia, A Coruña ["Monografias Museu Arqueológico e Histórico A Coruña", n. $\left.{ }^{\circ} 6\right]$.

Conimbriga, 37 (1998), 5-76 
Cruz, D. J. (1991), A Mamoa 1 de Chã de Carvalhal no contexto arqueológico da Serra da Aboboreira e da Pré-história recente do Norte de Portugal, Coimbra (provas de aptidão pedagógica e capacidade científica, policopiado).

Cruz, D. J. (1997a), “A Necrópole do Bronze Final do "Paranho" (Molelos, Tondela, Viseu)", Estudos Pré-históricos, 5, Viseu, pp. 85-109,1 est.

Cruz, D. J. (1997b) (coord.), Colóquio a Pré-história na Beira Interior (Tondela, 21 a 23 de Novembro de 1997). Livro do Colóquio, Tondela, Centro de Estudos Pré-históricos da Beira Alta, 1997.

Fabián Garcia, J. F. (1995), El Aspecto Funerário durante el Calcolitico y los Inícios de La Edad del Bronce en la Meseta Norte, Salamanca, Universidad de Salamanca [“Acta Salmanticensia”, voi. 93].

Fábregas Valcarce, R. (1991), Megalitismo del Noroeste de la Península Ibérica. Tipología y secuencia de los materiales Uticos, Madrid, UNED.

Fábregas Valcarce, R. (1993), "Cistas decoradas y petroglifos: una revisión”, in Actas del XXII Congreso Nacional de Arqueología (Vigo, 7995), voi. II, Vigo, pp. 105-110.

Fernández Gomez, F.; Ruiz Mata, D.; Sancha Fernández, S. (1976), “Los enterramientos en cistas del Cortijo de Chichina (Sanlúcar la Mayor, Sevilla)", Trabajos de Prehistoria, n. s., 33, pp. 351-380, VI ests.

Ferreira, A. Brum (1978), Planaltos e montanhas do Norte da Beira. Estudo de geomorfologia, Lisboa ["Memórias do Centro de Estudos Geográficos", vol. 4]

Figueiral, I. (1997), "Necrópole do Paranho (Freg. de Molelos, Tondela). Resultados da análise dos carvões vegetais", Estudos Pré-históricos, 5, Viseu, pp. 121-122.

Fortes, J. (1905-08 a), "Duas joias archaicas", Portugalia, vol. II, Porto, pp. 412-416.

Fortes, J. (1905-08 b), "Vasos em forma de chapéu invertido (Vila do Conde)", Portugalia, vol. II, Porto, pp. 662-665.

Fortes, J. (1906), “A sepultura da Quinta da Água Branca (Edade do Cobre)”, Portugalia, vol. II, Porto, pp. 241-252.

Fortes, J. (1907), “A propos des sculptures sur les mégalithes du Portugal”, in Deuxième Congrès Préhistorique de France (Session de Vannes, 1906), Le Mans, Imprimerie Monnoyer. (Separata, 5 pp.).

Girão, A. A. (1921-22), "Monumentos pré-históricos do concelho de Viseu”, $O$ Arqueólogo Português, 1. ${ }^{\mathrm{a}}$ série, 25, Lisboa, pp. 183-189.

Gomes, M. V; Gomes, R. V; Beirão, C. M.; Matos, J. L. (1986), A Necrópole da Vinha do Casão (Vilamoura, Algarve) no contexto da Idade do

Conimbriga, 37 (1998), 5-76 
Bronze do Sudoeste Peninsular, Lisboa, IPPC ["Trabalhos de Arqueologia", vol. II].

Hedges, R. E. M.; Housley, R. A.; Bronk, C. R.; Klinken, G. J. van (1990), "Radiocarbon dates from the Oxford AMS system: Archaeometry Datelist 11 ", Archaeometry, 32 (2), Oxford, pp. 211-237.

Jorge, S. O. (1980), “A estação arqueológica do Tapado da Caldeira. Baião", Portugalia, n. s., I, Porto, pp. 29-50, XXII ests.

Jorge, S. O. (1983), "Duas datas de C14 para a sepultura I da estação do Tapado da Caldeira (Baião)", Arqueologia, 8, Porto, pp. 55-56.

Jorge, S. O. (1985), "Datas de Carbono 14 para a Pré-história recente do Norte de Portugal: os dados e os problemas", Arqueologia, 12, Porto, pp. 154-183.

Jorge, S. O. (1986), Povoados da Pré-história Recente da Região de Chaves - Va $P^{a}$ de Aguiar, Porto, Instituto de Arqueologia da Faculdade de Letras do Porto, 3 vols, (dissertação de doutoramento).

Jorge, S. O. (1988), O povoado da Bouça do Frade (Baião) no quadro do Bronze Final do Norte de Portugal, Porto, Grupo de Estudos Arqueológicos do Porto ["Monografias Arqueológicas", voi. 2].

Jorge, V. O.; Gonçalves, A. A. H.; Jorge, S. O. (1980), “As fossas ovoides abertas no saibro do concelho de Baião (distrito do Porto), e o seu significado no contexto da Arqueologia do Norte da Península Ibérica", in Actas do Seminário de Arqueologia do Noroeste Peninsular, vol. I, Guimarães, pp. 133-144.

Kalb, P. (1974-77), "Uma data de C-14 para o Bronze Atlântico", O Arqueólogo Português, 3. a série, vol. 7-9, Lisboa, pp. 141-144.

Kalb, P. (1978), "Senhora da Guia, Baiões. Die Ausgrabingen 1977 auf einer Höhensieddlung der Atlantischen Bronzezeit in Portugal", Madrider Mitteilungen, 19, pp. 112-138.

Kalb, P. (1980), “Zur Atlantischen Bronzezeit in Portugal”, Germania, 58, Mainz, pp. 25-59.

Kalb, P. (1993), "Reflexões sobre a utilização de necrópoles megalíticas na Idade do Bronze", Estudos Pré-históricos, 2, Viseu, pp. 415-426.

Kalb, R; Höck, M. (1979), "Escavações na necrópole de mamoas "Fonte da Malga" - Viseu, Portugal", Beira Alta, 38 (3), Viseu, pp. 593-604, XV Est.

Kalb, R; Höck, M. (1980), “Ausgrabungen in der Grabhügelnekropole "Fonte da Malga" (Viseu, Portugal)”, Madrider Mitteilungen, 20, pp. 43-55.

Kalb, R; Höck, M. (1981-82), “Cabeço da Bruxa, Alpiarça (distrito de Santarém). Relatório preliminar da escavação de Janeiro e Fevereiro de 1979”,

Conimbriga, 37 (1998), 5-76 
Portugalia, n. s., voi. II/III, pp. 61-69, XIII ests.

Kalb, R; Höck, M. (1985 a), Cerâmica de Alpiarça. Exposição temporária na Galería dos Patudos. Catálogo, Alpiarça, Câmara Municipal de Alpiarça - Casa Museu dos Patudos / Instituto Arqueológico Alemão.

Kalb, R; Höck, M. (1985 b), Cerâmica da Senhora da Guia, Baiões e peças comparáveis do Sul de Portugal na exposição ${ }^{\prime C}$ Cerâmica de Alpiarça Suplemento ao Catálogo, Viseu, Grupo de Amigos do Museu de Grão Vasco / Instituto Arqueológico Alemão.

Leisner, V. (1958), "Nota sobre um vaso transmontano", Arqueologia e História, 8. a série, voi. Ill, Lisboa, pp. 145-153.

Linick, T. W.; Long, A.; Damon, P. E.; Ferguson, C. W. (1986), "High-precision radiocarbon dating of bristlecone pine from 6554 to 5350 BC", Radiocarbon, 28, pp. 943-953.

López Cuevillas, F. (1930), "Novas cerámicas das antas galegas", Trabalhos da Sociedade Portuguesa de Antropologia e Etnologia, vol. IV (3), Porto, pp. 280-281.

López Cuevillas, F. (1980), "Prehistoria" in Historia de Galiza (dir. de R. Otero Pedrayo), vol. Ill, com Adenda e Corrigenda de X. Taboada Chivite, Madrid, Akal, Editor.

López Cuevillas, F.; Bouza Brey, F. (1929), Os Oestrimnios, os Saefes e a Ofilatria en Galiza, A Cruña ["Arquivos do Seminario d'Estudos Galegos", vol. II].

López Cuevillas, F; Bouza Brey, F. (1931), "La civilisación neo-eneolítica gallega", Arquivo Español de Arte e Arqueologia, n. ${ }^{\circ}$ 19, Madrid, p. 10 e ss.

López Cuevillas, F; Lourenzo Fernández, X. (1930), Vila de Calvos de Randin. Notas etnográficas e folklóricas, Santiago de Compostela ["Seminàrio de Estudos Galegos"].

Luengo Martínez, J. M. (1965), "Las sepulturas de la Edad del Bronce descubiertas en Camota", La Voz de Galicia, 21 de mayo de 1965.

Marques, G. (1972), Arqueologia de Alpiarça. As estações representadas no Museu do Instituto de Antropologia do Porto, "Trabalhos do Instituto de Antropologia "Dr. Mendes Corrêa"", n. ${ }^{\circ}$ 13, Porto.

Marques, G.; Andrade, G. M. (1974), “Aspectos da proto-história do território português. 1 - Definição e distribuição geográfica da cultura de Alpiarça (Idade do Ferro)", in Actas do III Congresso Nacional de Arqueologia, vol. I, Porto, pp. 125-148.

Martins, M. M. R. (1987), O povoamento proto-histórico e a romanização da bacia do curso médio do Cávado, Braga, Universidade do Minho, 3

Conimbriga, 37 (1998), 5-76 
vols, (dissertação de doutoramento, policopiada).

Meijide Cameselle, G. (1993), "La necropolis del Bronce inicial del Agro de Nogueira (Toques, A Coruña)", Actas del XXII Congreso Nacional de Arqueología, Vigo, pp. 85-88.

Meijide Cameselle, G. (1996), "La necrópolis del Bronce inicial del Agro de Nogueira (Piñeiro, Toques, A Coruña) en el contexto funerario de su época", Humanitas. Estudios en Homenaxe ó Prof. Dr. Carlos Alonso del Real, vol. I, Universidade de Santiago de Compostela, pp. 215-239.

Moita, I. (1966), "Características predominantes do grupo dolménico da Beira Alta", Ethnos, 5, Lisboa, pp. 189-277, XX ests., 1 mapa extra-texto.

Monteagudo, L. (1977), Die Beile auf der Iberischen Halbinsel, München ["Prähistorische Bronzefunde", IX, band 6].

Monteagudo, L.; García Alén, A.; Lois Mejomil, J. (1981), "El hacha de salto (Rodeiro) y las primeras hachas de tope de dos asas en Europa", El Museo de Pontevedra, vol. XXXV, pp. 117-162.

Paço, A. (1933), "Vaso de bordo horizontal, de Vila Fria", in Homenagem a Martins Sarmento, Guimarães, Sociedade Martins Sarnento, pp. 272-276.

Pearson, G. W.; Becker, B.; Qua, F. (1993), "High-precision ${ }^{14} \mathrm{C}$ measurement of german and irish oaks to show the natural ${ }^{14} \mathrm{C}$ variations from 7890 to 5000 BC", Radiocarbon, 35, pp. 93-104.

Pearson, G. W.; Stuiver, M. (1993), "High-precision bidecadal calibration of the radiocarbon time scale, 500-2500 BC", Radiocarbon, 35, pp. 25-33.

Pedro, I. (1995), O povoamento proto-histórico na região de Viseu, Porto (dissertação de mestrado, policopiada).

Peña Santos, A. de la (1985), "Las cistas de Gandón (Cangas de Morrazo, Pontevedra)", El Museo de Pontevedra, XXXIX, pp. 79-94.

Queiroga, F. M. V. R.; Figueiral, I. M. A. C. R. (1992), "Datações de Carbono 14 para Castelo de Matos", Boletim Cultural. Câmara Municipal de Vila Nova de Famalicão, 9, pp. 67-69.

Ramil Soneira, J.; Vázquez Varela, J. M. (1979), "Enterramientos en cista de la Edad del Bronce de "O Cubillón", Xermade (Lugo)", El Museu de Pontevedra, XXXIII, pp. 63-68.

Rodríguez Casal, A. A. (1989), La necropolis megalitica de Parxubeira (San Fins de Eirón, Galicia). Campañas arqueológicas de 1977 a 1984, $A$ Coruña ["Monografías urxentes do Museu", n. $\left.{ }^{\circ} 4\right]$.

Ruiz-Gálvez Priego, M. (1979), "El Bronce Antiguo en la fachada atlántica peninsular: un ensayo de periodización”, Trabajos de Prehistoria, voi. 36, Madrid, pp. 151-172.

Conimbriga, 37 (1998), 5-76 
Sanches, M. J. (1982), "Vasos da estação do Corvilho - St. ${ }^{\circ}$ Tirso", Arqueologia, 5, Porto, pp. 56-61.

Sanches, M. J. (1995), "O povoado da Lavra, Serra da Aboboreira”, in A Idade do Bronze em Portugal. Discursos de poder, Lisboa, SEC/IPM/MNA, p. 116.

Santarém, C. M. F. (1956), “Algumas peças inéditas do Museu Abade Pedrosa”, O Concelho de Santo Tirso. Boletim Cultural, vol. IV, n. ${ }^{\circ}$ 2, pp. 169-177, 2 extra-textos.

Santos, M. R; Soares, J.; Silva, C. T. (1974), "Necrópole da Pro vença (Sines)”, Arqueologia e História, vol. V, pp. 69-99.

Sarmento, F Martins (1933), Dispersos, Coimbra, Imprensa da Universidade.

Schubart, H. (1965), "Atalaia, uma necrópole da Idade do Bronze no Baixo Alentejo”, Arquivo de Beja, vol. XXII, pp. 7-136.

Schubart, H. (1971), “Acerca de la ceràmica del Bronce tardío en el Sur y Oeste de la Península Ibérica", Trabajos de Prehistoria, vol. 28, pp. 153 e ss.

Schubart, H. (1974), "La cultura del Bronce en el sudoeste peninsular. Distribución y definición", in Miscelánea Arqueológica, Barcelona, vol. II, pp. 345-370.

Schubart, H. (1975), Die Kultur der Bronzezeit im Südwesten der Iberischen Halbinsel Berlim, Walter de Gruyter \& Co. ["Madrider Forschungen", voi. 9].

Senna Martinez, J. C. (1989), Pré-história recente da bacia do Médio e Alto Mondego. Algumas contribuições para um modelo sociocultural Lisboa, Faculdade de Letras da Universidade de Lisboa, 2 vols, (dissertação de doutoramento, policopiada).

Senna Martinez, J. C. (1991), "The Late Prehistory of Central Portugal: a first diacronie view", in K. T. Lillios (ed.), The origins of complex societies in Late Prehistoric Iberia, Chicago ["International Monographs in Prehistory"].

Senna Martinez, J. C. (1993), “O Grupo Baiões/Santa Luzia: contribuições para uma tipologia da olaria", Trabalhos de Arqueologia da EAM, 1, Lisboa, Colibri, pp. 93-123.

Senna Martinez, J. C.; Valera, A. C. N.; Teixeira, C.; Ventura, J. M. Q. (1993), "A ocupação do Bronze Final da "Sala 20" do Buraco da Moura de São Romão", Trabalhos de Arqueologia da EAM, 1, Lisboa, Colibri, pp. $125-135$.

Silva, A. C. F. (1985), “As fossas ovoides de Beiriz e a problemática das práticas funerárias no final da Idade do Bronze", Actas do Colóquio "Santos Graça " de Etnografia Maritima, voi. Ill (Povoamento e Administração

Conimbriga, 37 (1998), 5-76 
- Aspectos sociais), pp. 13-20.

Silva, A. C. F. (1986), A Cultura Castreja no Noroeste de Portugal, Paços de Ferreira, Câmara Municipal de Paços de Ferreira / Museu Arqueológico da Citânia de Sanfins.

Silva, A. C. F; Raposo, L.; Silva, C. T. (1993), Pré-história de Portugal, Lisboa, Universidade Aberta.

Silva, A. M.; Cunha, E. (1997), “As incinerações da necrópole do Paranho: abordagem antropológica”, Estudos Pré-históricos, 5, Viseu, pp. 111-119.

Silva, Celso T. (1978 a), "Cerâmica típica da Beira Alta", in Actas das III Jornadas Arqueológicas (Lisboa, 13 de Outubro de 1977), Lisboa, Associação dos Arqueólogos Portugueses, voi. I, pp. 185-191, IV ests.

Silva, Celso T. (1978 b), "Gravuras rupestres inéditas da Beira Alta", in Actas das III Jornadas Arqueológicas. 1977, voi. I, Lisboa, Associação dos Arqueólogos Portugueses, pp. 165-184.

Silva, Celso T. (1980), “As Gravuras rupestres de Lufinha. Dois motivos labirínticos na região de Viseu", in Actas do Seminário de Arqueologia do Noroeste Peninsular, vol. II, Guimarães, Sociedade Martins Sarmento, pp. 155-169, IV ests.

Silva, Celso T. (1989), "Gravuras rupestres de Ferronhe (Viseu)", in Actas do I Coloquio Arqueológico de Viseu, Viseu, Governo Civil do Distrito de Viseu, pp. 283-288.

Silva, Carlos T.; Soares, J. (1981), Pré-história da Área de Sines — Trabalhos Arqueológicos de 1972-77, Gabinete da Area de Sines, Lisboa.

Silva, E. J. L. (1994), "Megalitismo do Norte de Portugal: o litoral minhoto", Estudos Pré-históricos, 2, Viseu, pp. 157-169, III ests. [“Actas do Seminário "O Megalitismo no Centro de Portugal"].

Silva, F. A. P. (1989), "Escavação da mamoa 4 de Alagoas (Escariz — Arouca). 1987-1988”, Trabalhos de Antropologia e Etnologia, XXIX, Porto, pp. 47-71.

Soeiro, T. (1988), “A propósito de quatro necrópoles proto-históricas do concelho de Esposende", in Actas do Colóquio "Manuel de Boaventura" -1985

- Arqueologia, Esposende, Câmara Municipal de Esposende, pp. 35-62.

Stuiver, M.; Pearson, G. W. (1993) "High-precision bidecadal calibration of the radiocarbon time scale, AD 1950-500 BC and 2500-6000 BC", Radiocarbon, 35, pp. 1-23.

Stuiver, M.; Reimer, P. J. (1993), "Extended ${ }^{14} \mathrm{C}$ database and revised CALIB radiocarbon calibration program", Radiocarbon, 35, pp. 215-230.

Conimbriga, 37 (1998), 5-76 
Vasconcellos, J. L. (1908), "Estudos sobre a época do bronze em Portugal”, $O$ Archeologo Português, vol. XIII, Lisboa, pp. 300-313.

Vaz, J. L. I. (1993), A civitas de Viseu (Espaço e sociedade), Coimbra (dissertação de doutoramento).

Vázquez Rosas, R. (1997), Petro glifos de las rias baixas gallegas. Análisis artístico de un arte prehistórico, Pontevedra, Servicio de publicacións Excm. ${ }^{\text {a }}$ Deputación Provincial de Pontevedra.

Vázquez Varela, J. M. (1979), "El horizonte de Rechaba: una nueva fase de la cultura megalítica del Noroeste peninsular", Boletín Auriense, 9, Ourense, pp. 9-26.

Vázquez Varela, J. M. (1980a), "Cistas decoradas en Galicia: una nueva manifestación artística de la Edad del Bronce", Brigantium, 1, La Coruña, pp. 41-48. 


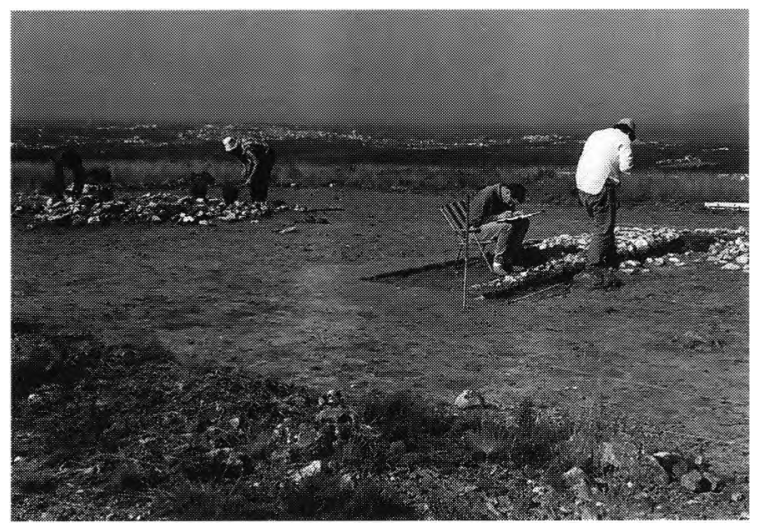

Fото 1 - Aspecto dos monumentos 3 e 4 da "Casinha Derribada", obs. aprox. de NE. Ao fundo, o aglomerado urbano de Viseu.

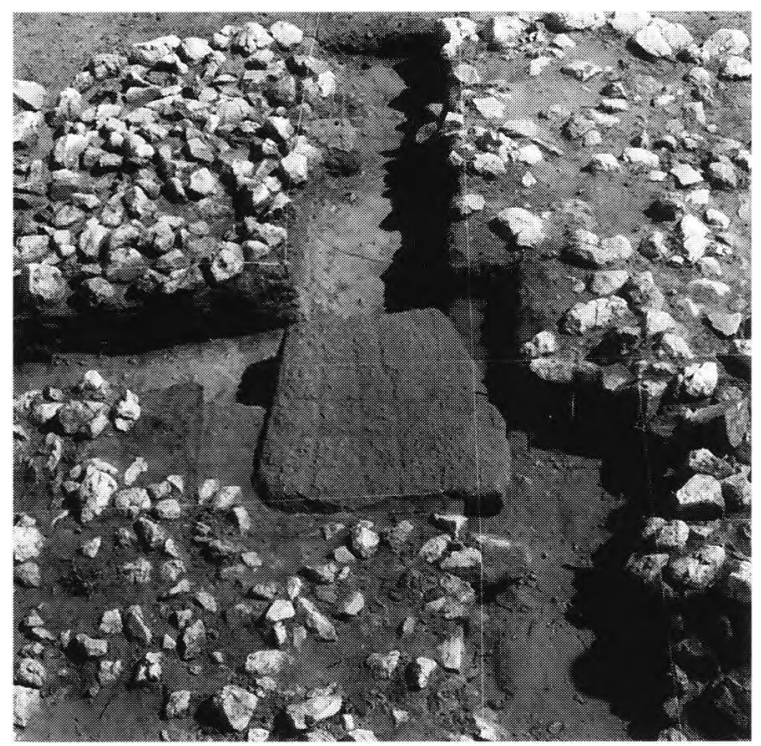

FOTо 2 - Laje de cobertura da fossa do monumento 3. Obs. de norte. 


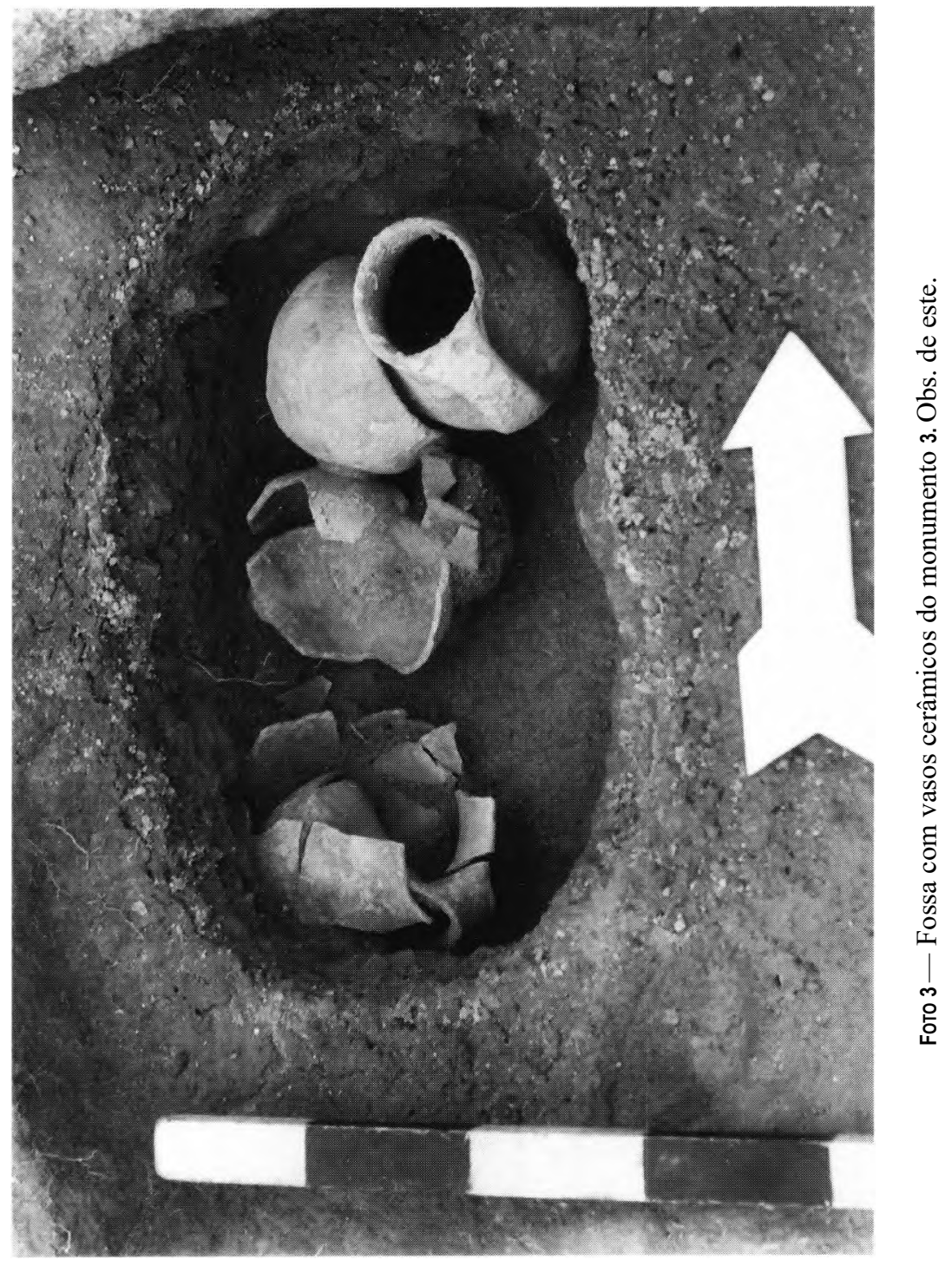




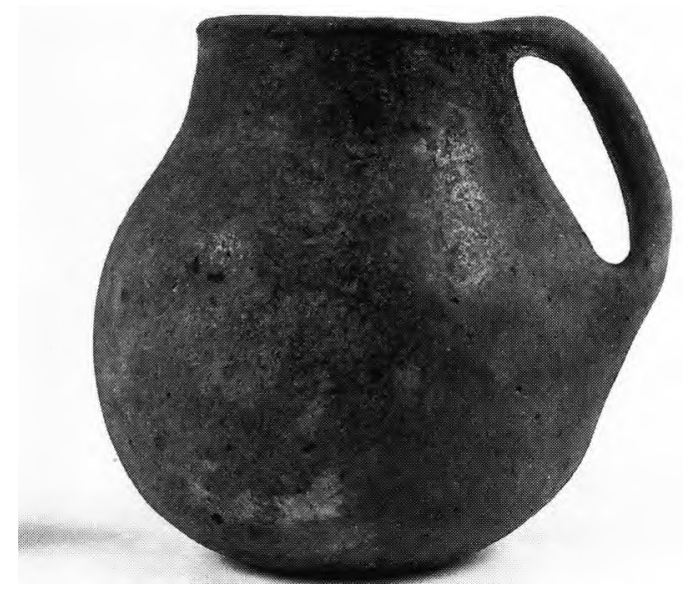

Fото 4 - Vaso cerâmico - ovòide com colo alto, troncoconico, fechado. Monumento 3 da "Casinha Derribada". Foto de A. Roldão

(I.C.B.A.S., Universidade do Porto).

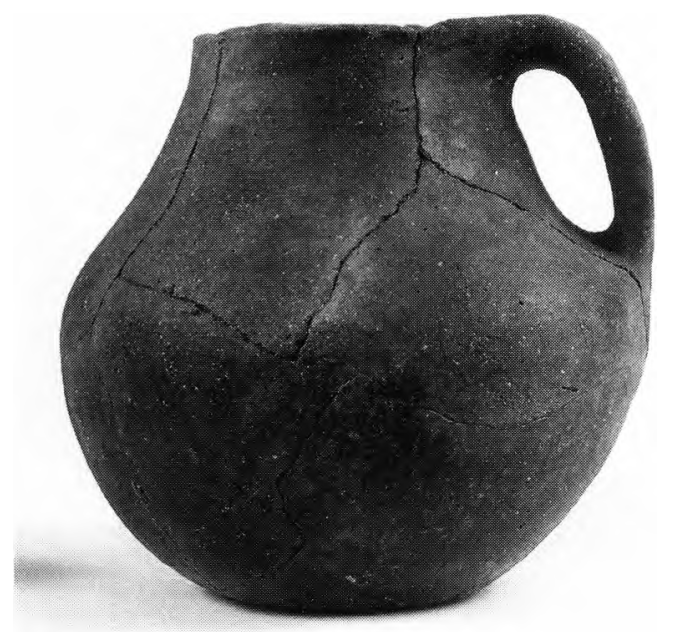

Fото 5 - Vaso ceràmico - ovoide com colo alto, troncoconico, muito inclinado, fechado. Monumento 3 da "Casinha Derribada". Foto de A. Roldão (I.C.B.A.S., Universidade do Porto). 


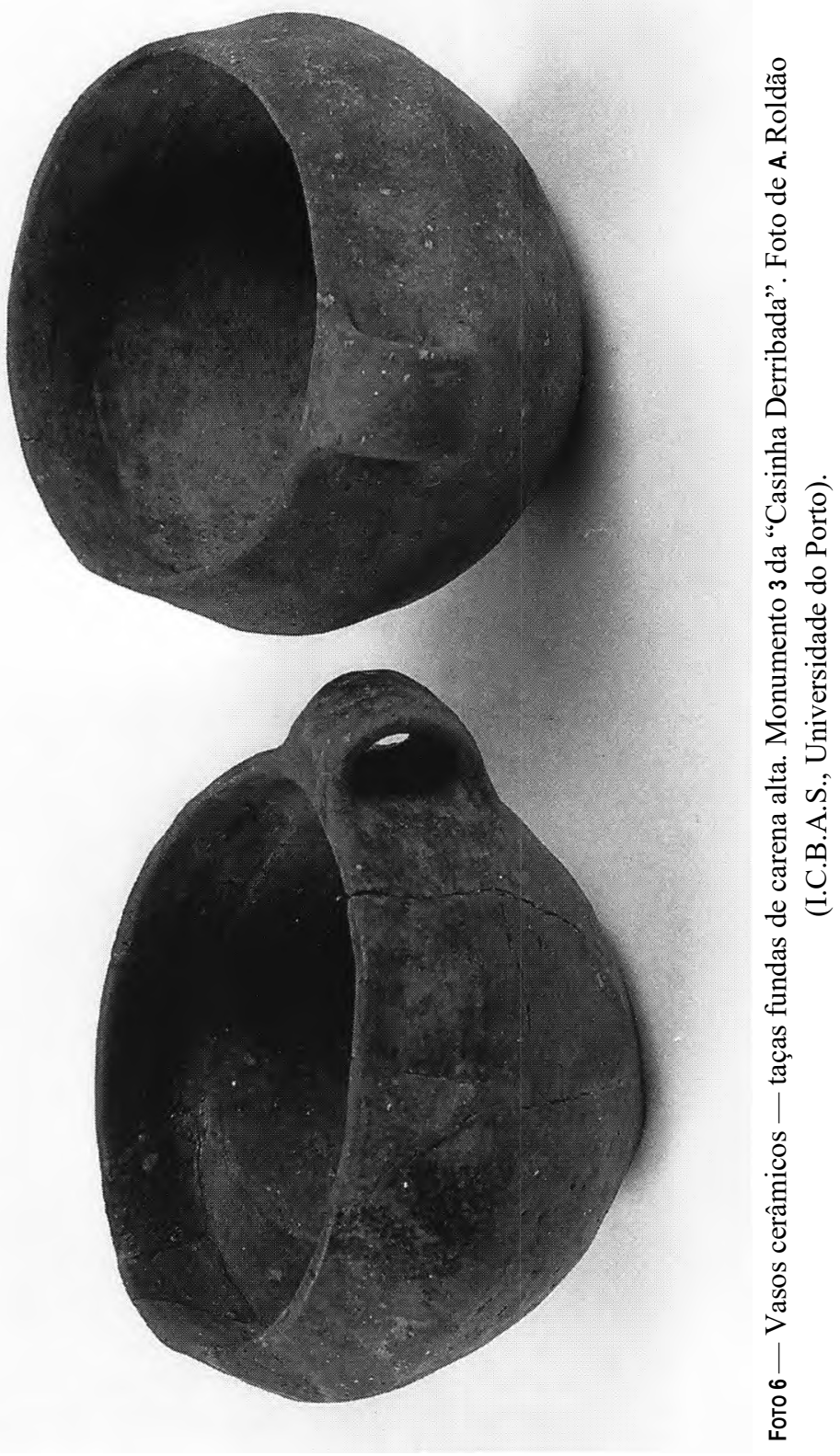




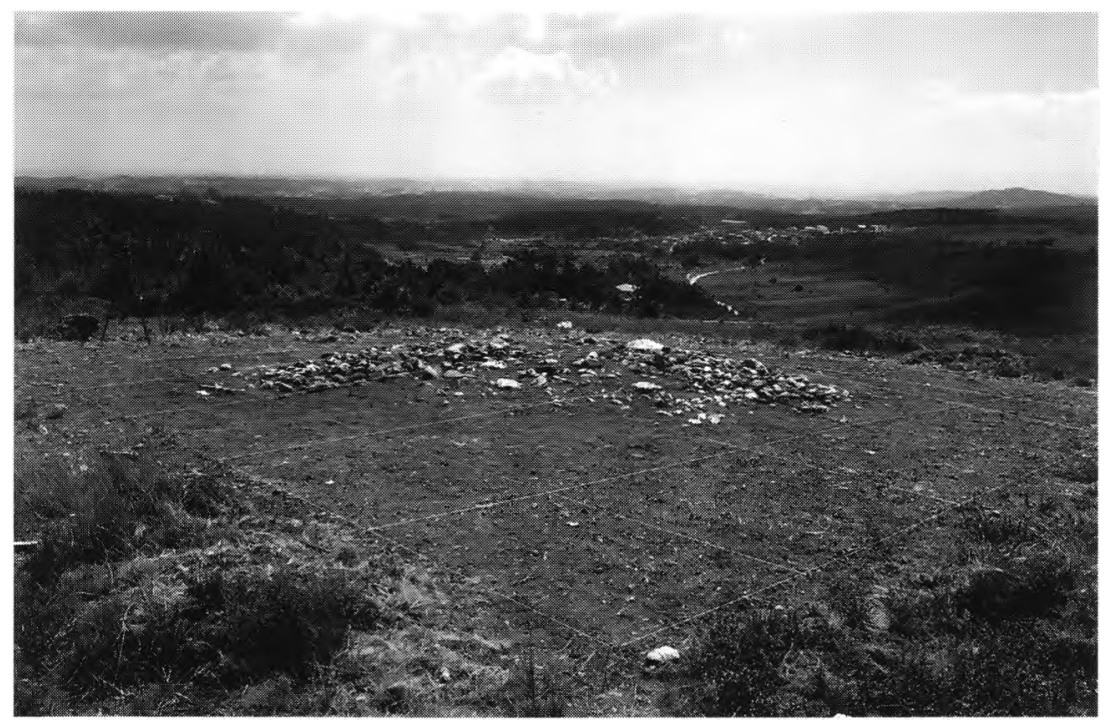

Fото 7 - Monumento 5 da "Casinha Derribada", obs. de NE. Em primeiro plano avistam-se as primeiras casas de Póvoa de Mundão e o amplo vale do

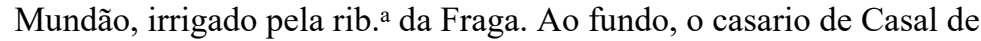
Mundão e, em último plano, à direita, o Monte de St. ${ }^{\mathrm{a}}$ Luzia.

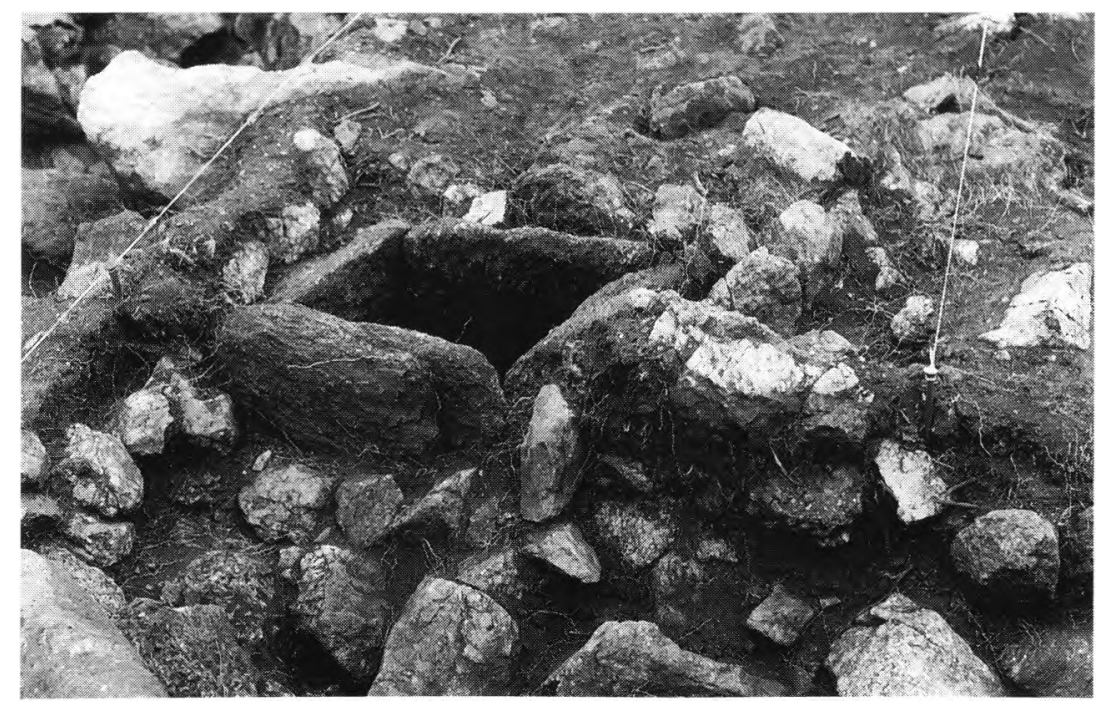

Fото 8 - A cista do monumento 5 da "Casinha Derribada".

Obs. aprox. de SE. 